\title{
Landscape transformations at the dawn of agriculture in southern Syria (10.7-9.9 ka cal. BP): plant-specific responses to the impact of human activities and climate change
}

Article

Accepted Version

Arranz-Otaegui, A., López-Sáez, J. A., Araus, J. L., Portillo, M., Balbo, A., Iriarte, E., Gourichon, L., Braemer, F., Zapata, L. and Ibáñez, J. J. (2017) Landscape transformations at the dawn of agriculture in southern Syria (10.7-9.9 ka cal. BP): plant-specific responses to the impact of human activities and climate change. Quaternary Science Reviews, 158. pp. 145163. ISSN 02773791 doi:

https://doi.org/10.1016/j.quascirev.2017.01.001 Available at https://centaur.reading.ac.uk/69058/

It is advisable to refer to the publisher's version if you intend to cite from the work. See Guidance on citing.

Published version at: http://dx.doi.org/10.1016/j.quascirev.2017.01.001

To link to this article DOI: http://dx.doi.org/10.1016/j.quascirev.2017.01.001

Publisher: Elsevier

All outputs in CentAUR are protected by Intellectual Property Rights law, 
including copyright law. Copyright and IPR is retained by the creators or other copyright holders. Terms and conditions for use of this material are defined in the End User Agreement.

\section{www.reading.ac.uk/centaur}

\section{CentAUR}

Central Archive at the University of Reading

Reading's research outputs online 
1 Landscape transformations at the dawn of agriculture in southern Syria (10.7-9.9 ka

2 cal. BP): Plant-specific responses to the impact of human activities and climate 3 change

4

5 Amaia Arranz-Otaegui, ${ }^{1}$ José Antonio López-Sáez, ${ }^{2}$ José Luis Araus, ${ }^{3}$ Marta Portillo,, 4

6 Andrea Balbo, ${ }^{6}$ Eneko Iriarte, ${ }^{7}$ Lionel Gourichon, ${ }^{8}$ Frank Braemer, ${ }^{8}$ Lydia Zapata, ${ }^{4}$ Juan

7 José Ibáñez, ${ }^{9}$

8

$9 \quad{ }^{1}$ Department of Cross-Cultural and Regional Studies, University of Copenhagen, Denmark

${ }^{2}$ Research Group ‘Archaeobiology', Institute of History, CSIC, Madrid, Spain

$11{ }^{3}$ Section of Plant Physiology, Faculty of Biology, Universitat de Barcelona, Barcelona,

12 Spain

$13{ }^{4}$ Department of Geography, Prehistory and Archaeology, University of the Basque

14 Country, Vitoria-Gasteiz, Spain

$15{ }^{5}$ Department of Archaeology, University of Reading, Reading RG6 6AB, UK

${ }^{6}$ Climate Change and Security (CLISEC), Center for Earth System Research and

Sustainability (CEN), University of Hamburg, D-20144 Hamburg, Germany

${ }^{7}$ Universidad de Burgos, Laboratorio de Evolución Humana, Burgos, Spain

${ }^{8}$ Université Côte d'Azur, CNRS, CEPAM, France

${ }^{9}$ Institució Milà i Fontanals, CSIC, Barcelona, Spain

Corresponding author:

Amaia Arranz-Otaegui

kch860@hum.ku.dk 


\section{Abstract}

In southwest Asia, the accelerated impact of human activities on the landscape has often been linked to the development of fully agricultural societies during the middle and late Pre-Pottery Neolithic B (PPNB) period (around 10.2-7.9 ka cal. BP). This work contributes to the debate on the environmental impact of the so-called Neolitisation process by identifying the climatic and anthropogenic factors that contributed to change local and regional vegetation at the time when domesticated plants appear and developed in southern Syria (around 10.7-9.9 ka cal. BP). In this work an inter-disciplinary analyses of botanical microremains (pollen and phytoliths) and macroremains (wood charcoal) is carried out along with stable carbon isotope discrimination of wood charcoals in an early PPNB site (Tell Qarassa North, west of the Jabal al-Arab area). Prior to $10.5 \mathrm{ka}$ cal. BP, the results indicate a dynamic equilibrium in the local and regional vegetation, which comprised woodland-steppe, Mediterranean evergreen oak-woodlands, wetland vegetation and coniferous forests. Around 10.5-9.9 ka cal. BP, the elements that regulated the vegetation system changed, resulting in reduced proportions of arboreal cover and the spread of cold-tolerant and wetlands species. Our data show that a reinforcing interactions between the elements of the anthropogenic (e.g. herding, fire-related activities) and climatic systems (e.g. temperature, rainfall) contributed to the transformation of early Holocene vegetation during the emergence of fully agricultural societies in southern Syria.

\section{Keywords}

Palaeovegetation; Early Holocene; Climate change; Southwest Asia; Domestication; Archaeobotany; Anthropogenic impact

\section{Highlights}

- Multi-proxy analyses reveal diverse vegetation around 10.7-9.9 ka cal. BP.

- Cereals were domesticated in wetter conditions than at present in southern Syria.

- Dynamic equilibrium around 10.7-10.5 ka cal. BP, changes around 10.5-9.9 ka cal. BP.

- RCCs as trigger for the expansion of cold-tolerant and wetland vegetation.

- Increased anthropogenic impacts and RCCs coincided with decreased arboreal cover. 


\section{Introduction}

The Pre-Pottery Neolithic (PPN) represents a key time period to understand the emergence of agriculture in southwest Asia. During the Pre-Pottery Neolithic A (PPNA, 11.6-10.7 ka cal. BP), there is evidence for the development of plant food production activities involving morphologically wild plant species (Willcox et al., 2008), along with the evidence of early control or management of wild animal populations (Ervynck et al., 2001; Vigne, 2013). Subsequently, during the early Pre-Pottery Neolithic B (EPPNB, 10.7$10.2 \mathrm{ka} \mathrm{cal}$. BP), the first morphologically domesticated plants (Tanno and Willcox, 2012) and animal species (Helmer et al., 2005; Peters et al. 2005; Zeder, 2011) appear in the archaeological record, yet the exploitation of morphologically wild species predominated during this time. Agriculture, defined as a subsistence system largely relying on domesticated resources (Zeder, 2015), evolved only around 10.2-9 ka cal. BP, during the middle and late PPNB (Asouti and Fuller, 2012, 2013; Zeder, 2011).

The environmental settings of the PPN period, exception made for the Khiamian period that developed within the last years of the Younger Dryas, were primarily those of the Preboreal climatic oscillations (Maher et al., 2011). This period was characterised by rapid warming, with increased mean yearly temperatures of about $7^{\circ} \mathrm{C}$ (Alley, 2000), combined with minimum rainfall rates in excess of $350 \mathrm{~mm} / \mathrm{yr}$, making it one of the wettest periods in Southwest Asia in the last 25,000 years (Robinson et al., 2006; Weninger et al., 2009). However, early Holocene climate was not stable, and several Rapid Climatic Changes (RCCs) occurred in the eastern Mediterranean at the time when agriculture developed in southwest Asia, c. 10.2 ka cal. BP (Mayewski et al., 2004; Weninger et al., 2009). Such RCCs comprised cold/dry (e.g. 10.2 and $8.2 \mathrm{ka} \mathrm{cal}$. BP) and wet/warm (Levantine Moist Period and Sapropel S1, 10.1-8.6 ka cal. BP) spells. Some of these events seem to have caused considerable changes in the vegetation. For example, maximum Pistacia percentages (the so-called "Pistacia Phase") were recorded during the Sapropel depositions (around 9-6 ka cal. BP) in several pollen diagrams from the Adriatic and Ionian Sea, Lake Ioannina and Lake Xinias (Greece), Tenaghi Phillippon (Greece), and Ghab (Syria) indicating relatively warm winters and mild summers (Rossignol-Strick 1995; 1999). Reductions in the proportions of evergreen Quercus were recorded shortly after the dry $8.2 \mathrm{ka}$ cal. BP event at Tenaghi Phillippon Greece (Pross et al., 2009). During the same time period in the Eastern Mediterranean (close to the Israel coast) pollen records from deep-sea cores indicate maximum values for dry-tolerant Artemisia (Laggunt et al., 2011). Yet, the understanding of the effects that early Holocene RCCs caused in the 
vegetation, and by extension, in the subsistence of the early agricultural groups during the Pre-Pottery Neolithic is still limited (Weninger et al., 2009; Flhor et al., 2016; Berger et al., 2016).

Despite the diverse bioclimatic regions and vegetation zones in southwest Asia (see a short summary in Asouti et al., 2015), the available pollen records indicate a consistent reduction in non-arboreal pollen (NAP) during the early Holocene, and an overall increase in arboreal pollen (AP), characterised, in particular, by the spread of woodland-steppe taxa (Pistacia and Amygdalus, pistachio and almond) and Quercus (oak) woodlands (van Zeist and Bottema, 1977; van Zeist and Woldring, 1978; Rossignol-Strick, 1993, 1995, 1997, 1999; Stevens et al., 2001, 2006; Wright and Thorpe, 2003; Wick et al., 2003; Rosen, 2007; Hajar et al., 2010; Rambeau, 2010). However, the time at which oak-woodlands developed across southwest Asia varied from one region to the other. In the Mediterranean area of the western Levant the spread of deciduous Quercus occurred 10.3-8.4 ka cal. BP (Wright and Thorpe, 2003; Rosen, 2007; van Zeist et al., 2009), whereas pollen records from the Irano-Anatolian region including southwest Iran (Zagros area) and central and eastern Anatolia point to a later expansion, around 7.5-4.5 ka cal. BP (Bottema and Woldring, 1984; van Zeist and Bottema, 1977; Stevens et al., 2001; Wick et al., 2003; Djamali et al., 2008; Litt et al., 2009).

Some argued that climatic conditions that would have allowed oak-woodland expansion did not develop in these areas until later (van Zeist and Bottema, 1991; Roberts and Wright, 1993; Rossignol-Strick, 1997). Yet, others have attributed this delay to anthropogenic factors. Several researchers proposed that increased wildfires at the beginning of the Holocene could have contributed to the development of grasslands in central and eastern Anatolia (considered as competitors for oak-seedlings), which would have hindered oak growth and expansion (Wick et al., 2003; Turner et al., 2010). Roberts (2002) suggested that the human activities that developed with the establishment of agriculture in southwest Asia (e.g. land clearance for crop cultivation, burning, animal grazing/browsing, and wood cutting for fuel and lime-plaster manufacture), besides a more marked seasonality and the intensified occurrence of wild fires during the early Holocene, were overall responsible for the late establishment of oak-woodlands in central-eastern Anatolia and the Zagros (see also Turner et al., 2010). Based on wood charcoal analyses, pollen records and observations on modern vegetation in central Anatolia, Asouti and Kabukcu (2014) suggested that semi-arid deciduous oak woodlands in this particular region evolved progressively, for around 3000 years, enhanced by several anthropogenic 
activities (i.e. selective exploitation of Rosaceae-Maloideae, light-moderate grazing by ruminants and managements of Quercus stands) carried out by M/LPPNB groups starting around 9-8 ka cal. BP. They argued that early Neolithic anthropogenic activities contributed to, rather than hampered, the spread of oak-woodland vegetation in the IranoAnatolian region, and they considered these low-diversity oak-dominated woodlands as one of the earliest anthropogenic vegetation types in southwest Asia.

Nevertheless, the type and scale of the impacts caused by human groups around $10.0 \mathrm{ka}$ cal. BP in southwest Asia was regionally diverse, probably as a consequence of the different environmental conditions and economic activities carried out by local human populations. In the Zagros area, increased proportions of Plantago lanceolata (English plantain) in the pollen records has been interpreted as evidence of highly disturbed habitats caused by fires set by local hunters and herders (van Zeist and Bottema, 1977; see also Wasylikowa et al., 2006). In the northern Levant (Ghab area, northwest Syria), Yasuda et al. (2000) recorded an increase of micro-charcoals and the decline of Quercus pollen around 10.1-9.5 ka cal. BP, interpreting it as the oldest evidence of large-scale anthropogenic forest clearance or deforestation (see Roberts, 2002 and Meadows, 2005, for an alternative interpretation of the data). In the southern Levant, several authors claimed that agricultural and lime production activities by PPNB groups in areas that nowadays receive low average rainfall for dry-farming (i.e. marginal areas) completely modified the pre-existing landscape and could have led to deforestation (Köhler-Rollefson 1988, Bar-Yosef, 1995; Rollefson 1990, Köhler-Rollefson and Rollefson, 1989, 1990). Yet, authors such as Blumler (2007) have put into questions that deforestation occurred during the early Holocene in Southwest Asia, since the re-examination of 13 primary pollen datasets from Greece, Turkey, Syria and Israel do not show strong reduction in arboreal cover during this time (e.g. from $90 \%$ to 30\%). This view is reinforced by pollen records in north-western Turkey and Northern Israel (Golan Heights), where anthropogenic activities (e.g. herding) were identified only during the Early Bronze Age (ca. 4.8 ka cal. BP) (Miebach et al. 2015; Schwab et al. 2004), and slightly later, around $3.8 \mathrm{ka}$ cal. BP, in the Lake Van (eastern Anatolia) (Wick et al., 2003). Asouti et al. (2015) proposed that far from causing degradation, anthropogenic activities could have enhanced woodland-expansion not only in the Irano-Anatolian region but also in the arid area of the southern Levant (e.g. Jordan Rift Valley). High proportions of Pistacia wood charcoal and nutshells found at Pre-Pottery Neolithic Wadi el-Hemmeh were interpreted as evidence for the intensive management of these trees as a source of food, fuel and fodder, and along 
with early Holocene climatic improvements, they would have contributed to the gradual expansion of Pistacia woodlands in the area (Asouti et al., 2015).

All perspectives considered, the degree to which early Holocene climate and Neolithic activities shaped local and regional vegetation in southwest Asia remains still an open question. There are as yet no enough data to address the effects of early Holocene RCC in the vegetation across southwest Asia, and depending on the author and the region under study, there are multiple views regarding the impact of Neolithic activities in the landscape (e.g. severe impacts in the form of deforestation, contribution to woodland expansion, no impact in the landscape until later periods). In addition to this, most of the studies so far have focused on the anthropogenic impacts of fully-fledged agricultural societies in southwest Asia (i.e. $10.2 \mathrm{ka}$ cal. BP onwards), and as a result, there is a significant lack of evidence to characterise the environmental setting and anthropogenic impacts that concern the period immediately preceding the emergence of agriculture (e.g. the PPNA and EPPNB, around 11.6-10.2 ka cal. BP), despite animal and plant management activities were already common practice during this time.

\section{Aims and scope}

In this study we focus on the local and regional setting of Tell Qarassa North, an EPPNB site located in southern Syria (west of the Jabal al-Arab area). The site was occupied around 10.7-9.9 ka cal. BP (Ibañez et al., 2010), the time at which morphologically domesticated plants first appear in southwest Asia (Tanno and Willcox, 2012; Arranz-Otaegui et al., 2016a). Tell Qarassa provides direct evidence from plant micro and macroremains found in archaeological context, correlated by micro and macrostratigraphic studies and radiocarbon dating (Ibañez et al., 2010b; Balbo et al., 2012; Santana et al., 2012, 2015; Arranz-Otaegui et al., 2016a). The aim of this work is twofold: (i) to use the high-resolution datasets from Tell Qarassa North to reconstruct the complex dynamics of the local and regional vegetation and environmental conditions around 10.7$9.9 \mathrm{ka}$ cal. BP, tracing the evolution of different plant formations at the time when morphologically domesticated cereals appeared and developed in southern Syria; and (ii) to explore the factors that regulate the evolution of plant formations over time considering that changes in the vegetation occur as a result of the complex interaction patterns between the vegetation system and others systems (e.g. climate). To address these issues we carry out, for the first time, an inter-disciplinary study combining pollen, opal phytoliths, wood charcoal remains and stable carbon isotope signature of wood charcoals from 
archaeological contexts. This work constitutes a substantial contribution to the understanding of environmental conditions at the time of cereal domestication in southern Syria and the climatic and anthropogenic factors that shaped past vegetation prior and during the development of agriculture in southwest Asia.

\section{Tell Qarassa North and its current environmental context}

The site of Tell Qarassa North was excavated in 2009 and 2010 by a Spanish team (Ibáñez et al., 2009, 2010a, 2010b) as part of the Syrian-French-Spanish archaeological research project around the palaeo-lake of Qarassa (Braemer et al., 2007, 2011). The site is located $25 \mathrm{~km}$ to the west of the Jabal al-Arab mountain range (36 $49^{\circ} 54^{\prime \prime}$ 'N-41 $27^{\prime} 40^{\prime}$ ' E, $750 \mathrm{~m}$ a.s.1.) and $20 \mathrm{~km}$ from the city of Sweida, south Syria (Figure 1a). The early PPNB levels of Tell Qarassa North comprise square shaped wood-made and stone-made architecture (Ibañez et al., 2009; Balbo et al., 2012), ground stone tools such as saddle querns and mortars, imported materials such as obsidian (Ibañez et al., 2009), diverse funerary customs (Santana et al., 2012, 2015), anthropogenic figurines (Ibañez et al., 2014), as well as faunal remains including primarily goat (L. Gourichon in Ibañez et al., 2010a). Tell Qarassa North is one of the two sites in the southern-central Levant (along with Tell Aswad, Tanno and Willcox, 2012) that has provided evidence for the presence of morphologically domesticated-type cereals (Arranz-Otaegui et al., 2016a).

Present-day climate in the Jabal al-Arab comprise cold winters (average temperature of $-2{ }^{\circ} \mathrm{C}$, and snow accumulations in some areas) and hot summers (mean temperatures of around $29 \mathrm{C}^{\mathbf{o}}$ ). The area where Tell Qarassa North is located receives a mean annual precipitation of around $350 \mathrm{~mm}$ (Chikhali and Amri, 2000; Traboulsi, 2013), and it is characterized by a large basaltic field with many locally interconnected multilayer aquifers that act as water conduits at different depths, allowing the formation of numerous springs, water ponds and lakes (Braemer et al., 2009; E. Iriarte and A. Balbo in Ibáñez et al., 2010a). Tell Qarassa is located in the southern border of a Pleistocene lava field, which is characterised by very scarce soil cover (Figure 1b). To the south of the tell Pliocene basaltic materials are found, which provide rich soils to carry out agricultural activities. To the east of the site, there is evidence of an ancient lake (dated broadly from the late Pleistocene to the mid-Holocene) and towards the south a temporary river is found (Braemer et al., 2009; E. Iriarte and A. Balbo in Ibañez et al., 2009, 2010a). 
Figure 1. A) Location of Tell Qarassa North in southwest Asia and B) detail of the surrounding area, including the paleolake (in blue) and the Leja Basaltic plain to the north (in yellow). B) Stratigraphy profiles of excavation areas XYZ and VU at Tell Qarassa North showing site phases and chronology. (For interpretation of the references to colour in this figure legend, the reader is referred to the web version of this article)
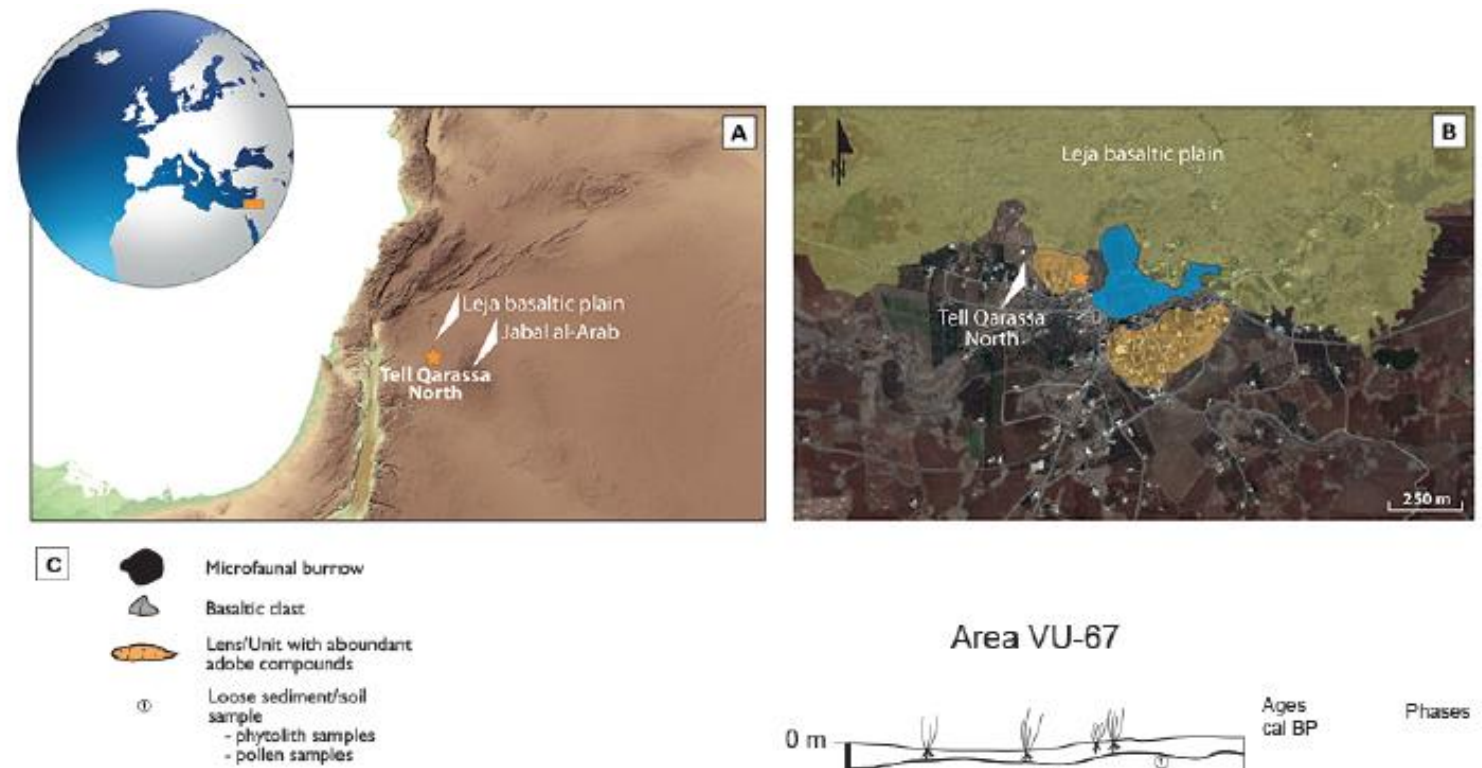

\section{Area VU-67}

Area XYZ-67/68/69
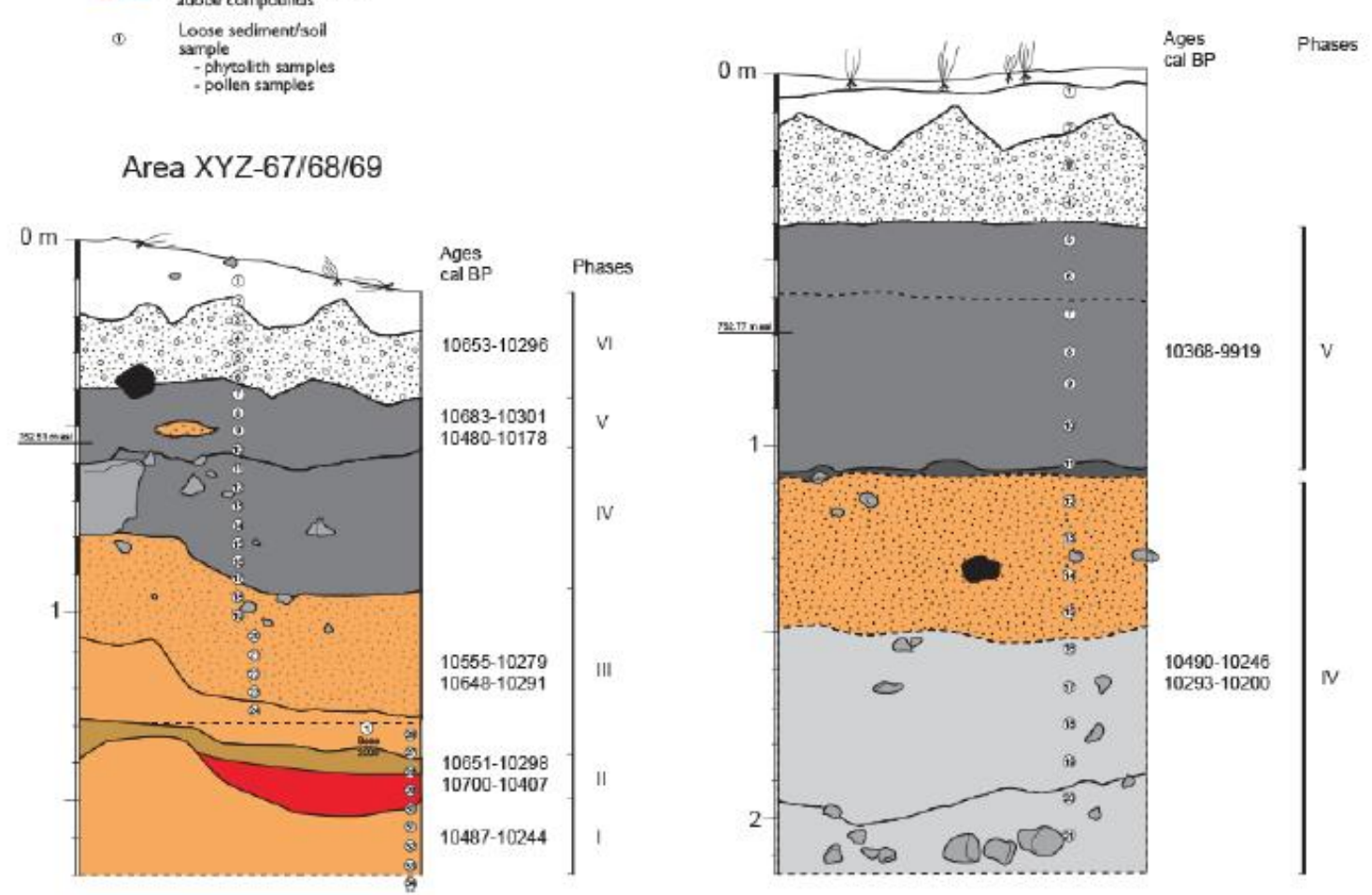

The Jabal al-Arab is considered a Mediterranean island within the Irano-Turanian region (Chikhali and Amri, 2000). The current vegetation in the area is rich and diverse with at least 900 species and various endemic taxa. Three main plant communities characterize the study area (Mouterde, 1953): a) to the north (Leja area), a degraded woodland-steppe community of Pistacia atlantica (Persian turpentine tree) and Amygdalus 
korschinskii (wild almond) is dominant; b) in the central area of the Jabal al-Arab, with altitudes reaching 1000-1500 m a.s.l., an open-woodland community of Quercus calliprinos (Palestine oak) and Crataegus azarolus (hawthorn) grows, along with Pyrus syriaca (Syrian pear), Pistacia atlantica, Acer microphyllum (small leaf maple) and Crataegus sinaica (Sinai hawthorn), the latter indicating the influence of altitude and dryness; in addition, Quercus ithaburensis (Mount Thabor's oak) has also been attested in this area (Willcox, 1999); and, c) to the east of the uplands, at an altitude around $700 \mathrm{~m}$ a.s.l., with a mean annual rainfall of $80-100 \mathrm{~mm}$, dry-steppe vegetation dominated by Artemisia (wormwood) and some Chenopodiaceae (goosefoot) extends.

\section{Materials and Methods}

The plant macro-remains and micro-remains analysed in this work come from Tell Qarassa North, Zone 1, which comprises two excavation areas: XYZ-67/68/69 (hereafter referred to as area XYZ) and VU-67 (hereafter referred to as area VU) (Figure 1c) (see Balbo et al., 2012; Santana et al., 2015 for micromorphological description of the stratigraphic units). In Table S1 the available C14 dates from Tell Qarassa North are summarised. Area XYZ is dated to 10.7-10.2 ka cal. BP, which is consistent with the EPPNB period in the Levant (Kuijt and Goring-Morris, 2002). In this area, a squareshaped stone structure (space A) and an open patio area (space B) were found. The stratigraphy consists of six phases (Figure 1c; see detailed description in Santana et al., 2015). Phase I corresponds to an occupation phase characterised by beaten earth floors within the stone structures. In phase II a fire event was documented, which enabled the in situ preservation of a collapsed roof structure in space A (Balbo et al., 2012). After this fire event, a new phase of occupation was identified which included the construction of a new beaten earth floor (phase III). Area XYZ was abandoned after phase III, leading to the accumulation of a first layer of architectural and colluvial debris (phase IV). A second layer of debris dated to 10.7-10.3 ka cal. BP, including large blocks from the sidewalls, was deposited inside the perimeter both in space A and B (unit 21, phase V). During this time (around 10.5-10.2 ka cal. BP), the abandoned structures were re-used as a funerary area (Santana et al., 2015). Phase VI in area XYZ corresponds to surface layers slightly affected by agricultural activities.

In the VU area, two main occupation phases were attested. A lower phase dated to 10.5$10.2 \mathrm{ka}$ cal. BP, which was characterised by a thin layer of wood charcoal remains, similar to that attested in phase IV of the XYZ area; and an upper phase where a stone-made wall 
was found associated to human remains. The upper phase was dated to 10.4-9.9 ka cal. BP and it is, probably, contemporary to the funerary phase V in area XYZ (see Santana et al., 2015).

\subsection{Pollen analysis}

Thirty-four pollen samples were taken from the south-facing profile of square E2 in area XYZ (space A) and twenty-one from the south-facing profile of the excavation area VU. The profiles were sampled from bottom to top at $10 \mathrm{~cm}$ intervals, avoiding the mixture of macroscopic visible layers or structures (Figure 1c). The sedimentary accumulation is interpreted as a sequence of aggradational soils (or surfaces) with very low edaphization imprint. The origin of the sediment is interpreted as aeolian and also derived from the reworking of nearby building materials (see detailed descriptions in Santana et al., 2015). Samples from the top of each profile correspond to levels affected by current agricultural activities (samples 1 to 6 from phase VI in area XYZ; samples 1 to 4 from VU, Figure 1c) and they were not included in the analyses. An average of $10 \mathrm{~g}$ of sediment was chemically treated to remove the mineral fractions. The method followed for pollen and non-pollen palynomorphs (NPPs) extraction is that described by Burjachs et al. (2003), where palynomorphs were concentrated using Thoulet liquor (Goeury and de Beaulieu, 1979). The final residue was suspended in glycerine and counted until a pollen sum of 250 grains was reached, excluding NPPs and anthropogenic taxa such Cichorioideae and Cardueae (Bottema, 1975; López-Sáez et al., 2003). Slides were examined with a light microscope using a magnification of $400 \times$ or $1000 \times$. Pollen types were identified with pollen keys (Moore et al., 1991), pollen atlases (Reille, 1999), and the reference collection of the Archaeobotany Laboratory (CSIC, Madrid, Spain). Cerealia type was defined as Poaceae exceeding $45 \mu \mathrm{m}$ with a minimum annulus diameter of $8-10$ $\mu \mathrm{m}$ (Beug, 2004; López-Sáez and López-Merino, 2005). The majority of NPPs present on the pollen slides were identified and their nomenclature conforms to van Geel (2001). Pollen diagrams were drawn using TGView (Grimm, 2004). To establish the zonation of the pollen sequences, we tested several divisive and agglomerative methods with the program IBM SPSS Statistics 21. Based on the ecological meaning of the obtained zones, five and two local pollen assemblage zones (LPAZs) were constructed respectively for area XYZ and VU on the basis of agglomerative constrained cluster analysis of incremental sum of squares (Coniss) with square root transformed percentage data 
316 (Grimm, 1987). The number of statistically significant zones was determined using the broken-stick model (Bennett, 1996).

\subsection{Wood charcoal analysis}

320

The wood charcoal remains analysed in this study were collected from 64 sediment samples processed with machine-assisted flotation (59 from spaces A and B in area XYZ, and five from area VU) (see Arranz-Otaegui, 2016 and Arranz-Otaegui et al., 2016a for details about the sampling and sample processing). The remains corresponded to dispersed wood charcoal fragments found in contexts such as infill of structures, open areas, processing areas, pits, refuse and burial contexts. Wood charcoal was identified using descriptions from several atlases (Fahn et al., 1986; Neumann et al., 2001; Schweingruber, 1990; Vernet, 2001) and the modern wood reference collections housed at the Palaeobotany Laboratory Lydia Zapata (University of the Basque Country, UPV-EHU, Vitoria-Gasteiz), Institute of Archaeology (University College London) and Department of Archaeology, Classics and Egyptology (University of Liverpool). Identifications were carried out with the aid of an incident light microscope (Olympus BX50) with different magnifications $(10 \times$ to $50 \times)$. The majority of the wood fragments analysed at Tell Qarassa North was sized between 2-4 mm. In accordance with Chabal $(1989,1991)$, rare taxa were always smaller than $4 \mathrm{~mm}$, whilst the most common taxa were found both within 2-4 $\mathrm{mm}$ and $>4 \mathrm{~mm}$ size ranges. Saturation curves were used to establish the minimum number of charcoal fragments to be analysed per sample. These curves are exponential, the higher the number of species represented in a given sample, the higher the number of charcoal fragments that need to be analysed to grant their statistical representativeness. At Tell Qarassa North, saturation curves were used in all samples containing more than 100 wood charcoal fragments and indicated that the identification of 100 wood charcoal fragments was sufficient to ensure taxa representation.

\subsection{Stable carbon isotope analysis}

Stable carbon isotope analysis was carried out in wood charcoal remains of Pistacia sp. (pistachio) and Amygdalus sp. (almond) to characterize the water availability conditions of this site (Araus et al., 2014; Fiorentino et al., 2015). The assemblage includes dispersed wood charcoal remains from different contexts processed with flotation (as described above), as well as charcoal remains from a primary deposit, a burnt roof structure, recovered in situ (Balbo et al., 2012). The growth-ring curvature of the wood charcoal 
fragments was evaluated following Marguerie and Hunot (2007). This method provides information to characterise what part of the tree was used (e.g. trunks or branches) and assess whether biases exist in the isotopic content of biologically old (i.e. trunk) or young (i.e. branch) specimens.

Carbonate crusts in charcoals were removed by soaking each charcoal sample separately in $6 \mathrm{M} \mathrm{HCl}$ for $24 \mathrm{~h}$ at room temperature and then rinsing the grain repeatedly with distilled water (DeNiro and Hastorf, 1985; Ferrio et al., 2004). All samples were oven-dried at $60^{\circ} \mathrm{C}$ for $24 \mathrm{~h}$ before milling to a fine powder for isotope analyses. The stable isotope composition of carbon $\left(\delta^{13} \mathrm{C}\right.$, referred to the VPDB standard) was determined by elemental analysis and isotope ratio mass spectrometry (EA/IRMS) at the Isotope Services of the University of Barcelona (Barcelona, Spain). The overall analytical precision was about $0.1 \%$. Carbon isotope discrimination $\left(\Delta^{13} \mathrm{C}\right)$ of archaeobotanical samples was calculated from grain $\delta^{13} \mathrm{C}$ and from the $\delta^{13} \mathrm{C}$ of atmospheric $\mathrm{CO}_{2}$, as follows:

$\Delta^{13} \mathrm{C}(\% 0)=\left(\delta^{13} \mathrm{C}_{\text {air }}-\delta^{13} \mathrm{C}_{\text {plant }}\right) /\left[1+\left(\delta^{13} \mathrm{C}_{\text {plant }} / 1000\right)\right]$

where $\delta^{13} \mathrm{C}_{\text {air }}$ and $\delta^{13} \mathrm{C}_{\text {plant }}$ denote air and plant $\delta^{13} \mathrm{C}$, respectively (Farquhar et al., 1989). The $\delta^{13} \mathrm{C}_{\text {air }}$ was inferred by interpolating a range of data from Antarctic ice-core records together with modern data from two Antarctic stations (Halley Bay and Palmer Station) of the CU-INSTAAR/NOAA-CMDL network for atmospheric $\mathrm{CO}_{2}$ (ftp://ftp.cmdl.noaa.gov/ccg/co2c13/flask/readme.html), as described elsewhere (Ferrio et al., 2005). The whole $\delta^{13} \mathrm{C}_{\text {air }}$ dataset thus obtained covered the period from 16,100 BCE to 2003 CE (data available at http://web.udl.es/usuaris/x3845331/AIRCO2_LOESS.xls). The provenance, dating as well as the $\delta^{13} \mathrm{C}$ and $\Delta^{13} \mathrm{C}$ of each sample used in this study and the corresponding $\delta^{13} \mathrm{C}_{\text {air }}$ are detailed in the Supplemental Information Table S2.

\subsection{Phytolith analysis}

Seven samples from area XYZ (square E2, south-facing profile) and eleven from area VU (south profile) were selected for phytolith analysis. Samples were obtained from different contexts described in the field as filling deposits, open spaces and funerary areas. The methods used are similar to those developed by Katz et al. (2010). A weighed aliquot of between 30-40 mg of dried sediment was treated with $50 \mu \mathrm{l}$ of a volume solution of $6 \mathrm{~N}$ $\mathrm{HCl}$. The mineral components of the samples were then separated according to their 
400

401

402

403

404

405

406

407

408

densities in order to concentrate the phytoliths using $450 \mu 12.4 \mathrm{~g} / \mathrm{ml}$ sodium polytungstate solution $\left[\mathrm{Na}_{6}\left(\mathrm{H}_{2} \mathrm{~W}_{12} \mathrm{O}_{40}\right)\right]$. Microscope slides were mounted with $50 \mu \mathrm{l}$ of material. A minimum of 200 phytoliths with recognizable morphologies was examined at $200 \times$ and 400x using an Olympus BX41 optical microscope at the Department of Prehistory, Ancient History and Archaeology from the University of Barcelona. The estimated phytolith numbers per gram of sediment are related to the initial sample weight and allow quantitative comparisons between the samples and excavation areas. Phytoliths that were unidentifiable because of dissolution are listed as weathered morphotypes. Multicellular structures (multi-celled or interconnected phytoliths) were also recorded. These latter data may provide information regarding the extent of silification of plant cells, as well as of preservation conditions (Albert and Weiner, 2001; Albert et al., 2008, 2011; Portillo et al., 2014, 2016). Morphological identification was based on modern plant reference collections from the Mediterranean region (Albert and Weiner, 2001; Albert et al., 2008, 2011; Portillo et al., 2014; Tsartsidou et al., 2007) and standard literature (Brown, 1984; Mulholland and Rapp, 1992; Piperno, 1988, 2006; Rosen, 1992; Twiss, 1992; Twiss et al., 1969). The terms used follow the International Code for Phytolith Nomenclature (Madella et al., 2005).

\section{Results}

\subsection{Pollen analysis}

An overall good state of preservation of pollen grains and NPPs was found at Tell Qarassa North. A total of 38 pollen and non-pollen palynomorph types were identified. Total pollen and NPP percentages from area XYZ and VU are given in Figures 2 and 3. The percentage pollen diagrams can be divided into five LPAZ zones in area XYZ and two in area VU, which correspond to phases I-V in area XYZ (LPAZs XYZ-I to XYZ-V) and the lower and upper phases in area VU (LPAZs VU-Lower and VU-Upper).

In area XYZ the oldest phases I to IV show overall high values for Quercus calliprinos (7-15\%) and Q. ithaburensis (15-25\%), along with anthropogenic herbs such as Cardueae (5-10\%), Cichorioideae (10-20\%) and Poaceae (8-13\%) (Figure 2). Anthropozoogenous taxa such as Plantago lanceolata (2-6\%), Rumex acetosa $(\sim 2 \%)$, R. acetosella $(\sim 2 \%)$ and Chenopodiaceae (3-7\%) are mainly attested in phase III, associated with maximum values of coprophilous fungi (Sordariaceae 4-6\%; Chaetomium 4\%). Increasing proportions of Cerealia are attested from phase I (around 2.2-5.4\%) to phase III (around 3.7-6.5\%). Most herbs show continuous presence during phases I to IV, but during destruction phases II and 
417 IV, anthropogenic and zoogenous taxa (Cardueae, Cichorioideae, Chenopodiaceae, Rumex

418

419

420

421

422

423

424

425

426

427

428

429

430

431

432

433

434

435

436

437

438

439

440

441 acetosa) sharply decrease, and Cerealia, Plantago lanceolata and Rumex acetosella disappear. In addition, the highest concentration of Glomus is recorded during these two destruction phases, whilst Sordariaceae disappear. The only difference between the two destruction phases (II and IV) is the high percentages of Chaetomium (6-12\%) in the latter. Apart from these, phases I-IV are overall characterized by noticeable percentages of Juniperus (1-3\%), Pistacia (4-7\%), Periploca (2-4\%), Phillyrea (1-2\%), Prunus (2-4\%), Olea (1-2\%), Rhamnus (2-4\%), Sarcopoterium (4-6\%) and Zizyphus (3-5\%) among the shrubs (note that Pistacia and Amygdalus are commonly under-represented in palynological analyses, e.g. Rossignol-Strick, 1993; Roberts, 2002). Wet meadow steppe taxa (Cyperaceae) show very low values $(<2 \%)$, whilst Artemisia shows its highest percentages during phase IV (6-10\%). Values for the rest of taxa, such as Acer (1-2\%) and Pinus nigra (3-5\%) remain stable during phases I-IV, whilst Betula, Cedrus, Corylus, Tamarix, Fraxinus, Populus and Salix types are rare $(<2 \%)$ and sporadic.

Figure 2. Pollen and NPP diagram from Tell Qarassa North XYZ.

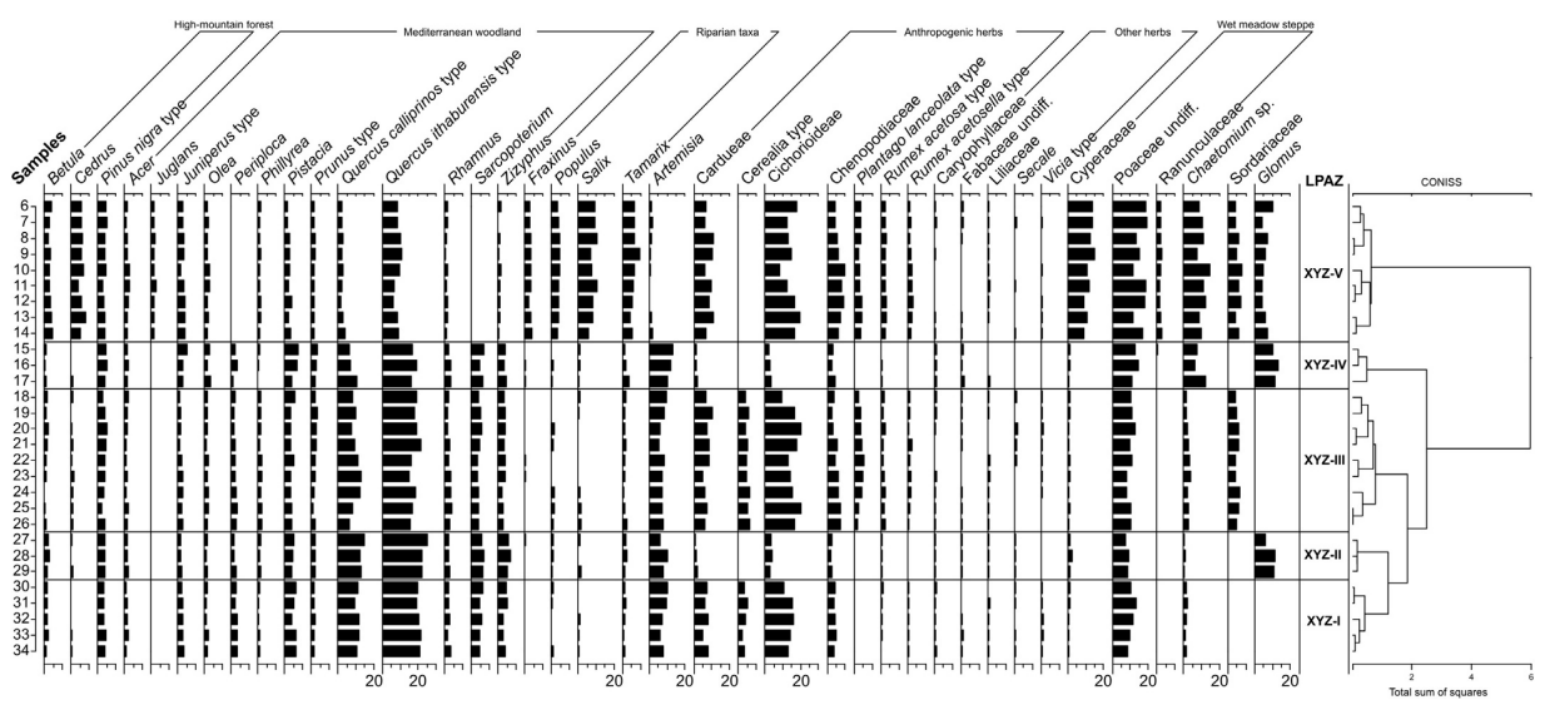

During phase V (LPAZ XYZ-5), which corresponds to the abandonment and later reuse of the area for funerary purposes, important changes occur in terms of vegetation composition (Figure 2). On the one hand, taxa such as Olea, Pistacia (2-4\%), Quercus calliprinos (2-4\%), Q. ithaburensis (6-11\%), Rhamnus and Zizyphus steadily decline and Periploca and Sarcopoterium disappear. On the other hand, Betula (maximum 4\%), Cedrus (7\%), Fraxinus (4\%), Populus (5\%), Salix (10\%) and Tamarix (10\%) notably 
442

443

444

445

446

447

448

449

450

451

452

453

454

455

456

457

458

459

460

461

462

463

464

465

increase, as well as Juglans, which is recorded for the first time. Anthropogenic (Cardueae, Cichorioideae) and anthropozoogenic (Chenopodiaceae, Plantago lanceolata, Rumex acetosa, R. acetosella) herbs increase slightly, although Cerealia are absent. Sordariaceae are documented again (4-6\%), whereas Chaetomium and Glomus maintain a continuous presence. Also, wet meadow steppe taxa (Cyperaceae 13-15\%; Ranunculaceae 2-3\%) show highest values during this time, whilst Artemisia drops sharply $(<2 \%)$.

Figure 3. Pollen and NPP diagram from Tell Qarassa North VU.

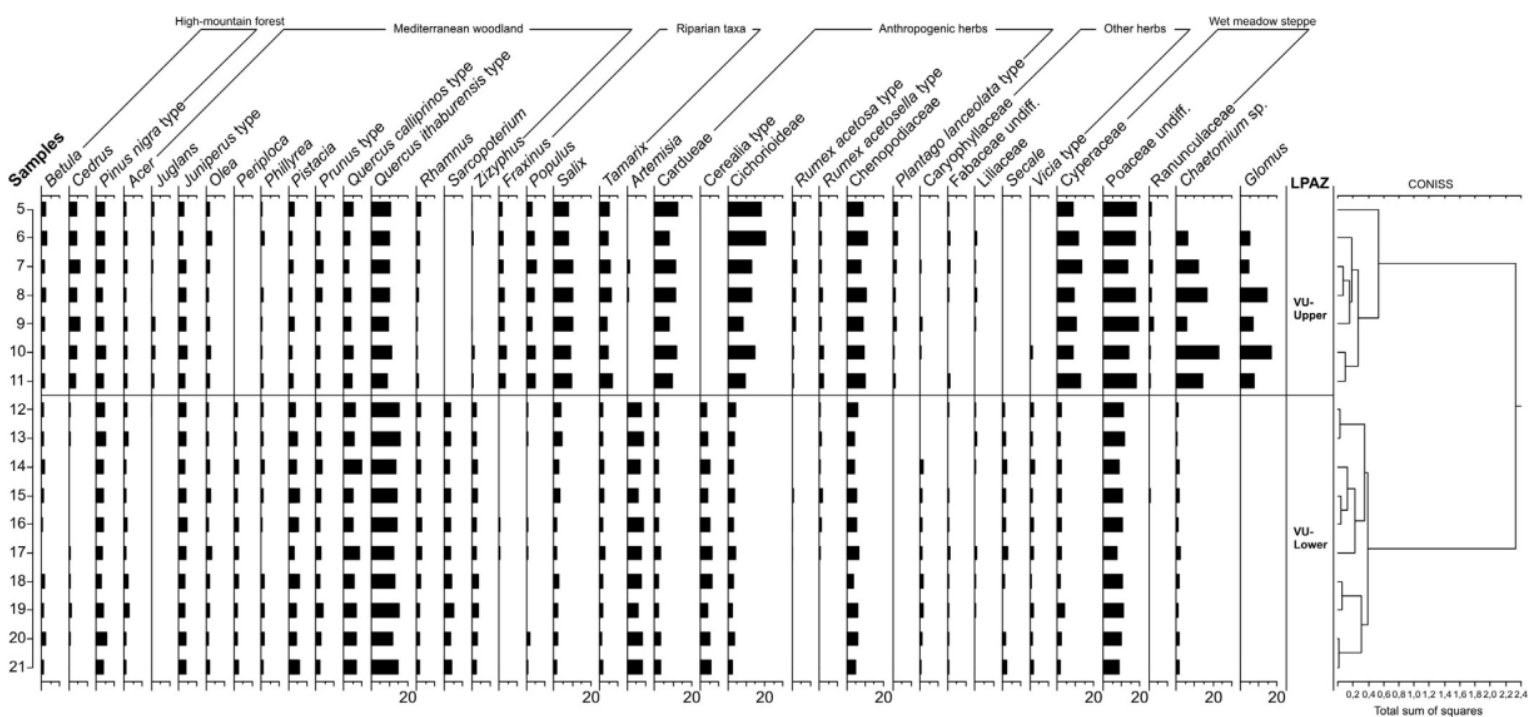

In area VU (Figure 3), results for the lower phase (LPAZ VU-Lower) indicate relatively high percentages of arboreal pollen mainly comprising Quercus ithaburensis (12-16\%), Q. calliprinos (5-10\%) and Pistacia (10-14\%), and to lesser extent Acer, Betula, Salix (<4\%) and Pinus nigra (3-6\%). Other trees such as Tamarix, Populus and Fraxinus as well as Cedrus are present, but show low percentages $(<2 \%)$. Shrubs are abundant, with Prunus $(\sim 3 \%)$, Olea ( 2\%), Periploca ( 2\%), Phillyrea (1-2\%), Rhamnus (2-3\%), Sarcopoterium (3-5\%) and Zizyphus (3-4\%) being the most important taxa. Poaceae (5-12\%) are the main herbaceous component. Anthropogenic taxa (Cardueae, Cichorioideae), and anthropozoogenic nitrophilous herbs (Rumex acetosella) are also present although with low percentages, similar to those attested during destruction phases II and IV in area XYZ. Hygrophytic taxa (Cyperaceae, Ranunculaceae) are represented by low percentages ( 2\%), while dry steppe taxa such as Artemisia show high values (6-11\%), very similar to the evidence attested in phase IV in area XYZ. However, the lower phase of VU show high 
values of Cerealia (3.3-6.6\%), which are similar to those identified during occupation phase III in area XYZ.

During the upper phase of area VU (Figure 3, LPAZ VU-Upper), the results indicate a synchronous decrease of Pistacia (4-8\%), Quercus calliprinos (3-5\%) and Q. ithaburensis (9-11\%), comparable to the decrease observed during phase V in area XYZ. Acer, Pinus nigra and Juniperus maintain similar percentages as those attested during the previous period. Betula, Cedrus (4-6\%), Fraxinus, Populus, Salix (8-11\%) and Tamarix (4-7\%) increase significantly, and Juglans (1-2\%) appears for the first time. Most of the shrubs (Prunus, Olea, Phillyrea) maintain a continuous and significant presence throughout the zone, although other shrub taxa percentages (Rhamnus, Zizyphus) display a decreasing trend, and Sarcopoterium and Periploca disappear. In comparison to the previous phase, anthropogenic and anthropozoogenic taxa such as Cardueae (8-12\%), Cichorioideae (921\%), Rumex acetosa, $R$. acetosella and Plantago lanceolata ( 2\%) show an increasing trend, as well as Chenopodiaceae (8-11\%), while Cerealia disappear. This is also observed in phase V from area XYZ. Artemisia decreases $(<1 \%)$ whereas Poaceae $(13-19 \%)$, Ranunculaceae and Cyperaceae (9-13\%) significantly increase their values. NPPs indicative of erosion and fire events, as well as pastoral activities (Chaetomium, Glomus) are at their maximum values in this pollen sequence (23 and $17 \%$, respectively), following synchronous trends.

\subsection{Wood charcoal analysis}

A total of 5274 wood charcoal fragments were analysed and 14 taxa were identified in areas XYZ and VU (see the main taxa found in Figure 4). It must be noted that there were no significant differences in terms of species representation by phase (i.e. XYZ-I-V) and by type of context (i.e. infill of structure, open areas etc.). Thus, in Table 1 a summary of the ubiquity and absolute counts for area XYZ and VU is given. The results show that Pistacia and Amygdalus were the most common taxa in all analysed samples, both in terms of ubiquity (between 96.9-98.4\% of samples) and absolute counts (between c. 30-50\%) (Note that these two taxa might be over-represented in the wood charcoal assemblage, Arranz-Otaegui, 2016). In general, the percentages of Anacardiaceae (including Pistacia) slightly decreased from $58.7 \%$ in area XYZ to $54.4 \%$ in area VU, whereas Rosaceae maintained similar proportions (from 34.2 to $35.5 \%$ ). The rest of taxa were rare both in terms of ubiquity ( $<35 \%$ of samples) and absolute counts (percentage counts $<1 \%$ ). Salicaceae (comprising cf. Salix, Salix, and cf. Populus) was only present in area XYZ 
500 (phases I-IV), along with Tamarix, Cedrus libani and Fraxinus, which were also present 501 but in slightly lower proportions (percentage counts <1\%). Quercus was only identified in 502 area VU (upper phase) and comprised 1.8\% of the assemblage. At least one fragment 503 corresponded to evergreen-type Quercus (Fig. 4F), although the presence of deciduous 504 Quercus cannot be excluded. Other taxa were rare and only found in specific contexts of 505 the excavation area XYZ, such as Acer in a pit sample, Chenopodiaceae in the infill of 506 structure and cf. Rhamnus associated to a burial.

507

\subsection{Isotope analysis on wood charcoal}

509 Carbon isotope discrimination $\left(\Delta^{13} \mathrm{C}\right)$ values for a total of 74 Pistacia and 28 510 Amygdalus wood charcoal samples were analysed (Table S2). Curvature was positively 511 assessed in 57 wood charcoal fragments corresponding to scattered remains and 29 512 samples from the rood structure (Table S2). The results showed the predominance of low 513 curvature fragments $(80.7 \%$ and $65.5 \%$ respectively), followed by medium curvature 514 (12.3\% and $10.3 \%$ respectively) and strong curvature (7\% and $10.3 \%$ respectively). There 515 were no significant differences in terms of $\Delta 13 \mathrm{C}$ between biologically older (e.g. weak 516 curvature) and younger (moderate or strong curvature) specimens from the same phase 517 (Table S3). In fact, in some cases wood charcoal fragments with strong curvature tended to 518 exhibit lower (phase IV) or higher (phase V) values than the fragments with weak 519 curvature. Considering this we cannot conclude that in our study the age of the wood 520 sampled may bias the $\Delta 13 \mathrm{C}$ of the samples analysed. Mean values were plotted for the six 521 phases studied in the XYZ area and the upper and lower phases of the VU area (Fig. 5). In 522 the case of Amygdalus, values were near 19\%o through all the period studied, whereas for 523 Pistacia values were in general slightly lower (but above 18\%o). Both species tended to 524 show lower values in phase IV compared with the other five phases. The mean $\Delta 13 \mathrm{C}$ 525 values of the samples of the two species recovered from the roof and corresponding to 526 phase II in XYZ area were clearly lower (nearly 18\%o for Pistacia and slightly above 17\%o 527 for Amygdalus). 
Table 1. Results of the taxonomic analyses of the wood charcoal remains from excavation areas XYZ and VU at Tell Qarassa North.

\begin{tabular}{|c|c|c|c|c|c|c|c|c|c|c|c|c|c|}
\hline \multirow{2}{*}{\multicolumn{2}{|c|}{$\begin{array}{c}\text { Taxonomic analysis Scattered } \\
\text { remains }\end{array}$}} & \multicolumn{4}{|c|}{$\begin{array}{c}\text { XYZ-67/68/69 } \\
\text { (number of samples: 59) }\end{array}$} & \multicolumn{4}{|c|}{$\begin{array}{c}\text { VU-67 } \\
\text { (number of samples: 5) }\end{array}$} & \multicolumn{4}{|c|}{ Total fragments by taxa } \\
\hline & & counts & $\begin{array}{l}\% \text { frag. } \\
\text { counts }\end{array}$ & presence & $\begin{array}{c}\text { ubiquity } \\
(\%)\end{array}$ & counts & $\begin{array}{l}\% \text { frag. } \\
\text { counts }\end{array}$ & presence & $\begin{array}{c}\text { ubiquity } \\
(\%)\end{array}$ & counts & $\begin{array}{l}\text { \% frag. } \\
\text { counts }\end{array}$ & presence & $\begin{array}{c}\text { ubiquity } \\
(\%)\end{array}$ \\
\hline \multirow{4}{*}{$\begin{array}{l}\text { woodland- } \\
\text { steppe }\end{array}$} & Pistacia sp. & 2556 & 56.3 & 57 & 96.6 & 238 & 52.8 & 5 & 100.0 & 2794 & 56.4 & 62 & 96.9 \\
\hline & Anacardiaceae & 108 & 2.4 & 33 & 55.9 & 7 & 1.6 & 3 & 60.0 & 115 & 2.3 & 36 & 56.3 \\
\hline & Amygdalus sp. & 1376 & 30.3 & 58 & 98.3 & 147 & 32.6 & 5 & 100.0 & 1523 & 30.8 & 63 & 98.4 \\
\hline & Rosaceae & 179 & 3.9 & 41 & 69.5 & 13 & 2.9 & 4 & 80.0 & 192 & 3.9 & 45 & 70.3 \\
\hline \multirow{2}{*}{ oak-woodland } & Acer sp. & 4 & 0.1 & 1 & 1.7 & 0 & 0.0 & 0 & 0.0 & 4 & 0.1 & 1 & 1.6 \\
\hline & Quercus sp. & 0 & 0.0 & 0 & 0.0 & 8 & 1.8 & 2 & 40.0 & 8 & 0.2 & 2 & 3.1 \\
\hline coniferous for. & Cedrus libani & 37 & 0.8 & 14 & 23.7 & 0 & 0.0 & 0 & 0.0 & 37 & 0.7 & 14 & 21.9 \\
\hline \multirow{4}{*}{$\begin{array}{l}\text { wetland and } \\
\text { salt marsh }\end{array}$} & Salicaceae & 192 & 4.2 & 26 & 44.1 & 0 & 0.0 & 0 & 0.0 & 192 & 3.9 & 11 & 17.2 \\
\hline & Fraxinus sp. & 27 & 0.5 & 12 & 20.3 & 0 & 0.0 & 0 & 0.0 & 24 & 0.5 & 12 & 18.8 \\
\hline & Tamarix sp. & 43 & 0.9 & 20 & 33.9 & 1 & 0.2 & 1 & 20.0 & 44 & 0.9 & 21 & 32.8 \\
\hline & Tamaricaceae & 13 & 0.3 & 8 & 13.6 & 0 & 0.0 & 0 & 0.0 & 13 & 0.3 & 8 & 12.5 \\
\hline \multirow[t]{3}{*}{ steppe } & Chenopodiaceae & 2 & 0.0 & 2 & 3.4 & 0 & 0.0 & 0 & 0.0 & 2 & 0.0 & 1 & 1.6 \\
\hline & cf. Rhamnus & 1 & 0.0 & 1 & 1.7 & 0 & 0.0 & 0 & 0.0 & 1 & 0.0 & 1 & 1.6 \\
\hline & cf. Fabaceae & 1 & 0.0 & 1 & 1.7 & 0 & 0.0 & 0 & 0.0 & 1 & 0.0 & 1 & 1.6 \\
\hline \multicolumn{2}{|l|}{ Indeterminate } & 283 & & 49 & 83.1 & 37 & 8.2 & 4 & 80.0 & 320 & & 53 & 82.8 \\
\hline \multicolumn{2}{|l|}{ other (pith, bark) } & 1 & & 1 & 1.7 & 0 & 0.0 & 0 & 0.0 & 1 & & 1 & 1.6 \\
\hline \multicolumn{2}{|l|}{ Total } & 4823 & 100.0 & 59 & 100.0 & 451 & 100.0 & 5 & 100.0 & 5274 & 100.0 & 64 & 100.0 \\
\hline
\end{tabular}


531 Figure 4. The wood charcoal taxa found at Tell Qarassa North: A and B) transverse and 532 longitudinal tangential sections of Pistacia sp.; C and D) transverse and longitudinal 533 tangential sections of Amygdalus sp.; E and F) transverse and longitudinal radial section of 534 Salicaceae cf. Salix; G) transverse section of Fraxinus; H) transverse section of Tamarix; I 535 and J) transverse and longitudinal tangential sections of Quercus (evergreen-type); K) 536 transverse section of Acer; L) transverse section of cf. Fabaceae; M and N) transverse and 537 radial sections (showing scalloped tori) of Cedrus libani; O) transverse section of 538 Rhamnus; P) transverse section of Chenopodiaceae. 

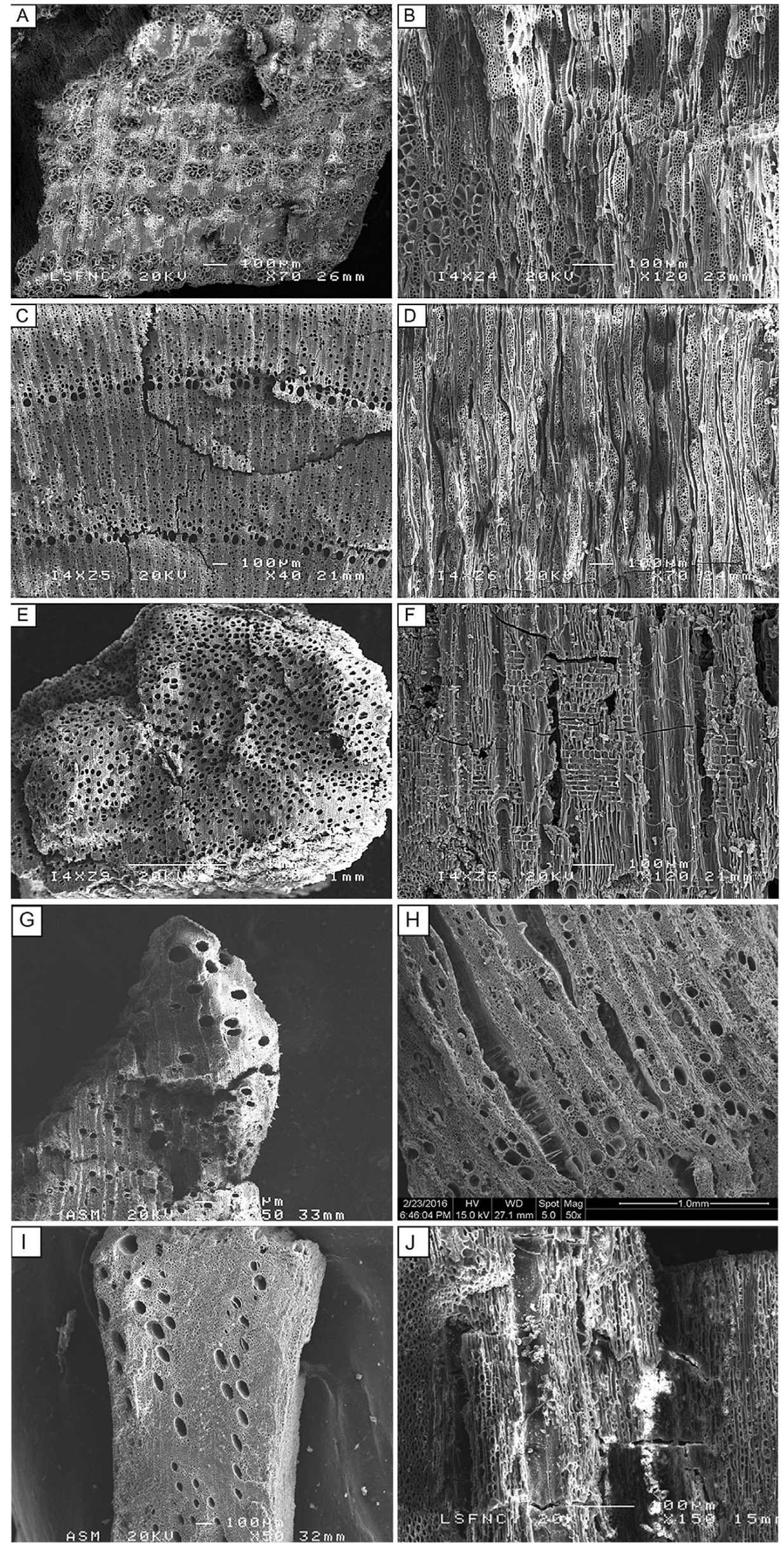

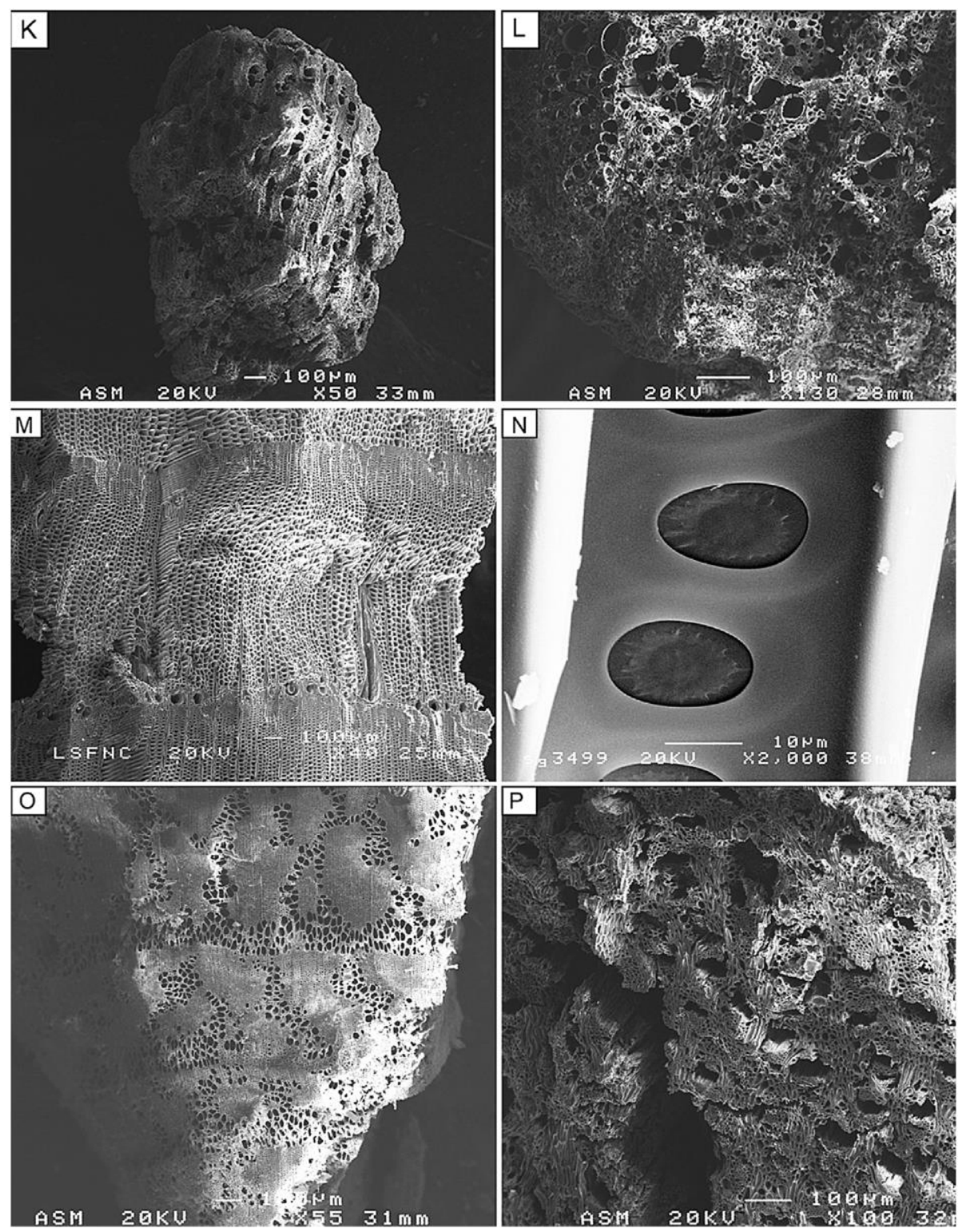

541

Fig. 4. (continued).

543

544

545

546

547

548

549

550

551 
552 Figure 5. Evolution through time of the carbon isotope discrimination $\left(\Delta^{13} \mathrm{C}\right)$ of 553 Amygdalus and Pistacia. Phases I to VI correspond to the XYZ area, whereas the lower 554 and upper phases refer to the VU area. Values plotted are means \pm SE. Details about the 555 individual samples analysed can be found in Table S2.

556

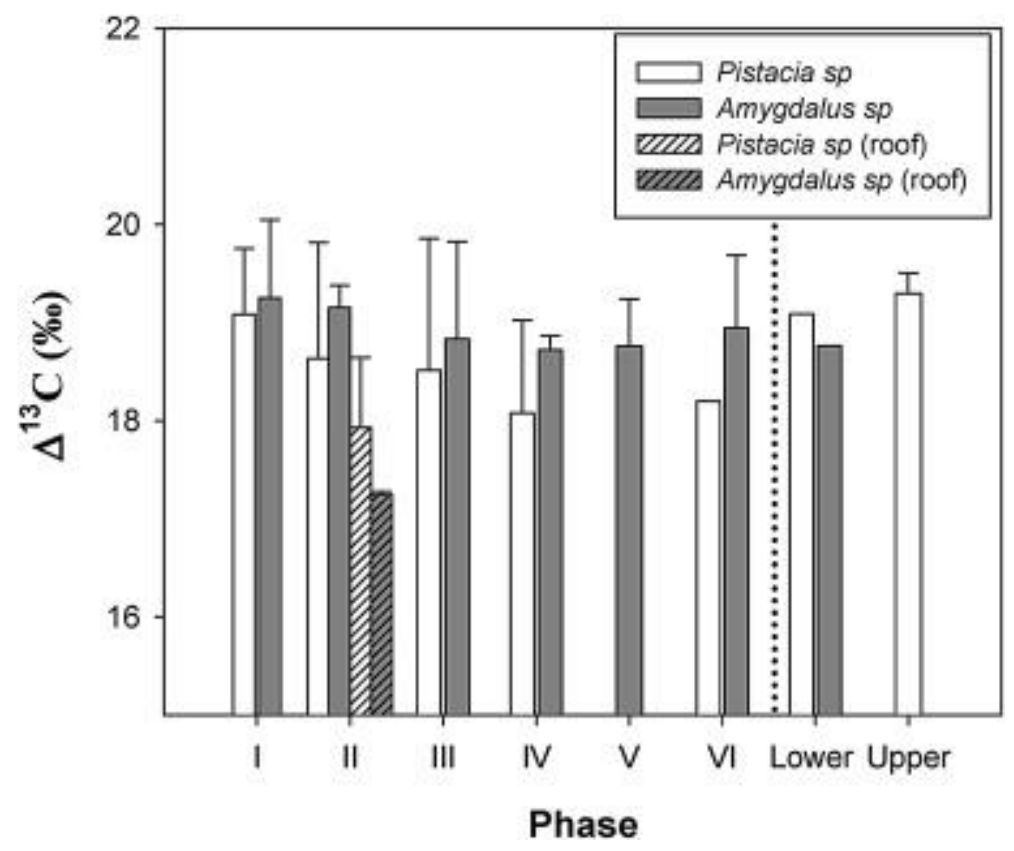

557

\subsection{Phytolith analysis}

559

Phytoliths were abundant in all the samples examined (ranging from 1 to 2.6 million phytoliths per gram of sediment in XYZ samples and 0.7 to 1.7 in area VU; Table S4). Overall, the low proportions of weathered phytoliths, together with the presence of multicellular or anatomically or connected phytoliths in most of the samples, are indicative of a good state of preservation of the assemblages. The morphological results indicated that grasses dominated the phytolith record, with around $80 \%$ or more of all the counted morphotypes (Figure 6). In addition to dicotyledonous morphotypes, diagnostic phytoliths from the Cyperaceae family (sedges), which are common in wet environments, were noted in both profiles, although to a lesser extent. Grass phytoliths were divided into the different anatomical plant parts in which they were formed (Figure 6). Epidermal cells from grass leaves and stems, including prickles, bulliform cells and stomata, were observed in all the samples in different amounts (between c. 30-65\%). The results show that multi-celled concentrations of these plant parts were high in samples related to mud building materials, such as sun-dried adobe compounds (up to $42 \%$ in sample 29, in phase II, area XYZ; Table S4 and Figure 7a). Additionally, grass phytoliths derived from their floral parts were abundantly noted in most of the samples ( $30 \%$ or more of all grass morphotypes). 
575 Inflorescences were characterized mainly by decorated dendritic and echinate long cells in 576 addition to epidermal papillae cells (Figure 7b). Grasses belonged to the Pooideae 577 subfamily which are common in well-watered woodlands and include major cereals. 578 Multi-celled phytoliths from the husks and culms of Pooids, including Triticum sp. and 579 Hordeum sp. were identified in both profiles (Figure 7c).

581 Fig. 6. Left: Relative abundances of phytoliths obtained from XYZ and VU samples; 582 Right: anatomical origin of grass phytoliths.

583

584

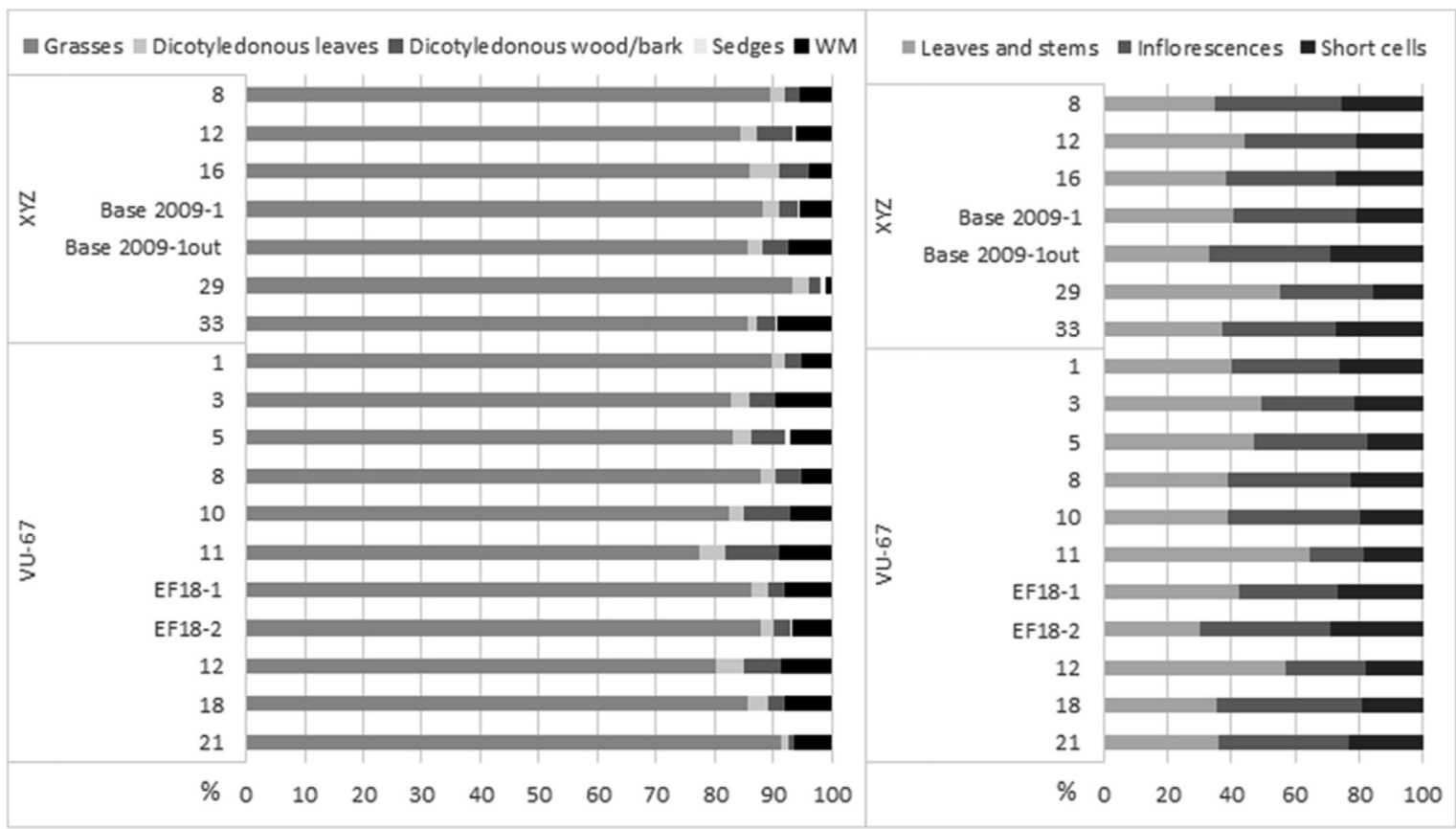

585

586 Figure 7. Photomicrographs of phytoliths identified in XYZ samples (scale 400x): A) 587 multicellular structure of long cells with stomata from grass stems (sample 29, phase II); 588 B) epidermal appendage papillae cells (sample 8, phase V); C) multicellular structure of 589 dendritic long cells with short cell rondels from Pooid husk (sample 29, phase II).

590
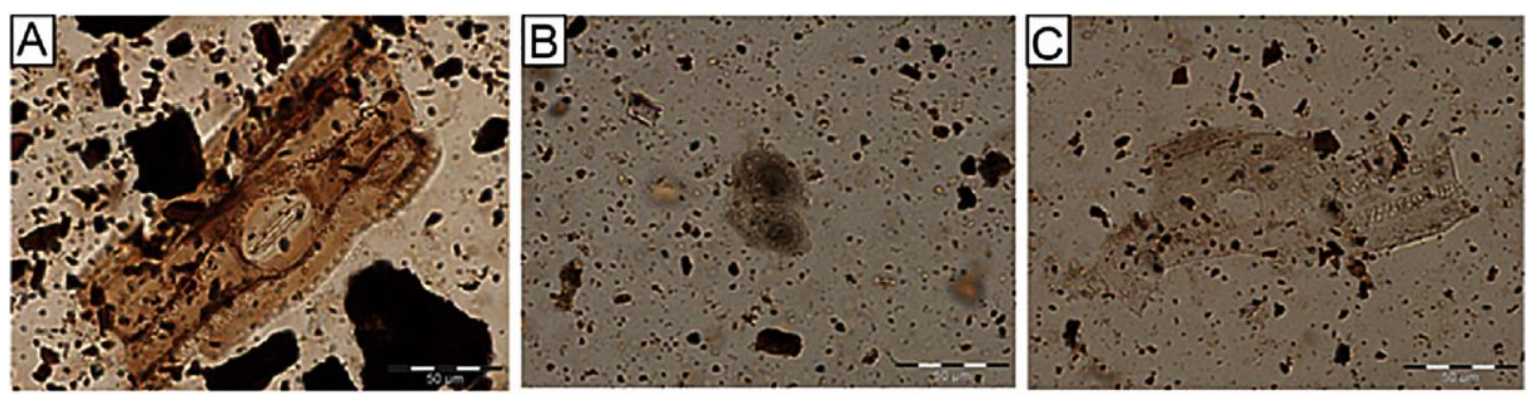


\section{Discussion}

We follow Meadow's approach of system thinking (2008) to characterise past vegetation at Tell Qarassa North and assess its evolution through time. We consider that vegetation represents a system, and it is defined as an interconnected set of elements (e.g. trees, herbs) that are coherently organised to achieve a particular purpose (e.g. to reproduce and survive through time), and that are regulated by different inflows and outflows. In the following lines we describe the elements that define the vegetation system at Tell Qarassa North (section 6.1.), as well as characterise the environmental conditions at the time of cereal domestication (section 6.2.). Following this, we explore the complex patterns of interaction between the local and regional vegetation around Tell Qarassa North and other systems (e.g. climate and human) from 10.7 to 9.9 ka cal. BP (section 6.3.).

\subsection{The elements of the vegetation system}

According to pollen, wood charcoal and phytolith evidence, from 10.7 to $9.9 \mathrm{ka}$ cal. BP, four main plant formations grew in the area around Tell Qarassa North. These comprised Pistacia and Amygdalus woodland-steppe, wetland vegetation, Mediterranean open oakwoodlands, and high-mountain coniferous forests (Figure 8).

Wood charcoal remains from archaeological sites represent the remains of local and easily collected wood resources (Smart and Hoffman, 1988). The anthracological assemblage showed that Pistacia and Amygdalus were the preferred source of fuel during the whole occupation period (10.7-9.9 ka cal. BP) (Table 1). Considering the morphological characteristics of the nutshells found at the site (Arranz-Otaegui et al., 2016a), the remains probably represent Amygdalus korshinskyi and Pistacia palaestina/atlantica. These species are nowadays leading elements of Irano-Turanian woodland-steppe formations, and grow along with an understory of Poaceae, Chenopodiaceae and other steppic plants (Zohary, 1973). In addition to these, $Q$. ithaburensis is also common in Pistacia-Amygdalus woodland and woodland-steppe formations in the Mediterranean and Irano-Turanian borderlands (Zohary, 1973). This association was attested in Bronze Age and Roman sites located in the plains and mountainous areas of Jabal al-Arab, less than $10 \mathrm{~km}$ from Tell Qarassa North (Willcox, 1999). In modern pollen rain studies conducted in the eastern Mediterranean and the Middle East values of Quercus pollen higher than 20\% indicate the local presence of oak forests or maquis, while percentages of the order of $6-8 \%$ reflect the regional nature of 
627 their origin (e.g. Bottema, 1977; Davies and Fall, 2001; Kaniewski et al., 2011 ; Fall, 628 2012). At Tell Qarassa North percentages of Quercus ithaburensis pollen were up to 25\%

629 (Fig. 2), suggesting that this species could have grown in the vicinity. However, the 630 proportions of Pistacia pollen found at the site (between 4 and 7\% in area XYZ and 4631 14\% in area VU, Fig. 2; Fig. 3) are indicative of Pistacia tree dominance over Quercus, 632 especially in Amygdalus-closed forest vegetation (Rossignol-Strick, 1995). Considering 633 the remarkable percentages of grasses and steppic plants in the pollen records ( Fig. 2 ; 634 Fig. 3) and the non-woody plant macroremains of the site (Arranz-Otaegui et al., 2016a), it 635 is likely that the immediate areas around Tell Qarassa North were characterised by vast open areas with broadly spaced Pistacia and Amygdalus trees alternating with Quercus ithaburensis, shrubby Rosaceae, Rhamnus and Acer, and extensive patches of grasses and steppe vegetation such as Capparis, Camelina, Stipa, Trigonella astroites growing within the scattered trees ( Mouterde, 1953 ; Zohary, 1973). This type of vegetation would have been primarily located to the south of the tell, where rich soils that allow agricultural activities were found (Fig. 8A), as well as to the north of the site, in the Leja area. The limited tolerance to water-saturated soils of Pistacia and Amygdalus (Zohary, 1973) would have made them less common at the eastern foot of the tell due to the existence of a lake (Ibañez et al., 2010a). The prevalence of Pistacia and Amygdalus woodland-steppe vegetation is found during the early Holocene in inland areas of southwest Asia (Fig. S1, Table S5), from southern-central Syria ( Pessin, 2004 ; Deckers et al., 2009) up to the Euphrates area (Roitel, 1997), the Anatolian Plateau ( Willcox, 1991; Asouti, 2003 ; Emery-Barbier and Thiébault, 2005), southeast Turkey (Neef, 2003) and the Zagros ( van Zeist et al., 1984 ; Riehl et al., 2015); that is, in areas that nowadays correspond to the Irano-Turanian phytogeographical region (Zohary, 1973). An open landscape comprising Pistacia forests and steppe vegetation has also been recorded in early Holocene pollen records from Anatolia ( Bottema and Woldring, 1984 ; Roberts et al., 2001), southeast Turkey ( van Zeist and Bottema, 1977; Wick et al., 2003 ; Litt et al., 2014) and Iran ( van Zeist and Bottema, 1977; Bottema, 1986 ; Djamali et al., 2008b) (Fig. S1).

Apart from Irano-Turanian elements, the wood charcoal, pollen and phytolith results reveal that riparian vegetation constituted an important component of the local vegetation at Tell Qarassa North (Table 1, Figures 2 and 3, Table S4). These included hygrophilous taxa such as Salicaceae (Populus, Salix), Fraxinus and Tamarix, along with Ficus and Vitex agnus-castus that were documented within the non-woody plant macroremains 660 (Arranz-Otaegui et al., 2016a), and annual and perennial plants of the Cyperaceae (e.g. 

overall low absolute counts in the wood charcoal assemblage of Tell Qarassa North (Table 1) it is likely they were used as importance source of fuel (Arranz-Otaegui, 2016) and building material (Balbo et al., 2012). Wetland vegetation would have been established around the shores of the ancient lake that was located at the foot of Tell Qarassa North (Figure 8B), as well as in the many water springs and the river fed by the volcanic uplands of the Jabal al-Arab (Ibañez et al., 2010b; Braemer et al., 2009). Riparian trees were commonly used as firewood and were an important element of the vegetation at contemporary sites across southwest Asia (Western, 1971; Lipshschitz and Noy, 1991; Roitel, 1997; Pessin, 2004; Austin, 2007).

The pollen records from Tell Qarassa North show the presence in the area of Quercus calliprinos along with a wide range of Mediterranean taxa such as Olea, Rhamnus, Periploca, Phillyrea, Sarcopoterium, Ziziphus and Acer (Figures 2 and 3). Q. calliprinos is the most important element of the maquis in the south-eastern part of the Mediterranean area (Zohary, 1973), and it is commonly associated with Pistacia palaestina at altitudes below $900 \mathrm{~m}$, as attested nowadays in the Hermon area (Aharnovich et al., 2014). Bobek (1963) notes that Quercus woodland and woodland-steppe formations commonly replace Pistacia-Amygdalus steppe forests in areas where annual precipitation exceed an average of $500 \mathrm{~mm}$. This pattern is observed in the Jabal al-Arab nowadays. Here, the plains (c. 700-900 $\mathrm{m}$ a.s.l) with average annual precipitation of around $250-350 \mathrm{~mm}$ are characterised by degraded woodland-steppe components, whilst Mediterranean forest vegetation composed primarily of $Q$. calliprinos are restricted to an attitude between 1000 and $1500 \mathrm{~m}$ a.s.l. and precipitation above $500 \mathrm{~mm}$ (Willcox, 1999). This would indicate that evergreen Quercus woodlands probably existed, at least, in what is known today as the "Mediterranean island" of the Jabal al-Arab (Figure 8C). However, the presence of several Mediterranean species such as Echinaria capitata, Poa bulbosa, Psilurus incurvus, Taeniatherum caput-medusae and Tolpis virgata within the non-woody plant macroremains of the site (Arranz-Otaegui et al., 2016a) and the identification of evergreen-type Quercus in the wood charcoal assemblage (Figure 4F) indicates infiltrations of Mediterranean vegetation close to the site. This is possible considering that moister condition than at present prevailed during the EPPNB in the area (see Balbo et al. 2012, see section 6.2), which would enable these plants to grow at lower altitudes than those nowadays (e.g. $1000 \mathrm{~m}$ ). The regional evidence shows that typically Mediterranean 
records from Hula (van Zeist et al., 2009), Dead Sea (Litt et al., 2012), Birkat Ram crate (Schiebel, 2013) and Ammiq wetland (Hajar et al., 2008) point out the prevalence of deciduous Quercus forests in the mountain areas of the Golan and the Beqaa (Figure S1). In the coastal areas of modern-day Israel, the wood charcoal evidence around $10.2 \mathrm{ka} \mathrm{cal}$. BP suggests the presence of Mediterranean evergreen Quercus forests (Caracuta et al., 2014) and Pistacia-Q. calliprinos associations (Liphschitz, 1997), similar to the vegetation found nowadays in the same area. In the northern part of the Dead Sea, Pistacia forests and halophytic communities (e.g. Tamarix) grew at low elevations (i.e. around $250 \mathrm{~m}$ b.s.1., Liphschitz, 2010; Western, 1971), whilst in the east, at altitudes around $700 \mathrm{~m}$ a.s.l., extensive deciduous Quercus woodlands along with some evergreen Quercus components were found (Neef, 2004). In the Jordan Valley, Pistacia trees (Asouti et al., 2015), and Juniperus woodlands (Neef, 2004; Austin, 2007) predominated along with some components of evergreen Quercus, indicating that arid areas nowadays characterised as treeless Irano-Turanian steppe and dwarf shrub were moister and more forested than at present.

Mountain vegetation is represented at Tell Qarassa North by the presence of Cedrus libani, Betula and Pinus nigra type, as noted in the wood charcoal and pollen records (Figures 2 and 3, Table 1). These taxa are likely to correspond to the 'regional' distance transport of pollen grains from the nearby highland areas (Jabal al-Arab mountain range), or even from more distant regions (e.g. Betula), as suggested in the pollen records from Hula (van Zeist et al. 2009). Mixed deciduous and coniferous forests, which grow in the oromediterranean bioclimatic zone of the Syrian and Lebanese mountains, include deciduous oaks, Pinus nigra, Juniperus excelsa and J. oxycedrus reaching up to $1900 \mathrm{~m}$ a.s.l (Zohary, 1973). At higher elevations coniferous forests mainly comprise Pinus nigra, Abies cilicica and Cedrus libani, along with various juniper species (Juniperus excelsa, J. drupacea, J. phoenicea) (Zohary, 1973). Cedrus libani is now found primarily in the mountainous areas of Lebanon, northern Syria and Turkey (Hajar et al., 2010), although it has also been observed in the Mount Hermon and the northern Golan (Neumann et al., 2007), around $60 \mathrm{~km}$ from Tell Qarassa North. Pollen records from Ammiq wetland in Lebanon (Hajar et al., 2008) suggest that coniferous forests with species such as Cedrus could have been found during the early Holocene in the Barouk Mountains (Figure S1). The presence of Cedrus wood charcoal at the PPNB site of Tell Aswad, in the Damascus Basin, was interpreted as evidence of long-distance transportation of exotic materials (Willcox, 2005). However, Cedrus libani can adapt to a wide range of soil types and 
moisture contents, including semi-arid regions with precipitation between 300 and $600 \mathrm{~mm}$ per year (Semerci, 2005), and altitudes above $900 \mathrm{~m}$ a.s.l., often between 1500-1800 m a.s.l. (Liphschitz and Biger, 1992; Hajar et al., 2010). At $25 \mathrm{~km}$ to the east of Tell Qarassa North the uplands of the Jabal al-Arab rise to $1800 \mathrm{~m}$ a.s.l., and they could have constituted a suitable area for the growth of these conifer forests during the early Holocene (Figure 8D).

Figure 8. Reconstruction of the local vegetation around Tell Qarassa North, view towards the south of the site (Author: C. Carlson). A) Woodland-steppe components such as Pistacia and Amygdalus growing close to the site; B) riparian vegetation growing along the shore of the lake and nearby water ponds; C) evergreen oak stands growing in more distant areas; D) coniferous forests growing in the mountain areas of the Jabal al-Arab (around $25 \mathrm{~km}$ from the site).

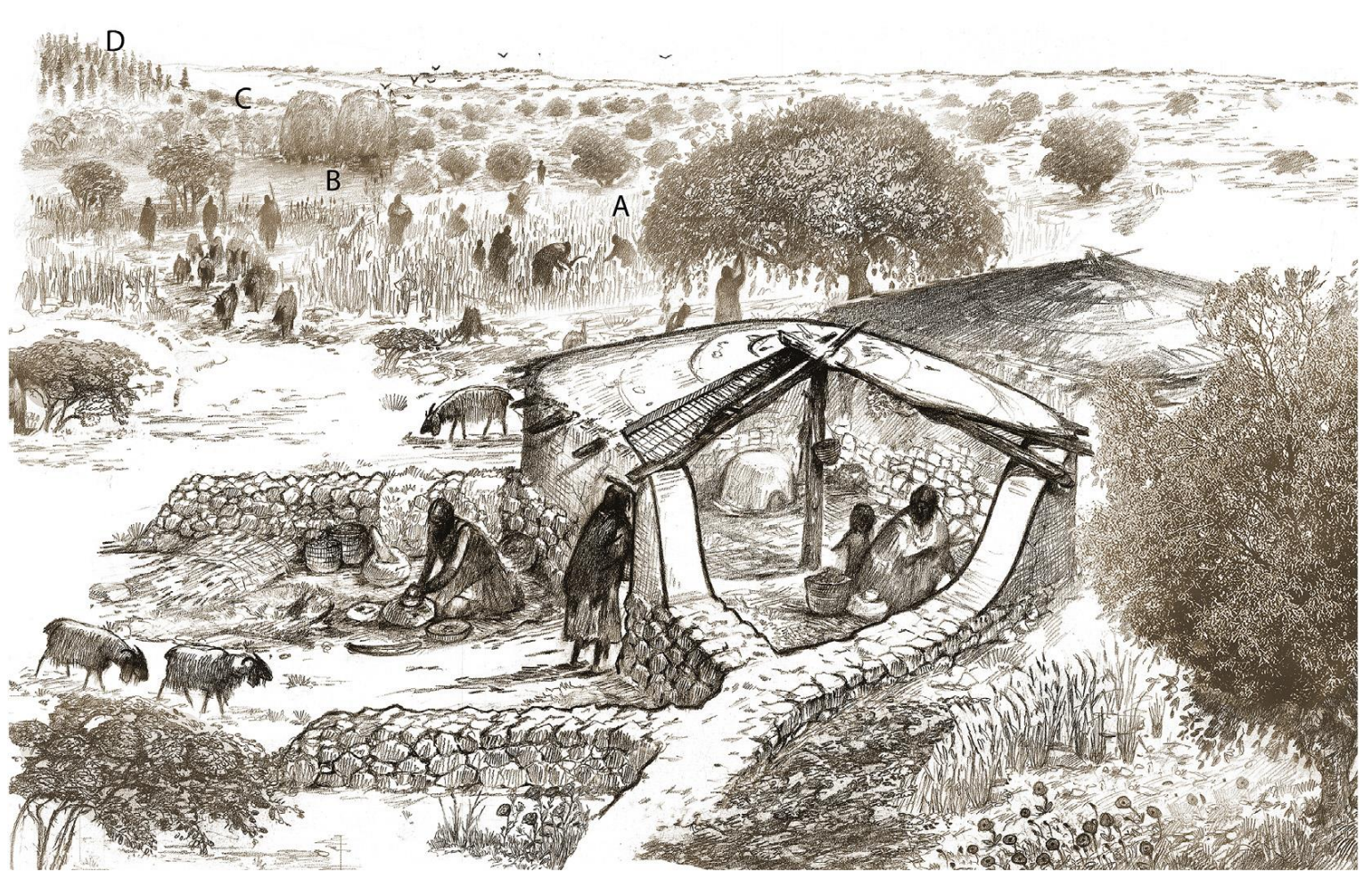

Overall, the evidence from Tell Qarassa North adds to the mosaic of plant formations attested in southwest Asia during the early Holocene (Fig. S1). The regional wood charcoal and pollen datasets highlighted east-west and north-south gradients in woodland composition not only in the southern Levant (Asouti et al., 2015), but also across southwest Asia. The evidence shows that coastal areas were dominated by 
Mediterranean deciduous and evergreen Quercus in the lowlands, and conifer forests at higher altitudes, whilst inland areas were more arid and Pistacia and Rosaceae stands predominated in woodland and woodland-steppe formations (Fig. S1, Table S5). The absence of particular taxa such as deciduous Quercus south of the Dead Sea (Fig. S1) indicates that moisture conditions were not sufficient for this tree to grow in these regions (Asouti et al., 2015), highlighting north-south gradients in the distribution of certain plant communities. This may also apply to Amygdalus, a cold-tolerant species that was rarely attested in the southern Levant during the early Holocene, but predominated along with Pistacia in inland areas starting from southern Syria up to the northern Levant, Anatolia and the Zagros (Fig. S1, Table S5). Early Holocene records show that areas that nowadays receive low precipitation (e.g. Jordan Valley) were considerably moister than at present, and allowed the development of more extensive forests. This pattern is also evidenced at Tell Qarassa North by the presence of evergreen and deciduous Quercus. Notwithstanding that early Holocene vegetationwas not stable and changed in relation to centennial-scale climatic fluctuations and anthropogenic impacts (among other factors), the type of plant formations found during this time broadly match the limits of modern-day phytogeographical regions in southwest Asia.

\subsection{The palaeoenviromental conditions at the time of cereal domestication}

The analyses of the non-woody plant macroremains (Arranz-Otaegui et al., 2016a) and microremains (Figure 2, 3 6, and 7) from Tell Qarassa North indicate that cereal cultivation was common practice since the earliest occupation phases of the site (i.e.. area XYZ phase I-IV, 10.7-10.5 ka cal. BP). The presence of cereal pollen at Tell Qarassa North suggests cultivation took place in the vicinity, probably in the lands located towards the south of the site (Arranz-Otaegui et al., 2016a; López-Sáez and López-Merino, 2005). The fact that around $30 \%$ of the cereal crops bear characteristics of domesticated species (i.e. tough-rachis) indicates that since $10.7 \mathrm{ka}$ cal. BP inhabitants cultivated both wild and domesticated emmer (T. dicoccoides/dicoccum), einkorn $\quad(T$. boeoticum/urartu/monococcum), and to a lesser extent barley (Hordeum spontaneum/vulgare) (Arranz-Otaegui et al., 2016a). This evidence contrasts with that observed at contemporary sites in the southern-central Levant, where barley is the most common species exploited (see summary in Arranz-Otaegui et al., 2016b).

It is likely that the environmental conditions around Tell Qarassa North were more humid than in the rest of the sites in the southern Levant and allowed the exploitation of 
wheat over barley. The minimum rainfall requirements for these cereals present at Tell Qarassa North is approximately $200 \mathrm{~mm}$ for Hordeum spontaneum, $250 \mathrm{~mm}$ for T. urartu, $300 \mathrm{~mm}$ for T. boeoticum and $400 \mathrm{~mm}$ for T. dicoccoides (Willcox, 2005; Heun et al., 2008). The widespread presence of emmer in the assemblage indicates that the minimum annual precipitation around 10.7-9.9 ka cal. BP must have been of around $400 \mathrm{~mm}$. This estimate is confirmed by the habitat requirements of the tree species found at the site. $Q$. ithaburensis is largely dependent on the amount of precipitation and it commonly needs annual average rainfall above $400 \mathrm{~mm}$ (Bobek, 1963; Zohary, 1973). Pistacia atlantica and Amygdalus korschinskii commonly grow in areas with average rainfall 300-400 mm per year (Bobek, 1963). The high $\Delta^{13} \mathrm{C}$ values recorded in the charcoal of Pistacia and Amygdalus from Tell Qarassa North indicate that these trees were growing in relatively wet conditions, prevalent at other early agricultural sites (Araus et al., 2014). In the case of Pistacia, the $\Delta^{13} \mathrm{C}$ values were similar to those recorded at Epipaleolithic and Neolithic sites in the northern Syria and southeastern Turkey (Araus et al., 2014), including those recorded in the second half of the Holocene (Deckers, 2016). Yet, the values found at Tell Qarassa North were slightly higher than present-day values in the region (Masi et al., 2013; Araus et al., 2014), indicating that cereal domestication took place at a time of moister environmental conditions (i.e. $>350 \mathrm{~mm}$, Traboulsi, 2013). It is also noteworthy that Pistacia and Amygdalus charcoals from the roof structure exhibited lower values in contrast to dispersed wood charcoal remains derived from fuel waste (Figure 5). These results cannot be explained by the biological age of the wood charcoal fragments analysed (i.e. deriving either from trunks or from branches) (Table S3). Moreover the available literature does not conclusively support the effect of age on the $\Delta 13 \mathrm{C}$ of the wood charcoal (Tans and Mook, 1980; Leavitt and Long, 1986; Schleser, 1992; Nguyen-Queyrens et al., 1998 ; Fotelli et al., 2009). Instead, it could be that the building materials were gathered in a different location in comparison to fuel resources, probably beyond the agricultural surroundings of the site, in less fertile locations such as those found towards the north, in the Leja area.

\subsection{The dynamics of past vegetation around $10.5-9.9 \mathrm{ka}$ cal. BP}

For around 200-300 years, plant formation around Tell Qarassa North did not suffer major changes indicating that the whole vegetation system worked in dynamic equilibrium. This means that from 10.7 to $10.5 \mathrm{ka}$ cal. BP the inflows and outflows that regulated the amount and the type of trees present in the area were balanced. The sum of 
all outflows (e.g. natural death of trees, wood gathering and fire-related activities) equalled the sum of all inflows (e.g. natural reproduction of trees, tree management activities), and therefore, allowed the different plant formation growing around Tell Qarassa North (i.e. woodlands-steppe, oak-woodlands, riparian vegetation and mountain vegetation) to maintain relatively unchanged. However, between c. 10.5 and $9.9 \mathrm{ka}$ cal. BP (phase V in area XYZ, and the upper phase in area VU), several changes occur in some of the outflows and inflows that regulate the vegetation system, in particular in those related to the climate system and the human system, leading to substantial transformations in the local and regional vegetation.

\subsubsection{Changes in the climate system}

The latest occupation phases of Tell Qarassa North dated to between 10.5 and $9.9 \mathrm{k}$ cal. BP (phase V in area XYZ and upper phase in area VU), highlight changes in the proportions of trees that are sensitive to temperature fluctuations. The pollen records show a marked decrease in thermophilous taxa such as Pistacia, Periploca, Sarcopoterium and Zizyphus and Quercus calliprinos (Figures 2 and 3). This trend is synchronous with the increase in the pollen of mesophilous trees such as Betula and Cedrus, and the first appearance in the assemblage of typically mesophilous Junglans (Figures 2 and 3). The shifts observed suggest that between 10.5 and $9.9 \mathrm{ka}$ cal. BP, cold environmental conditions established around Tell Qarassa North. Regional datasets show that centennialscale rapid climatic changes occurred during the Holocene in the Mediterranean region, and comprised changes in temperature and rainfall conditions (Mayewski et al., 2004). Based on the Glacial GISP2 non sea-salt (nss) potassium $\left[\mathrm{K}^{+}\right]$concentration record, Weninger et al. (2009) suggested that one of the coldest events during the last 50,000 years occurred at around $10.2 \mathrm{ka} \mathrm{cal}$ BP in the eastern Mediterranean. The $10.2 \mathrm{ka} \mathrm{cal}$. BP event was previously identified in other regions of the Northern Hemisphere (Bond et al., 1997; Rasmussen et al., 2007; Cai et al., 2008), however, so far, it has not been identified in Mediterranean pollen records. This rapid climatic change has been associated to a major interruption in the sequence of settlements in the northern Levant and it has been referred to as possible trigger for the abandonment of several Pre-Pottery Neolithic sites (Borrell et al., 2015). At Tell Qarassa North, the reduction of thermophilous species opposed to mesophilous species is a possible signal of a climatic change contemporary with the 10.2 ka cal. BP event. Most of the mesophilous and thermophilous species that show changes during this time were probably growing at a considerable distance from the site (see 
section 6.1.), and therefore, human factors can be excluded as possible explanations for their diminution/increase. Furthermore, during other cold rapid climatic changes such as the $8.2 \mathrm{ka}$ cal. BP, a decrease in thermophilous species such as Quercus calliprinos has been recorded in several pollen records in the Mediterranean area (Rossignol-Strick, 1999; Pross et al., 2009). Besides, most of the mesophilous and thermophilous species that showed changes during this time were probably growing at a considerable distance from the site (see Section 6.1.), and therefore, human factors can be excluded as possible explanations. Considering this, it is likely that the establishment of colder environmental conditions between 10.5 and $9.9 \mathrm{ka}$ cal. BP acted as an outflow on the flora of the Jabal alArab region reducing the extension of thermophilous taxa.

Besides this, temperature fluctuations could have acted as a reinforcing feedback loop, and enhanced further transformations in the local and regional vegetation. Decrease temperatures commonly result in higher snow accumulations and ice melt water, which condition the growth of alluvial fans in valley bottoms, and the rise in the water table of rivers, lakes and water ponds. In Europe, several studies have identified hydrological changes (e.g. floods) as a consequence of the $8.2 \mathrm{ka}$ cal. BP cooling episode (Alley and Agustsfottir, 2005; Hughes et al. 2000; Magny et al., 2003). In the Anatolian Plateau, the expansion of alluvial fans around $9.5 \mathrm{ka} \mathrm{cal}$. BP (Boyer et al. 2006) were referred to as a possible signal of a climatic change contemporary with the cold $9.2 \mathrm{ka}$ cal BP event (Berger et al., 2016). In Cyprus, flood episodes that caused strong upstream erosion (Devillers, 2005), as well as surface erosion and torrential discharges were attested around $8.5 \mathrm{ka}$ cal. BP and $8.1 \mathrm{ka}$ cal. BP (Berger et al., 2016), which could be linked to $8.2 \mathrm{ka}$ cal. BP event. In the Lake Van, high water tables associated to increased sedimentation and mineral content were recorded also around 8.4-8.2 ka cal. BP (Lemcke and Sturm, 1997). Considering that hygrophilous plants represent edaphic communities that depend on ground moisture and water availability (Zohary, 1973), changes in the water table of the nearby water ponds and springs caused by the establishment of colder environmental conditions could have also altered the extent to which this plant formations grew in the vicinity. This hypothesis would explain the synchronous spread of mesophilous species and the development of hygrophilous and meadow steppe attested taxa between 10.5 and 9.9 ka cal. BP at Tell Qarassa North (Figures 2 and 3).

An additional factor that could have contributed to the spread of hygrophilous plants has to do with the other main element that regulates plant growth in the climate system that is rainfall. The isotope record from Tell Qarassa North indicated centurial changes in the 
isotopic content of the wood charcoal samples studied. In area XYZ, Pistacia and Amygdalus $\Delta^{13} \mathrm{C}$ values decreased from phase I to phase IV, indicating that the second destruction of the site (phase IV) occurred at the time of dry environmental conditions in comparison to earlier occupation phases, and which coincide with maximum values for dry-tolerant Artemisia in the pollen samples from phase IV (Figure 2). This period was followed by increased values during the last phases of the site (phase V and VI in XYZ and upper and lower phase in VU), indicating the re-establishment of wet conditions. At Tell Qarassa North, the spread of wetland taxa in phase V of area XYZ and upper phase of area VU is coincidental with the disappearance of Artemisia (Figures 2 and 3), a common indicator of dryness in the pollen records (Rossignol-Strick, 1995) and increase in Poaceae (e.g., from 5-12\% to 13-19\% in area VU, Figures 2 and 3). The increase in Poaceae pollen at the expense of Artemisia is suggestive of reduced summer drought or increase summer precipitation. In previous studies, high percentage of Poaceae pollen in deep-core pollen records from the Arabo-Persian Gulf were interpreted as evidence of reduced extreme summer drought around $8.0 \mathrm{ka}$ cal. BP (el-Moslimany, 1983). The evidence would thus indicate that between 10.5 and $9.9 \mathrm{ka}$ cal. BP environmental conditions around Tell Qarassa North not only turned colder, but also moister. This is in accordance with the regional datasets from the Mediterranean area, which indicate that after the $10.2 \mathrm{ka}$ cal. $\mathrm{BP}$, around 10-8.6 ka cal. BP, extremely wet conditions prevailed, referred to as the Levantine Moist Period (LMP). These conditions have been best documented in the Dead Sea (Weninger et al., 2009; Arz et al., 2003b; Migowski et al., 2006), located around 150 $\mathrm{km}$ to the west of Tell Qarassa North. The stable carbon isotopes from Soreq Cave (Israel) indicate that during this time regional rainfall could have been twice higher than the present-day average (Bar-Matthews et al., 2000). Recent stable carbon isotope analyses of archaeological plant remains from Neolithic sites in the Middle Euphrates confirm a peak in humid conditions between 10.0 and $8.0 \mathrm{ka}$ cal. BP (Araus et al., 2014). It is thus possible that increased rainfall conditions in the Jabal al-Arab produced changes in the water tables of water ponds and lakes located in the plain, and this could have contributed to the development of wetland vegetation around Tell Qarassa North.

\subsubsection{Changes in the human system}

The pollen records from Tell Qarassa North show a remarkable decrease in arboreal pollen between 10.5 and $9.9 \mathrm{ka}$ cal. BP (Figures 2 and 3). In area XYZ, Quercus ithaburensis, Quercus calliprinos and Pistacia pollen values decreased from 15-25\% 
920 (phases I-IV) to 6-11\% (phase V), from 7-15\% (phases I-IV) to 2-4\% (phase V) and from $4-7 \%$ (phases I-IV) to $2-4 \%$ (phase $\mathrm{V}$ ) respectively, and this decrease is also attested in area VU (Figures 2 and 3). Whilst the evidence does not suggest massive deforestation, it does indicate a shift towards an open landscape and overall lower tree cover than in previous periods. The decrease in Mediterranean vegetation comprising thermophilous species such as $Q$. calliprinos could have been triggered by changes in the climate system (section 6.3.1). However, the evidence shows that changes in the arboreal cover occurred at the time of increased evidence for anthropogenic pressures (Figures 2 and 3). This means that plant formation that grew in the immediate vicinity of the site (e.g. Pistacia, $Q$. ithaburensis) would have been regulated by additional inflows and outflows associated to the anthropogenic system.

The pollen records for the latest occupation phases of the site (phase V in area XYZ, and upper phase in area VU) indicate a sudden rise in anthropozoogenic taxa (Chenopodiaceae, Plantago lanceolata, Rumex acetosa, $R$. acetosella), which refer to plants related to grazed pastures (Behre, 1981); coprophilous fungi (Sordariaceae, Chaetomium), which commonly develop on dung (van Geel, 2001). This indicates that between 10.5 and $9.9 \mathrm{ka}$ cal BP, coinciding with the development of agropastoral societies in southwest Asia (Asouti and Fuller, 2012, 2013; Zeder, 2011), herding activities intensified in the area around Tell Qarassa North. The preliminary analyses of the faunal remains from Tell Qarassa North revealed the primary exploitation of goat (Capra format aegagrus) during all the occupations (L. Gourichon in Ibáñez et al., 2010), along with a large spectrum of animal taxa comprising other ungulates like the gazelle, the aurochs, the wild boar and the Mesopotamian fallow deer, and the hare and various species of carnivores and birds as small game (see Table S6). Sheep bones have not been clearly identified and the goat remains show the same size range (though slightly larger in average) that the goat populations from the late Early and Middle PPNB levels of Tell Aswad where evidence of herding was attested (Helmer and Gourichon 2008, 2016). If the domestic status of the goats from Tell Qarassa cannot be asserted from metrical or morphological criteria or kill-off profiles, due to the lack of data, the results provided by the study of NPPs shed new light on this question. The regular occurrence of coprophilous fungi (Sordariaceae) throughout the sequence indicates the prevalence of ungulate dung around and within the habitat that cannot be explained solely by incidental deposits from the intestinal contents of wild animals butchered in the surroundings. In this sense, these data strongly suggest that at least part of the goats were herded near Tell Qarassa North, at 
954 a time where early domestication of the bezoar goat was demonstrated in Northern 955 Mesopotamia (Peters et al., 2005). It must be considered that compared to sheep, goats are 956 preferentially browsers and can remove tree seedlings, reducing the rates of natural 957 woodland regeneration (Janis, 2008; Skarpe and Hester 2008). Several researchers 958 suggested that overgrazing was partially responsible for the reduction in plant cover in 959 regions associated to the emergence of sheep/goat pastoralism, resulting in changes in 960 settlement patterns as early as the PPNB (Falconer and Fall, 1995; Grigson, 1995; Köhler961 Rollefson, 1988; Köhler-Rollefson and Rollefson, 1990; Simmons, 2000; Tchernov and 962 Horwitz, 1990). Despite it is difficult to test, it is possible that increased herding activities 963 between 10.5 and $9.9 \mathrm{ka}$ cal. BP acted as an outflow and reduced the chances for local trees such as Pistacia or deciduous Quercus to reproduce. This change, coupled with the 965 shift to colder environmental conditions (section 6.3.1), would have hindered the maintenance of the arboreal cover in proportions similar to those attested in previous phases (i.e. I-IV in area XYZ, and lower-phase in area VU).

970

Additionally, the evidence between 10.5 and $9.9 \mathrm{ka}$ cal. BP shows a marked increase carbonicolous fungi such as Chaetomium, a common indicator of anthropogenic fires (López-Sáez et al., 1998; van Geel et al., 2003; López-Sáez and López-Merino 2007); as well as increased Glomus values, which have been associated to erosive processes related

972 to the anthropic dynamics in the immediate environment of archaeological sites (López973 Sáez et al., 2000). The evidence thus indicates increased firing activities in the area. The 974 purpose of theses fires is difficult to asses, but fire management is in general associated 975 with hunter-gatherers, pastoralists and cultivators that aim to maintain open savannah-type landscapes with grasslands and trees suitable for agropastoral activities (Roberts, 2002), and Tell Qarassa North the evidence coincided with the time when herding activities intensified and arboreal cover reduced. Regional datasets indicate that grasslands reached maximum values during the early Holocene and dry-season burning was one of the main factors regulating these grass-parkland ecosystems (Turner et al., 2010). Grasses represent competitors for the development of Quercus seedlings and they can hamper the expansion of oak-woodlands (see recent review by Asouti and Kabukcu, 2014). In the Mediterranean region, low-intensity ground fires are common in the summer dry season, and favour the development of wild cereal grasses (Zohary and Hopf, 2000; Grove and Rackham 2001). It is thus likely that increased fire-related and herding activities, as well as additional changes in the climate system, all contributed as direct or indirect factors to the decline of the local arboreal cover between 10.5 and $9.9 \mathrm{ka}$ cal. BP. 


\section{Conclusions}

990

The analyses carried out at Tell Qarassa North show the importance of considering multiple datasets (e.g. plant macro and microremains) to reconstruct past vegetation and environmental conditions in southwest Asia. The multi-proxy analyses at the site have provided high-resolution data to characterise the local and regional vegetation and its evolution at the time when morphologically domesticated cereals appear and developed in southern Syria (10.7-9.9 ka cal. BP). The combination of wood charcoal and pollen evidence indicates that Tell Qarassa North was located within the Irano-Turanian and Mediterranean phytogeographical regions. The local vegetation comprised woodlandsteppe components and riparian taxa, whilst Mediterranean oak-woodlands and coniferous forests could have grown at further distance, in the mountain areas of the Jabal al-Arab located to the east of the site. The results overall indicate that considerably moister conditions than at present prevailed around Tell Qarassa North and the Jabal al-Arab, which is consistent with climatic and environmental conditions during the early Holocene (Robinson et al., 2006; Weninger et al., 2009). Furthermore, the evidence shows that the site was located also in amore humid area in comparison to coeval sites in the southern Levant, and could explain why the inhabitants of site exploited predominantly wheat species opposed to barley. Cereal domestication in southern Syria occurred at a time when vegetation, climate and human groups interacted in dynamic equilibrium and the environment was characterised by mild winters (probably frost-free) and hot summers, and an average rainfall of around $400 \mathrm{~mm}$ per year.

Slightly later, between 10.5 and $9.9 \mathrm{ka}$ cal. BP, the inflows and outflows that regulated vegetation and that were dependant upon climate and human activities were altered, and resulted in substantial transformations in the local and regional vegetation. Our results provide evidence for the spread of mesophilous and hygrophilous taxa during this time, and suggest the establishment of colder and wetter environmental conditions than today. These fluctuations occurred during a broad time frame (from 10.5 to $9.9 \mathrm{ka}$ cal. BP) and while they cannot be directly correlated with specific RCCs (e.g. the $10.2 \mathrm{ka} \mathrm{cal}$. BP), it is likely that they were triggered by shifts in the inflows and outflows associated to the climate system (e.g. rainfall, temperature). Considering that climatic anomalies vary in time, space, intensity and type of signal, further investigations are needed to compare the 
from this, pollen records from Tell Qarassa North showed increased fire-related and herding activities from 10.5 to $9.9 \mathrm{ka}$ cal. BP, which along with changes in the climatic conditions, could have enhanced the spread of grasses and the shift to an open landscape with less arboreal cover. At this regard, more studies are necessary not only to identify the presence of anthropogenic impacts in the wood charcoal and pollen records, but also to fully evaluate how human activities altered local plant formations beyond linear models that link human activities to the decrease of the arboreal cover and deforestation.

Overall, in this work we show that changes in the past vegetation were complex in that they involved elements of different systems acting synergistically, and causing plantspecific responses. This means that single factor explanations (i.e., climatic or anthropogenic) of plant change during the Holocene will fail to recognize the diversity and complexity of the interactions that commonly regulate plant ecosystems.

\section{Acknowledgments}

This work is dedicated to Lydia Zapata, for her support, encouragement and commitment to Tell Qarassa North project. The wood charcoal analyses were conducted by Amaia Arranz-Otaegui during her PhD research at the University of the Basque Country and with the financial support of the Basque Government (Pre-doctoral grant number: BFI.09.249) and the UPV/EHU: Research Group IT622-13/UFI 11-09. Marta Portillo is part of the Prehistory Consolidated Research Team at the UPV/EHU IT-622-13. Her research is currently funded by the EU Horizon 2020 Marie Sklodowska-Curie action MICROARCHAEODUNG (grant number: H2020-MSCA-IF-2015-702529). Andrea Balbo has worked on this paper on a Research Fellowship from the Alexander von Humboldt Foundation. The Qarassa project was carried out thanks to the authorisation of the General Directorate of Antiquities and Museums of Syria. The project was funded by the Spanish Institute of Cultural Heritage (Ministry of Culture), the Ministry of Science and Innovation (R+D Projects: BHA2003-09685-CO2-01, HUM2007-66128-C02-01, HUM2007-66128-C02-02 and HAR2013-47480-P), and the Government of Catalonia (EXCAVA2006 Programme), Gerda Henkel, Palarq and Shelby White-Leon Levy Foundations.

\section{Supplementary data}


Table S1. Available radiocarbon dates for Tell Qarassa North, area XYZ and VU. Radiocarbon determinations were performed in charcoal samples at Beta Analytic Inc. (Miami, Florida, USA) and Centro Nacional de Aceleradores (Sevilla, Spain). Radiocarbon ages were calibrated with OxCalv4.2.2 (Bronk-Ramsey, 2009) using the IntCal09 calibration curve (Reimer et al., 2009).

\begin{tabular}{|c|c|c|c|c|c|c|c|c|c|}
\hline Area & $\begin{array}{l}\text { Phase/ } \\
\text { Group }\end{array}$ & Space & Unit & $\begin{array}{c}\text { Phase } \\
\text { Interpretation }\end{array}$ & Reference & $14 C$ BP & cal BP & cal BC & Dated material \\
\hline \multirow{12}{*}{$\begin{array}{c}\text { XYZ- } \\
67 / 68 / 69\end{array}$} & $\mathbf{I}$ & $\mathrm{B}$ & 52C & $1^{\circ}$ Occupation & CNA - 1355 & $9185 \pm 40$ & $10487-10244$ & $8538-8295$ & T. dicoccoides/dicoccum \\
\hline & \multirow{4}{*}{ II } & \multirow[b]{2}{*}{$\mathrm{A}$} & \multirow[b]{2}{*}{57} & \multirow{4}{*}{$1^{\circ}$ Destruction } & CNA - 1065 & $9300 \pm 45$ & 10651-10298 & $8702-8349$ & $\begin{array}{l}\text { Pistacia sp. (Branch } \\
\text { BB48) }\end{array}$ \\
\hline & & & & & Beta - 290929 & $9340 \pm 50$ & 10700-10407 & $8751-8458$ & $\begin{array}{c}T . \\
\text { boeoticum/monococcum }\end{array}$ \\
\hline & & A & 74 & & - & - & - & - & - \\
\hline & & $\mathrm{B}$ & $52 \mathrm{~B}$ & & - & - & - & - & - \\
\hline & \multirow{2}{*}{ III } & A & $24 b ; 25$ & \multirow{2}{*}{$2^{\circ}$ Occupation } & CNA - 1353 & $9252 \pm 38$ & $10555-10279$ & $8606-8330$ & $\begin{array}{c}T . \\
\text { boeoticum/monococcum }\end{array}$ \\
\hline & & B & 52 & & CNA - 1354 & $9292 \pm 48$ & 10648-10291 & $8699-8342$ & $\begin{array}{c}T . \\
\text { boeoticum/monococcum }\end{array}$ \\
\hline & \multirow{2}{*}{ IV } & $\mathrm{A}$ & $24 ; 36 ; 37$ & \multirow{2}{*}{$2^{\circ}$ Destruction } & - & - & - & - & - \\
\hline & & $\mathrm{B}$ & 14 & & - & - & - & - & - \\
\hline & \multirow{2}{*}{$\mathbf{V}$} & $\mathrm{A}$ & 21 & Abandonment & Beta -272103 & $9320 \pm 50$ & $10683-10301$ & $8734-8352$ & Large-seeded Poaceae \\
\hline & & A & $\mathbf{3 4} ; 18 ; 5 ; 6$ & Cemetery & Beta - 262213 & $9100 \pm 60$ & $10480-10178$ & $8531-8229$ & T. dicoccoides/dicoccum \\
\hline & VI & A & $15 ; 3 ; 4$ & Surface layers & Beta - 277177 & $9300 \pm 50$ & $10653-10296$ & $8704-8347$ & Triticum spp. \\
\hline \multirow{3}{*}{ VU-67 } & & \multirow{2}{*}{ Lower } & \multirow{2}{*}{$\mathbf{1 4 ; 1 5 ; 1 0 ~}$} & \multirow{2}{*}{ Lower phase } & CNA-3129 & $9192 \pm 40$ & $10490-10246$ & $8541-8297$ & Leguminosae seed \\
\hline & & & & & Beta - 402487 & $9100 \pm 30$ & $10493-10200$ & $8344-8251$ & Wood charcoal \\
\hline & & Upper & $4 ; 3$ & Upper phase & Beta - 274098 & $9030 \pm 60$ & $10368-9919$ & $8419-7970$ & Leguminosae seed \\
\hline
\end{tabular}


Table S2. Carbon isotope discrimination $\left(\Delta^{13} \mathrm{C}\right)$ values of the Pistacia and Amygdalus wood charcoal remains from Tell Qarassa North. Sample reference and location as well as dating, growth-ring curvature and carbon isotope composition $\left(\delta^{13} \mathrm{C}_{\text {sample}}\right)$ values are listed for each sample.

Spaces A and B belong to the XYZ area, whereas the upper and lower phases refer to the VU area.

\begin{tabular}{|c|c|c|c|c|c|c|c|c|c|c|c|}
\hline $\begin{array}{l}\text { Sample } \\
\mathbf{N}^{\mathbf{0}}\end{array}$ & $\begin{array}{l}\text { Sample } \\
\text { ID }\end{array}$ & Layer & $\begin{array}{l}\text { Growth-ring } \\
\text { Curvature }\end{array}$ & $\begin{array}{l}\text { Pistacia } \\
\text { sp. }\end{array}$ & $\begin{array}{c}\text { Amygdalus } \\
\text { sp. }\end{array}$ & Reference & Data BP & $\% \mathrm{C}$ & $\begin{array}{c}\delta^{13} C_{\text {sample }} \\
(\%)\end{array}$ & $\begin{array}{c}\delta^{13} \mathrm{C}_{\text {air }} \\
(\%)\end{array}$ & $\begin{array}{r}\Delta^{13} \mathrm{C} \\
(\%) \\
\end{array}$ \\
\hline 1 & $\begin{array}{l}\text { Z67 } \\
\text { Y67 }\end{array}$ & Space A, phase IV & weak & $X$ & & & & 64.71 & -24.67 & -6.73 & 18.40 \\
\hline 2 & $\begin{array}{l}\mathrm{Z} 67 \mathrm{D} / \mathrm{E} \\
5\end{array}$ & Space A, phase IV & weak & $X$ & & & & 65.19 & -24.88 & -6.73 & 18.61 \\
\hline 8 & Y68 & Space A, phase IV & moderate & & $X$ & & & 62.98 & -25.08 & -6.73 & 18.82 \\
\hline 12 & Y67 & Space A, phase IV & strong & $X$ & & & & 64.81 & -23.37 & -6.73 & 17.04 \\
\hline 14 & Y67 C2 & Space A, phase IV & - & $X$ & & & & 65.57 & -22.79 & -6.73 & 16.44 \\
\hline 15 & Y67 D2 & Space A, phase IV & moderate & & $\mathrm{X}$ & & & 64.17 & -24.88 & -6.73 & 18.62 \\
\hline 17 & Y68 & Space A, phase IV & weak & $X$ & & & & 65.53 & -25.11 & -6.73 & 18.85 \\
\hline 51 & $\begin{array}{l}\text { Y67 } \\
\text { C/D1 }\end{array}$ & Space A, phase IV & strong & $\mathrm{X}$ & & & & 67.63 & -25.07 & -6.73 & 18.82 \\
\hline 24 & Y67 E2 & Space A, phase IV & weak & $X$ & & & & 62.06 & -24.64 & -6.73 & 18.37 \\
\hline 3 & Y67 & Space A, phase VI & moderate & & $X$ & Beta - 277177 & $9300 \pm 50$ & 61.96 & -25.59 & -6.73 & 19.35 \\
\hline 11 & Y67 & Space A, phase VI & weak & & $X$ & Beta - 277177 & $9300 \pm 50$ & 65.46 & -24.86 & -6.73 & 18.58 \\
\hline 20 & Y67 E2 & Space A, phase VI & - & & $X$ & Beta - 277177 & $9300 \pm 50$ & 63.43 & -25.45 & -6.73 & 19.21 \\
\hline 5 & Y68 & Space A, phase VI & - & $X$ & & Beta - 277177 & $9300 \pm 50$ & 63.95 & -24.49 & -6.73 & 18.20 \\
\hline 6 & Y67 & Space A, phase VI & weak & & $X$ & Beta - 277177 & $9300 \pm 50$ & 63.33 & -24.15 & -6.73 & 17.84 \\
\hline 10 & Y67 & Space A, phase VI & moderate & & $X$ & Beta - 277177 & $9300 \pm 50$ & 62.98 & -25.96 & -6.73 & 19.74 \\
\hline 23 & Y67 E2 & $\begin{array}{l}\text { Space A, phase V } \\
\text { (cemetery) }\end{array}$ & strong & & $X$ & Beta - 262213 & $9100 \pm 60$ & 64.20 & -24.97 & -6.72 & 18.71 \\
\hline 13 & Y67 C3 & $\begin{array}{l}\text { Space A, phase V } \\
\text { (cemetery) }\end{array}$ & strong & & $X$ & Beta - 262213 & $9100 \pm 60$ & 65.83 & -25.66 & -6.72 & 19.43 \\
\hline
\end{tabular}




\begin{tabular}{|c|c|c|c|c|c|c|c|c|c|c|c|}
\hline $\begin{array}{l}\text { Sample } \\
\mathbf{N}^{\mathbf{o}} \\
\end{array}$ & $\begin{array}{l}\text { Sample } \\
\text { ID }\end{array}$ & Layer & $\begin{array}{l}\text { Growth-ring } \\
\text { Curvature }\end{array}$ & $\begin{array}{l}\text { Pistacia } \\
\text { sp. }\end{array}$ & $\begin{array}{c}\text { Amygdalus } \\
\text { sp. }\end{array}$ & Reference & Data BP & $\% \mathrm{C}$ & $\begin{array}{c}\delta^{13} C_{\text {sample }} \\
(\%)\end{array}$ & $\begin{array}{c}\delta^{13} C_{a i r} \\
(\% o) \\
\end{array}$ & $\begin{array}{c}\Delta^{13} \mathrm{C} \\
(\% \text { ) }\end{array}$ \\
\hline 18 & Y67 E2 & $\begin{array}{l}\text { Space A, phase V } \\
\text { (abandonment) }\end{array}$ & weak & & $X$ & Beta - 272103 & $9320 \pm 50$ & 62.56 & -24.87 & -6.74 & 18.60 \\
\hline 9 & Y67 D3 & $\begin{array}{l}\text { Space A, phase V } \\
\text { (abandonment) }\end{array}$ & weak & & $X$ & Beta - 272103 & $9320 \pm 50$ & 95.05 & -24.58 & -6.74 & 18.29 \\
\hline 4 & V67 & Upper phase & weak & $\mathrm{X}$ & & Beta - 274098 & $9030 \pm 60$ & 64.74 & -25.29 & -6.70 & 19.07 \\
\hline 7 & V67 & weaker phase & weak & $\mathrm{X}$ & & Beta - 402487 & $9100 \pm 30$ & 63.28 & -25.30 & -6.70 & 19.09 \\
\hline 16 & V67 & Upper phase & moderate & $X$ & & Beta - 274098 & $9030 \pm 60$ & 64.95 & -25.53 & -6.70 & 19.32 \\
\hline 22 & V67 & Upper phase & weak & $X$ & & Beta - 274098 & $9030 \pm 60$ & 65.22 & -25.69 & -6.70 & 19.49 \\
\hline 25 & V67 & weaker phase & weak & & $X$ & CNA-3129 & $9192 \pm 40$ & 62.70 & -25.00 & -6.70 & 18.76 \\
\hline 50 & Y67 E3 & Space A, phase III & weak & $\mathrm{X}$ & & CNA1353 & $9252 \pm 38$ & 55.78 & -22.57 & -6.73 & 16.21 \\
\hline 52 & Y67 E4 & Space A, phase III & weak & & $\mathrm{X}$ & CNA1353 & $9252 \pm 38$ & 64.84 & -23.61 & -6.73 & 17.29 \\
\hline 55 & Y67 E1 & Space A, phase III & weak & & $\mathrm{X}$ & CNA1353 & $9252 \pm 38$ & 64.34 & -25.78 & -6.73 & 19.56 \\
\hline 56 & Y68 A4 & Space A, phase III & - & & $X$ & CNA1353 & $9252 \pm 38$ & 61.79 & -25.31 & -6.73 & 19.07 \\
\hline 57 & Y68 A1 & Space A, phase III & weak & $\mathrm{X}$ & & CNA1353 & $9252 \pm 38$ & 68.08 & -24.44 & -6.73 & 18.16 \\
\hline 58 & Y67 D1 & Space A, phase III & weak & & $X$ & CNA1353 & $9252 \pm 38$ & 63.20 & -25.16 & -6.73 & 18.91 \\
\hline 59 & Y67 D2 & Space A, phase III & weak & $\mathrm{X}$ & & CNA1353 & $9252 \pm 38$ & 65.53 & -25.18 & -6.73 & 18.93 \\
\hline 60 & Y68 A2 & Space A, phase III & weak & $X$ & & CNA1353 & $9252 \pm 38$ & 64.87 & -24.61 & -6.73 & 18.33 \\
\hline 61 & Y68 A2 & Space A, phase III & weak & $\mathrm{X}$ & & CNA1353 & $9252 \pm 38$ & 66.20 & -24.86 & -6.73 & 18.60 \\
\hline 62 & Y67 E3 & Space A, phase III & weak & & $X$ & CNA1353 & $9252 \pm 38$ & 56.57 & -23.86 & -6.73 & 17.56 \\
\hline 65 & Y67 E3 & Space A, phase II & - & & $X$ & Beta - 290929 & $9340 \pm 50$ & 64.44 & -25.18 & -6.74 & 18.91 \\
\hline 66 & Y67 C3 & Space A, phase III & weak & $X$ & & CNA1353 & $9252 \pm 38$ & 65.49 & -25.34 & -6.73 & 19.10 \\
\hline 79 & Y67 D3 & Space A, phase III & weak & & $\mathrm{X}$ & CNA1353 & $9252 \pm 38$ & 62.62 & -25.28 & -6.73 & 19.04 \\
\hline 81 & Y67 D2 & Space A, phase III & weak & $X$ & & CNA1353 & $9252 \pm 38$ & 61.88 & -26.50 & -6.73 & 20.31 \\
\hline 82 & Y67 D3 & Space A, phase III & - & $X$ & & CNA1353 & $9252 \pm 38$ & 58.14 & -22.21 & -6.73 & 15.83 \\
\hline
\end{tabular}




\begin{tabular}{|c|c|c|c|c|c|c|c|c|c|c|c|}
\hline $\begin{array}{l}\text { Sample } \\
\mathbf{N}^{\mathbf{0}}\end{array}$ & $\begin{array}{l}\text { Sample } \\
\text { ID }\end{array}$ & Layer & $\begin{array}{l}\text { Growth-ring } \\
\text { Curvature }\end{array}$ & $\begin{array}{l}\text { Pistacia } \\
\text { sp. }\end{array}$ & $\begin{array}{c}\text { Amygdalus } \\
\text { sp. }\end{array}$ & Reference & Data BP & $\% \mathrm{C}$ & $\begin{array}{c}\delta^{13} C_{\text {sample }} \\
(\%)\end{array}$ & $\begin{array}{c}\delta^{13} C_{a i r} \\
(\%)\end{array}$ & $\begin{array}{l}\Delta^{13} \mathrm{C} \\
(\% \text { o) }\end{array}$ \\
\hline 84 & $\begin{array}{l}\text { Y67 } \\
\text { C/D1 }\end{array}$ & Space A, phase III & weak & $X$ & & CNA1353 & $9252 \pm 38$ & 64.62 & -24.16 & -6.73 & 17.87 \\
\hline 86 & Y67 C1 & Space A, phase III & weak & $X$ & & CNA1353 & $9252 \pm 38$ & 58.06 & -22.73 & -6.73 & 16.38 \\
\hline 87 & Y67 D2 & Space A, phase III & weak & $X$ & & CNA1353 & $9252 \pm 38$ & 52.43 & -24.18 & -6.73 & 17.89 \\
\hline 89 & Y67 E3 & Space A, phase III & - & $X$ & & CNA1353 & $9252 \pm 38$ & 57.85 & -23.37 & -6.73 & 17.04 \\
\hline 90 & Y67 E1 & Space A, phase III & - & $\mathrm{X}$ & & CNA1353 & $9252 \pm 38$ & 57.16 & -25.12 & -6.73 & 18.87 \\
\hline 91 & Y67 E3 & $\begin{array}{l}\text { Space A, phase II, } \\
\text { roof }\end{array}$ & - & $X$ & & Beta - 290929 & $9340 \pm 50$ & 61.46 & -23.40 & -6.74 & 17.06 \\
\hline 94 & Y67 E2 & $\begin{array}{l}\text { Space A, phase II, } \\
\text { roof }\end{array}$ & weak & $X$ & & Beta - 290929 & $9340 \pm 50$ & 53.32 & -24.37 & -6.74 & 18.07 \\
\hline 95 & Y67 E2 & $\begin{array}{l}\text { Space A, phase II, } \\
\text { roof }\end{array}$ & weak & $X$ & & Beta - 290929 & $9340 \pm 50$ & 59.98 & -24.38 & -6.74 & 18.08 \\
\hline 96 & Y67 D2 & $\begin{array}{l}\text { Space A, phase II, } \\
\text { roof (post) }\end{array}$ & weak & $X$ & & Beta - 290929 & $9340 \pm 50$ & 55.45 & -25.89 & -6.74 & 19.66 \\
\hline 75 & $\begin{array}{l}\text { Y67 } \\
\text { E/D1 }\end{array}$ & $\begin{array}{l}\text { Space A, phase III } \\
\text { (pit) }\end{array}$ & weak & $X$ & & CNA1353 & $9252 \pm 38$ & 64.66 & -24.80 & -6.73 & 18.54 \\
\hline 76 & $\begin{array}{l}\text { Y67 } \\
\text { E/D1 }\end{array}$ & $\begin{array}{l}\text { Space A, phase III } \\
\text { (pit) }\end{array}$ & weak & $X$ & & CNA1353 & $9252 \pm 38$ & 60.52 & -25.01 & -6.73 & 18.76 \\
\hline 54 & X68 B1 & Space B, phase III & weak & $X$ & & CNA1354 & $9292 \pm 48$ & 63.99 & -25.85 & -6.73 & 19.63 \\
\hline 63 & Y68 D5 & Space B, phase III & weak & $X$ & & CNA1354 & $9292 \pm 48$ & 61.72 & -26.85 & -6.73 & 20.67 \\
\hline 64 & Y68 C5 & Space B, phase III & moderate & $X$ & & CNA1354 & $9292 \pm 48$ & 64.92 & -24.95 & -6.73 & 18.68 \\
\hline 77 & X69 A1 & Space B, phase III & weak & $X$ & & CNA1354 & $9292 \pm 48$ & 62.76 & -25.46 & -6.73 & 19.22 \\
\hline 92 & Y68 C4 & Space B, phase III & weak & $X$ & & CNA1354 & $9292 \pm 48$ & 64.14 & -25.75 & -6.73 & 19.52 \\
\hline 93 & Y68 E4 & Space B, phase III & weak & & $X$ & CNA1354 & $9292 \pm 48$ & 62.70 & -26.52 & -6.73 & 20.33 \\
\hline 68 & Y68 B5 & Space B, phase III & weak & $X$ & & CNA1354 & $9292 \pm 48$ & 61.49 & -25.66 & -6.73 & 19.42 \\
\hline
\end{tabular}




\begin{tabular}{|c|c|c|c|c|c|c|c|c|c|c|c|}
\hline $\begin{array}{l}\text { Sample } \\
\mathbf{N}^{\mathbf{0}} \\
\end{array}$ & $\begin{array}{l}\text { Sample } \\
\text { ID }\end{array}$ & Layer & $\begin{array}{l}\text { Growth-ring } \\
\text { Curvature }\end{array}$ & $\begin{array}{l}\text { Pistacia } \\
\text { sp. }\end{array}$ & $\begin{array}{c}\text { Amygdalus } \\
\text { sp. }\end{array}$ & Reference & Data BP & $\% \mathrm{C}$ & $\begin{array}{c}\delta^{13} C_{\text {sample }} \\
(\%)\end{array}$ & $\begin{array}{c}\delta^{13} \mathrm{C}_{\text {air }} \\
(\%)\end{array}$ & $\begin{array}{r}\Delta^{13} \mathrm{C} \\
(\%)\end{array}$ \\
\hline 69 & Y68 C5 & Space B, phase III & weak & $\mathrm{X}$ & & CNA1354 & $9292 \pm 48$ & 62.94 & -24.51 & -6.73 & 18.22 \\
\hline 71 & X68 C1 & Space B, phase III & weak & & $X$ & CNA1354 & $9292 \pm 48$ & 61.63 & -25.55 & -6.73 & 19.31 \\
\hline 73 & X68 E1 & Space B, phase III & weak & $X$ & & CNA1354 & $9292 \pm 48$ & 62.65 & -26.57 & -6.73 & 20.37 \\
\hline 83 & Y68 B4 & Space B, phase III & weak & & $X$ & CNA1354 & $9292 \pm 48$ & 62.73 & -25.25 & -6.73 & 18.99 \\
\hline 67 & Y68 C5 & Space B, phase I & weak & $X$ & & CNA1355 & $9185 \pm 40$ & 63.25 & -25.68 & -6.72 & 19.45 \\
\hline 70 & Y68 E5 & Space B, phase I & weak & & $X$ & CNA1355 & $9185 \pm 40$ & 63.11 & -25.96 & -6.72 & 19.75 \\
\hline 72 & Y68 D5 & Space B, phase I & weak & $X$ & & CNA1355 & $9185 \pm 40$ & 63.09 & -24.66 & -6.72 & 18.39 \\
\hline 74 & X68 E1 & Space B, phase I & - & & $\mathrm{X}$ & CNA1355 & $9185 \pm 40$ & 63.95 & -25.88 & -6.72 & 19.67 \\
\hline 78 & X69 A1 & Space B, phase I & - & $X$ & & CNA1355 & $9185 \pm 40$ & 59.09 & -26.25 & -6.72 & 20.05 \\
\hline 80 & X68 D1 & Space B, phase I & moderate & & $X$ & CNA1355 & $9185 \pm 40$ & 61.63 & -24.61 & -6.72 & 18.34 \\
\hline 88 & Y68 B4 & Space B, phase I & weak & $\mathrm{X}$ & & CNA1355 & $9185 \pm 40$ & 59.81 & -24.86 & -6.72 & 18.60 \\
\hline 85 & $\begin{array}{l}\text { Y68 } \\
\text { B4/5 }\end{array}$ & $\begin{array}{l}\text { Space B, phase III } \\
\text { (pit) }\end{array}$ & - & $X$ & & CNA1354 & $9292 \pm 48$ & 64.36 & -25.18 & -6.73 & 18.92 \\
\hline 11245 & BB29 & $\begin{array}{l}\text { Space A, phase II, } \\
\text { roof }\end{array}$ & - & & $X$ & CNA1065 & $9300 \pm 50$ & 54.65 & -23.55 & -6.73 & 17.23 \\
\hline 11244 & BB28 & $\begin{array}{l}\text { Space A, phase II, } \\
\text { roof }\end{array}$ & strong & & $X$ & CNA1065 & $9300 \pm 50$ & 63.54 & -23.61 & -6.73 & 17.28 \\
\hline 11212 & BB10 & $\begin{array}{l}\text { Space A, phase II, } \\
\text { roof }\end{array}$ & moderate & & $X$ & CNA1065 & $9300 \pm 50$ & 60.57 & -23.55 & -6.73 & 17.22 \\
\hline 11246 & BB30 & $\begin{array}{l}\text { Space A, phase II, } \\
\text { roof }\end{array}$ & - & $X$ & & CNA1065 & $9300 \pm 50$ & 56.08 & -24.25 & -6.73 & 17.95 \\
\hline 11238 & BB24 & $\begin{array}{l}\text { Space A, phase II, } \\
\text { roof }\end{array}$ & - & $X$ & & CNA1065 & $9300 \pm 50$ & 60.97 & -23.93 & -6.73 & 17.62 \\
\hline 11247 & BB31 & $\begin{array}{l}\text { Space A, phase II, } \\
\text { roof }\end{array}$ & - & $X$ & & CNA1065 & $9300 \pm 50$ & 60.17 & -24.98 & -6.73 & 18.71 \\
\hline
\end{tabular}




\begin{tabular}{|c|c|c|c|c|c|c|c|c|c|c|c|}
\hline $\begin{array}{l}\text { Sample } \\
\mathbf{N}^{\mathbf{0}} \\
\end{array}$ & $\begin{array}{l}\text { Sample } \\
\text { ID } \\
\end{array}$ & Layer & $\begin{array}{l}\text { Growth-ring } \\
\text { Curvature }\end{array}$ & $\begin{array}{l}\text { Pistacia } \\
\text { sp. }\end{array}$ & $\begin{array}{c}\text { Amygdalus } \\
\text { sp. }\end{array}$ & Reference & Data BP & $\% \mathrm{C}$ & $\begin{array}{c}\delta^{13} C_{\text {sample }} \\
(\%)\end{array}$ & $\begin{array}{c}\delta^{13} C_{\text {air }} \\
(\%)\end{array}$ & $\begin{array}{r}\Delta^{13} \mathrm{C} \\
(\%)\end{array}$ \\
\hline 11248 & BB32 & $\begin{array}{l}\text { Space A, phase II, } \\
\text { roof }\end{array}$ & weak & $X$ & & CNA1065 & $9300 \pm 50$ & 59.22 & -25.13 & -6.73 & 18.87 \\
\hline 11254 & BB36 & $\begin{array}{l}\text { Space A, phase II, } \\
\text { roof }\end{array}$ & moderate & $X$ & & CNA1065 & $9300 \pm 50$ & 59.74 & -23.61 & -6.73 & 17.28 \\
\hline 11266 & BB43 & $\begin{array}{l}\text { Space A, phase II, } \\
\text { roof }\end{array}$ & moderate & $X$ & & CNA1065 & $9300 \pm 50$ & 61.04 & -25.37 & -6.73 & 19.12 \\
\hline 11274 & BB48 & $\begin{array}{l}\text { Space A, phase II, } \\
\text { roof }\end{array}$ & moderate & $X$ & & CNA1065 & $9300 \pm 50$ & 62.75 & -25.16 & -6.73 & 18.90 \\
\hline $11232 / 3$ & BB22 & $\begin{array}{l}\text { Space A, phase II, } \\
\text { roof }\end{array}$ & moderate & $X$ & & CNA1065 & $9300 \pm 50$ & 60.16 & -24.79 & -6.73 & 18.51 \\
\hline 11218 & BB12 & $\begin{array}{l}\text { Space A, phase II, } \\
\text { roof }\end{array}$ & moderate & $X$ & & CNA1065 & $9300 \pm 50$ & 61.50 & -23.48 & -6.73 & 17.14 \\
\hline 11242 & BB27 & $\begin{array}{l}\text { Space A, phase II, } \\
\text { roof }\end{array}$ & weak & $X$ & & CNA1065 & $9300 \pm 50$ & 59.02 & -23.86 & -6.73 & 17.55 \\
\hline 11249 & BB33 & $\begin{array}{l}\text { Space A, phase II, } \\
\text { roof }\end{array}$ & weak & $X$ & & CNA1065 & $9300 \pm 50$ & 62.76 & -25.27 & -6.73 & 19.02 \\
\hline 11263 & BB40 & $\begin{array}{l}\text { Space A, phase II, } \\
\text { roof }\end{array}$ & weak & $X$ & & CNA1065 & $9300 \pm 50$ & 57.47 & -23.65 & -6.73 & 17.32 \\
\hline 11267 & BB44 & $\begin{array}{l}\text { Space A, phase II, } \\
\text { roof }\end{array}$ & strong & $X$ & & CNA1065 & $9300 \pm 50$ & 63.78 & -23.22 & -6.73 & 16.87 \\
\hline 11250 & BB34 & $\begin{array}{l}\text { Space A, phase II, } \\
\text { roof }\end{array}$ & weak & $X$ & & CNA1065 & $9300 \pm 50$ & 57.71 & -24.12 & -6.73 & 17.82 \\
\hline 11221 & BB15 & $\begin{array}{l}\text { Space A, phase II, } \\
\text { roof }\end{array}$ & weak & $X$ & & CNA1065 & $9300 \pm 50$ & 60.63 & -24.46 & -6.73 & 18.17 \\
\hline 11253 & BB35 & $\begin{array}{l}\text { Space A, phase II, } \\
\text { roof }\end{array}$ & weak & $X$ & & CNA1065 & $9300 \pm 50$ & 64.27 & -24.06 & -6.73 & 17.75 \\
\hline
\end{tabular}




\begin{tabular}{|c|c|c|c|c|c|c|c|c|c|c|c|}
\hline $\begin{array}{l}\text { Sample } \\
\mathbf{N}^{\mathbf{0}} \\
\end{array}$ & $\begin{array}{l}\text { Sample } \\
\text { ID }\end{array}$ & Layer & $\begin{array}{l}\text { Growth- } \\
\text { ring } \\
\text { Curvature }\end{array}$ & $\begin{array}{c}\text { Pistacia } \\
\text { sp. }\end{array}$ & $\begin{array}{c}\text { Amygdalus } \\
\text { sp. }\end{array}$ & Reference & Data BP & $\% \mathrm{C}$ & $\begin{array}{c}\delta^{13} C_{\text {sample }} \\
\text { (\%o) }\end{array}$ & $\begin{array}{c}\delta^{13} \mathrm{C}_{\text {air }} \\
(\%)\end{array}$ & $\begin{array}{l}\Delta^{13} \mathrm{C} \\
(\%)\end{array}$ \\
\hline 11228 & BB18 & $\begin{array}{c}\text { Space A, phase II, } \\
\text { roof }\end{array}$ & weak & $X$ & & CNA1065 & $9300 \pm 50$ & 63.45 & -23.31 & -6.73 & 16.97 \\
\hline 11234 & BB23 & $\begin{array}{c}\text { Space A, phase II, } \\
\text { roof }\end{array}$ & weak & $X$ & & CNA1065 & $9300 \pm 50$ & 60.88 & -24.35 & -6.73 & 18.05 \\
\hline 11193 & BB4 & $\begin{array}{c}\text { Space A, phase II, } \\
\text { roof }\end{array}$ & weak & $X$ & & CNA1065 & $9300 \pm 50$ & 64.34 & -24.08 & -6.73 & 17.77 \\
\hline 11277 & BB51 & $\begin{array}{l}\text { Space A, phase II, } \\
\text { roof }\end{array}$ & weak & $X$ & & CNA1065 & $9300 \pm 50$ & 56.46 & -24.00 & -6.73 & 17.69 \\
\hline 11265 & BB42 & $\begin{array}{l}\text { Space A, phase II, } \\
\text { roof }\end{array}$ & weak & $X$ & & CNA1065 & $9300 \pm 50$ & 61.24 & -23.01 & -6.73 & 16.65 \\
\hline 11279 & BB53 & $\begin{array}{c}\text { Space A, phase II, } \\
\text { roof }\end{array}$ & weak & $X$ & & CNA1065 & $9300 \pm 50$ & 57.18 & -23.86 & -6.73 & 17.55 \\
\hline 11260 & BB39 & $\begin{array}{c}\text { Space A, phase II, } \\
\text { roof }\end{array}$ & weak & $X$ & & CNA1065 & $9300 \pm 50$ & 57.41 & -24.42 & -6.73 & 18.12 \\
\hline 11214 & BB11 & $\begin{array}{l}\text { Space A, phase II, } \\
\text { roof }\end{array}$ & weak & $X$ & & CNA1065 & $9300 \pm 50$ & 61.20 & -24.22 & -6.73 & 17.92 \\
\hline 11278 & BB52 & $\begin{array}{l}\text { Space A, phase II, } \\
\text { roof }\end{array}$ & weak & $X$ & & CNA1065 & $9300 \pm 50$ & 58.98 & -23.55 & -6.73 & 17.22 \\
\hline 11256 & BB38 & $\begin{array}{l}\text { Space A, phase II, } \\
\text { roof }\end{array}$ & weak & $X$ & & CNA1065 & $9300 \pm 50$ & 61.93 & -25.02 & -6.73 & 18.76 \\
\hline 11273 & BB47 & $\begin{array}{c}\text { Space A, phase II, } \\
\text { roof }\end{array}$ & weak & $X$ & & CNA1065 & $9300 \pm 50$ & 57.67 & -23.97 & -6.73 & 17.65 \\
\hline \multirow[t]{3}{*}{11275} & BB49 & $\begin{array}{l}\text { Space A, phase II, } \\
\text { roof }\end{array}$ & weak & $X$ & & CNA1065 & $9300 \pm 50$ & 56.97 & -24.22 & -6.73 & 17.92 \\
\hline & BB54 & $\begin{array}{l}\text { Space A, phase II, } \\
\text { roof }\end{array}$ & strong & $X$ & & CNA1065 & $9300 \pm 50$ & 56.30 & -24.79 & -6.73 & 18.52 \\
\hline & BB55 & $\begin{array}{l}\text { Space A, phase II, } \\
\text { roof }\end{array}$ & moderate & $X$ & & CNA1065 & $9300 \pm 50$ & 57.32 & -23.64 & -6.73 & 17.32 \\
\hline
\end{tabular}


Table S3. Carbon isotope discrimination $\left(\Delta^{13} \mathrm{C}, \%\right.$ o $)$ of the charcoal remains recovered in different phases of the Space A (area XYZ) and classified attending their degree of growth-ring curvature. Values presented are means \pm SD. Comparisons were performed only for those phases where charcoals from the same genus and different curvatures were recovered as detailed in Table S2. Samples from phases II (Roof) and IV belong to Pistacia sp., whereas samples from phases V and VI are of Amygdalus sp. Differences across categories of charcoals were tested with ANOVA.

$\begin{array}{llll}\text { Growth-ring } & \text { Phase II (Roof) Phase IV Phase V VI }\end{array}$

\section{Curvature}

\begin{tabular}{|c|c|c|}
\hline Weak & $17.74 \pm 0.60$ & $18.61 \pm 0.24$ \\
\hline
\end{tabular}

$\begin{array}{lllll}\text { Moderate } & 18.05 \pm 0.91 & / & / & 19.54 \pm 0.27\end{array}$

$\begin{array}{llll}\text { Strong } & 17.69 \pm 1.16 & 17.93 \pm 1.25 & 19.07 \pm 0.50\end{array}$

$\begin{array}{lllll}\text { Level of significance } \quad 0.654^{\mathrm{ns}} & 0.395^{\mathrm{ns}} & 0.252^{\mathrm{ns}} & 0.086^{\mathrm{ns}}\end{array}$


Table S4. Provenance, description of samples and main phytolith results obtained from excavation areas XYZ and VU at Tell Qarassa North.

\begin{tabular}{|c|c|c|c|c|c|c|}
\hline$\overline{\text { Area }}$ & $\begin{array}{l}\text { Sample } \\
\text { number }\end{array}$ & Phase & $\begin{array}{l}\text { Phytoliths } 1 \mathrm{~g} \text { of } \\
\text { sediment } \\
\text { (million) }\end{array}$ & $\begin{array}{l}\text { Phytoliths } \\
\text { weathering } \\
(\%)\end{array}$ & $\begin{array}{l}\text { Multicelled } \\
\text { phytoliths } \\
(\%)\end{array}$ & Description \\
\hline \multirow[t]{6}{*}{$\begin{array}{l}\text { XYZ- } \\
67 / 68 / 69\end{array}$} & 8 & $\mathrm{~V}$ & 1.19 & 5.6 & 2.3 & $\begin{array}{l}\text { Dark very fine ashy powdery clayey silt without clasts, } \\
\text { including flint, bone and pottery. }\end{array}$ \\
\hline & 12 & IV & 1.3 & 6.2 & 1.6 & $\begin{array}{l}\text { Dark very fine ashy powdery clayey silt. The matrix is } \\
\text { similar to unit } 3 \text {, with few scattered small rounded basalt } \\
\text { clasts and randomly scattered larger stones. The dominant } \\
\text { colour is dark greyish brown. }\end{array}$ \\
\hline & 16 & IV & 1.3 & 3.9 & 6.6 & $\begin{array}{l}\text { Dark very fine ashy powdery clayey silt, small rounded basalt } \\
\text { clasts and abundance of randomly scattered larger stones. }\end{array}$ \\
\hline & $\begin{array}{l}\text { Base } \\
2009,1\end{array}$ & III & 2 & 5.4 & 10.9 & $\begin{array}{l}\text { Almost exclusively reddish yellow adobe compounds, } \\
\text { embedded in a fine matrix of similar colour. }\end{array}$ \\
\hline & $\begin{array}{l}\text { Base } \\
2009 \\
\text { out }\end{array}$ & III & 1.3 & 7.5 & 0.9 & Reddish yellow adobe compounds. \\
\hline & 29 & II & 2.6 & 1.2 & 42.3 & $\begin{array}{l}\text { Ashy with large fragments of charcoal, including carbonized } \\
\text { wooden elements, heavily burned adobe and non-wooden } \\
\text { plant remains. }\end{array}$ \\
\hline
\end{tabular}


Massive homogeneous pulverised reddish yellow adobe including decimetric angular basalt clasts and small basalt clasts.

\begin{tabular}{|c|c|c|c|c|c|c|}
\hline \multirow[t]{11}{*}{ VU-67 } & 1 & & 1.7 & 5.2 & 2.4 & Compact clay sediment. \\
\hline & 3 & & 1.2 & 9.6 & 2 & Clayey silt with small basalt clasts, greyish brown colour. \\
\hline & 5 & $\mathrm{~V}$ & 0.84 & 7.1 & 0.9 & Powdery clayey silt, brown colour. \\
\hline & 8 & $\mathrm{~V}$ & 1.4 & 5.1 & 4.1 & Powdery clayey silt, similar to US 3 but darker. \\
\hline & 10 & $\mathrm{~V}$ & 0.72 & 7.2 & 0 & Powdery clayey silt, similar to US 3 but darker. \\
\hline & 11 & $\mathrm{~V}$ & 1.3 & 9.1 & 7.3 & Dark gray ashy sediments, including adobe compounds. \\
\hline & 12 & IV & 0.88 & 8.6 & 9.1 & $\begin{array}{l}\text { Yellowish brown sediments, including adobe fragments, } \\
\text { ashes, charcoal, bone and lithic artefacts. }\end{array}$ \\
\hline & 18 & IV & 0.97 & 7.9 & 3 & $\begin{array}{l}\text { Yellowish brown sediments, including adobe fragments, } \\
\text { ashes, charcoal, bone and lithic artefacts. }\end{array}$ \\
\hline & EF18-1 & IV & 1.1 & 7.9 & 1.8 & Burial EF18, close to cranial remains. \\
\hline & EF18-2 & IV & 0.74 & 6.7 & 1.2 & Burial EF18, under the pit base. \\
\hline & 21 & IV & 0.95 & 6.6 & 2.4 & $\begin{array}{l}\text { Clayey matrix sediments and basalt clasts, with abundant } \\
\text { ashes charcoal fragments, bone and lithic artifacts. }\end{array}$ \\
\hline
\end{tabular}


Table S5. Summary of the early Holocene wood charcoal records in southwest Asia. Numbers represent percentage fragment counts by taxa. In some cases the raw datasets were not available, and the presence of taxa was recorded with an X. "Small shrubs" comprise steppic taxa such as Artemisia, Acacia, Atriplex, Paliurus etc. "Others" represent rare taxa (e.g., Vitis, Leguminosae), as well as cf. identifications of taxa not included in the table (e.g. cf. Labiatae). Quercus (E, D) means Quercus evergreen and deciduous respectively. Total fragments were calculated excluding indeterminate wood charcoal fragments.

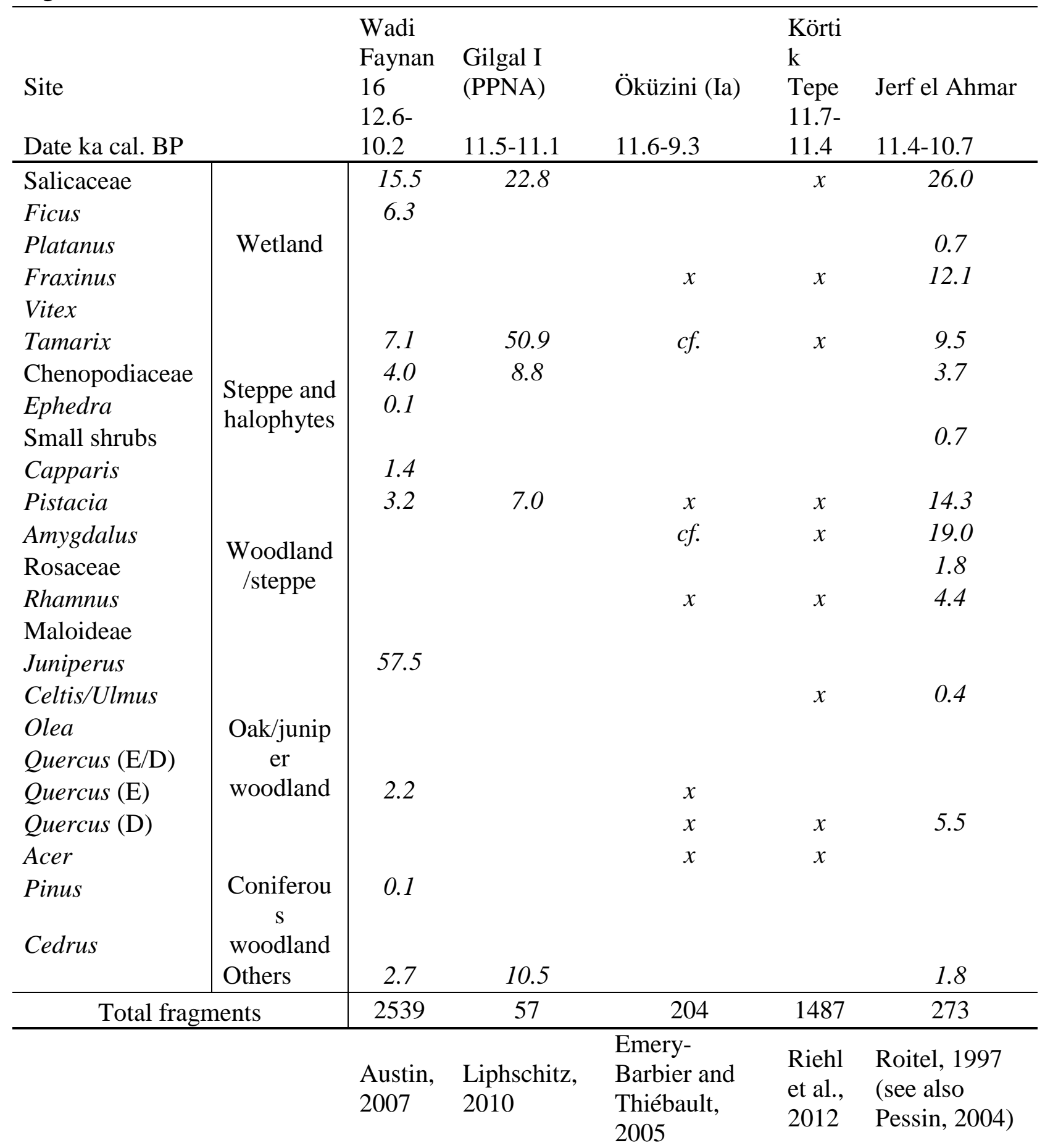




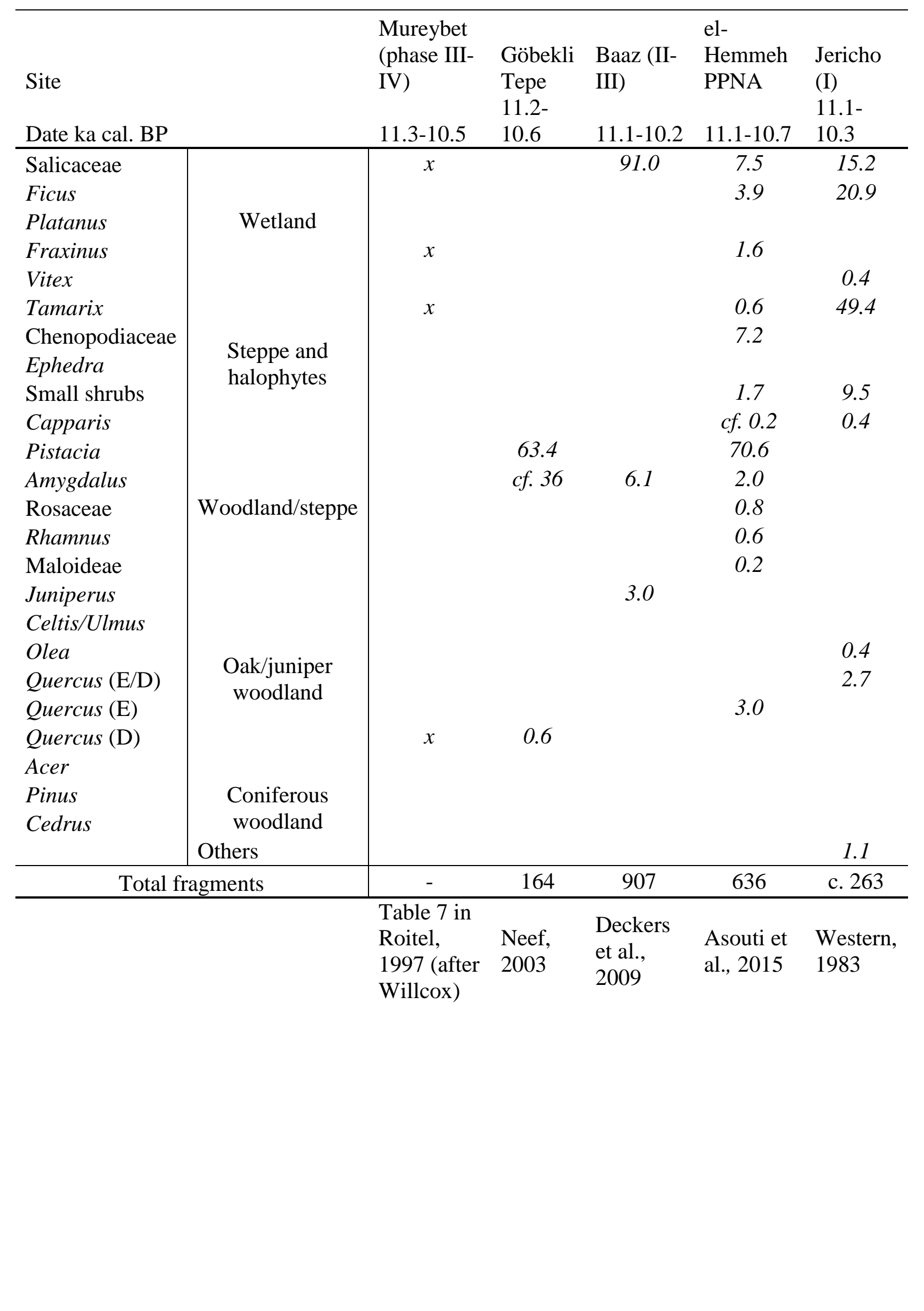




\begin{tabular}{|c|c|c|c|c|c|c|}
\hline $\begin{array}{l}\text { Site } \\
\text { Date ka cal. BP }\end{array}$ & & $\begin{array}{l}\text { Chogha } \\
\text { Golan } \\
\text { (XI-VII) }\end{array}$ & $\begin{array}{l}\text { Pinarba } \\
\text { şi (A) } \\
10.7- \\
10.5\end{array}$ & $\begin{array}{l}\text { Dja'de } \\
10.7-10.3\end{array}$ & $\begin{array}{l}\text { Horvat } \\
\text { Galil } \\
10.7-9.9\end{array}$ & $\begin{array}{l}\text { Mureybet } \\
\text { (phase IV) } \\
10.7- \\
9.9\end{array}$ \\
\hline $\begin{array}{l}\text { Salicaceae } \\
\text { Ficus } \\
\text { Platanus } \\
\text { Fraxinus } \\
\text { Vitex } \\
\text { Tamarix } \\
\text { Chenopodiaceae } \\
\text { Ephedra } \\
\text { Small shrubs } \\
\text { Capparis } \\
\text { Pistacia } \\
\text { Amygdalus } \\
\text { Rosaceae } \\
\text { Rhamnus } \\
\text { Maloideae } \\
\text { Juniperus } \\
\text { Celtis/Ulmus } \\
\text { Olea } \\
\text { Quercus (E/D) } \\
\text { Quercus (E) } \\
\text { Quercus (D) } \\
\text { Acer } \\
\text { Pinus } \\
\text { Cedrus }\end{array}$ & $\begin{array}{l}\text { Oak/juniper } \\
\text { woodland } \\
\text { Coniferous } \\
\text { woodland } \\
\text { Others }\end{array}$ & $\begin{array}{c}0.3 \\
23.5 \\
2.0 \\
0.3\end{array}$ & $\begin{array}{c}1.6 \\
4.9 \\
\\
1.6 \\
32.8 \\
55.7\end{array}$ & $\begin{array}{c}37.3 \\
\\
2.0 \\
9.7 \\
33.3 \\
4.6 \\
\\
0.7\end{array}$ & $\begin{array}{l}16.7 \\
16.7\end{array}$ & $x$ \\
\hline \multicolumn{2}{|c|}{ Total fragments } & 391 & 61 & 1116 & 6 & - \\
\hline & & $\begin{array}{l}\text { Riehl et } \\
\text { al., } 2015\end{array}$ & $\begin{array}{l}\text { Asouti, } \\
2003\end{array}$ & $\begin{array}{l}\text { Roitel, } \\
1997\end{array}$ & $\begin{array}{l}\text { Liphschitz, } \\
1997\end{array}$ & $\begin{array}{l}\text { Table } 7 \text { in } \\
\text { Roitel 1997, } \\
\text { after Willcox }\end{array}$ \\
\hline
\end{tabular}

7 


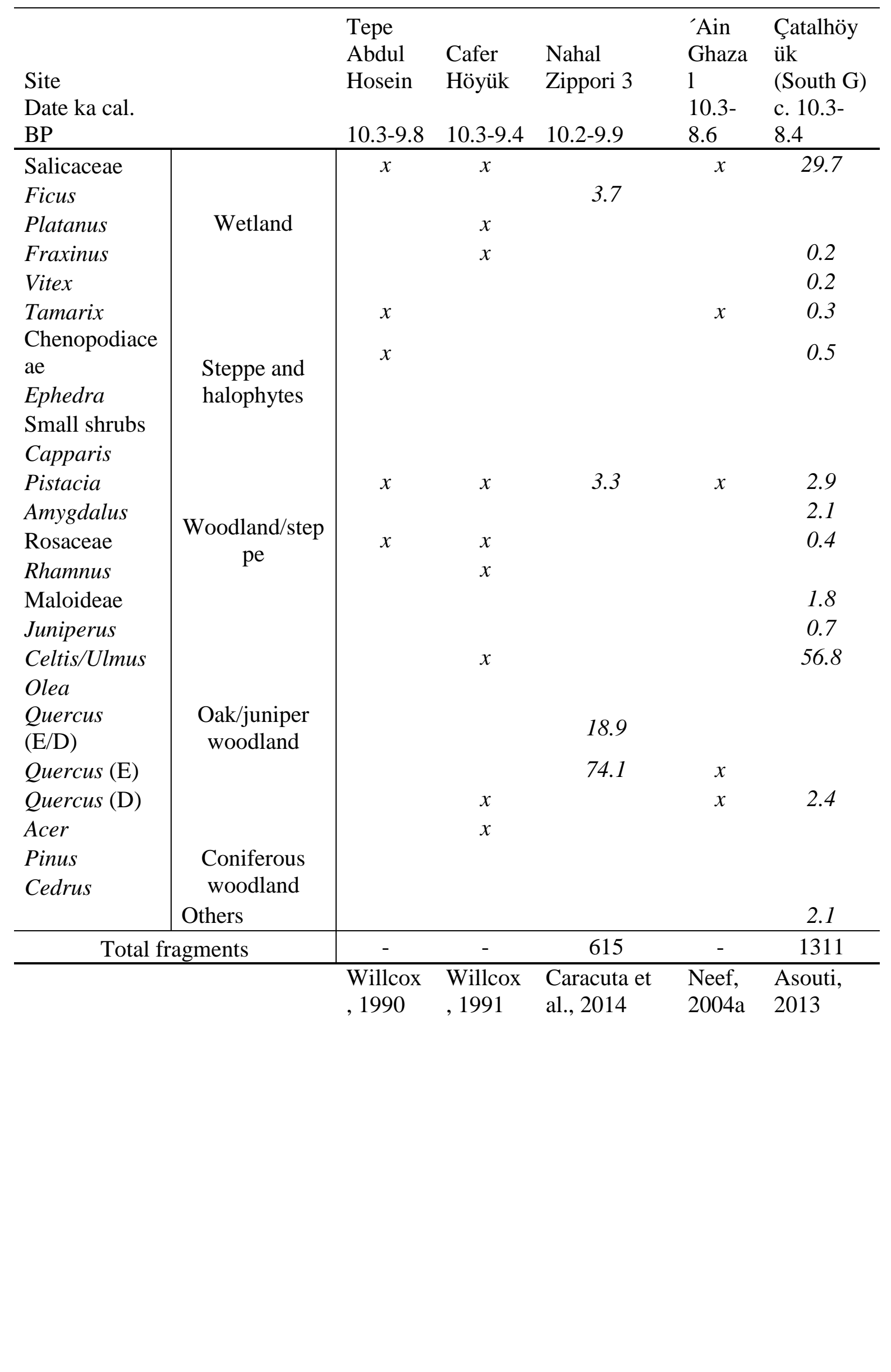




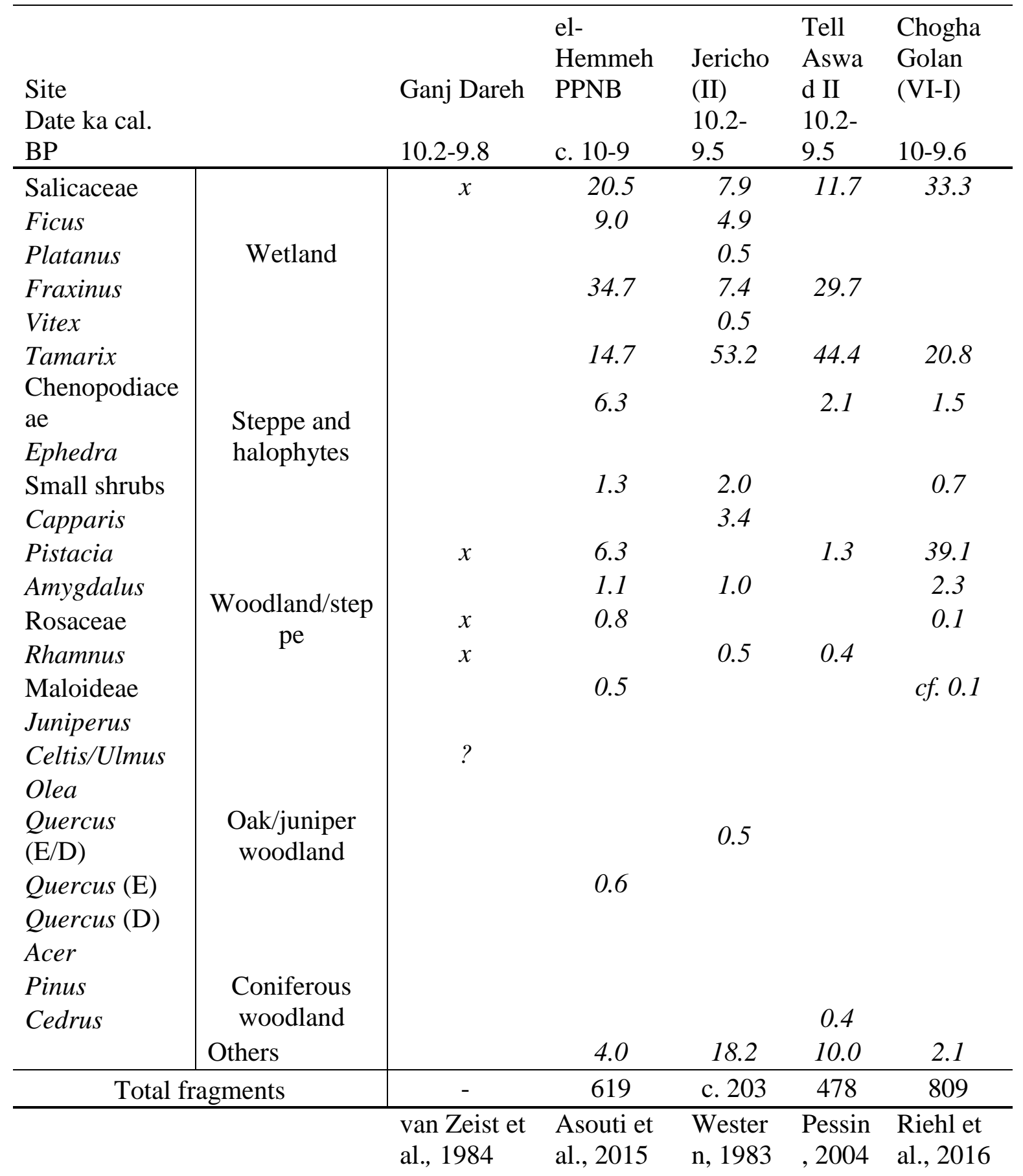




\begin{tabular}{|c|c|c|c|c|}
\hline $\begin{array}{l}\text { Site } \\
\text { Date ka cal. BP }\end{array}$ & & $\begin{array}{l}\text { Can Hassan } \\
\text { III } \\
9.7-9.4\end{array}$ & $\begin{array}{l}\text { Tell } \\
\text { Halula } \\
\text { (M/L } \\
\text { PPNB) } \\
9.8-9.3\end{array}$ & $\begin{array}{l}\text { Basta } \\
9.5-9.0\end{array}$ \\
\hline $\begin{array}{l}\text { Salicaceae } \\
\text { Ficus } \\
\text { Platanus } \\
\text { Fraxinus } \\
\text { Vitex } \\
\text { Tamarix } \\
\text { Chenopodiaceae } \\
\text { Ephedra } \\
\text { Small shrubs } \\
\text { Capparis } \\
\text { Pistacia } \\
\text { Amygdalus } \\
\text { Rosaceae } \\
\text { Rhamnus } \\
\text { Maloideae } \\
\text { Juniperus } \\
\text { Celtis/Ulmus } \\
\text { Olea } \\
\text { Quercus (E/D) } \\
\text { Quercus (E) } \\
\text { Quercus (D) } \\
\text { Acer } \\
\text { Pinus } \\
\text { Cedrus }\end{array}$ & $\begin{array}{c}\text { Wetland } \\
\text { Steppe and } \\
\text { halophytes } \\
\text { Woodland/steppe } \\
\\
\text { Oak/juniper } \\
\text { woodland } \\
\text { Coniferous } \\
\text { woodland } \\
\text { Others }\end{array}$ & $\begin{array}{l}x \\
x\end{array}$ & $\begin{array}{c}23.9 \\
1.2 \\
14.2 \\
30.6 \\
2.6 \\
\\
0.7 \\
11.0 \\
1.9 \\
0.2\end{array}$ & $x$ \\
\hline \multicolumn{2}{|c|}{ Total fragments } & \begin{tabular}{l}
\multicolumn{1}{c}{-} \\
Willcox, \\
1991, \\
Figure 2, p. \\
142
\end{tabular} & $\begin{array}{l}2322 \\
\begin{array}{l}\text { Roitel, } \\
1997\end{array}\end{array}$ & $\begin{array}{l}- \\
\text { Neef, } \\
2004 b\end{array}$ \\
\hline
\end{tabular}


41 Table S6. Faunal remains from excavations areas XYZ at Tell Qarassa North (NISP:

42 number of identified specimens). Bone tools were excluded from the counts.

\begin{tabular}{|c|c|c|c|c|c|c|c|c|c|c|}
\hline Taxa & Ares & $\overline{X Y 2}$ & III & IV & $\mathbf{V}$ & VI & $\begin{array}{l}\text { Area V } \\
\text { Lowe } \\
\text { r }\end{array}$ & $\begin{array}{l}\text { Uppe } \\
\mathbf{r}\end{array}$ & $\begin{array}{l}\text { Surf } \\
\text { ace } \\
\text { laye } \\
\text { rs }\end{array}$ & Total \\
\hline Vulpes sp. & 5 & 11 & 38 & 18 & 12 & 3 & 26 & 1 & 2 & 62 \\
\hline Meles meles & & & 6 & 1 & 3 & & & & & 4 \\
\hline Felis silvestris & & 2 & 5 & & 1 & & 3 & & & 4 \\
\hline Canis familiaris & & & 8 & 1 & 2 & 1 & & & & 4 \\
\hline $\begin{array}{l}\text { Carnivore } \\
\text { unidentified }\end{array}$ & 5 & 2 & 27 & 6 & 11 & & 13 & 1 & 2 & 33 \\
\hline Sus f. scrofa & & & 5 & 1 & 1 & 1 & 13 & & 2 & 18 \\
\hline Dama mesopotamica & & & 1 & 1 & 2 & & & & 1 & 4 \\
\hline Bos f. primigenius & 2 & 2 & 22 & 16 & 7 & 24 & 5 & 8 & 2 & 62 \\
\hline Large ungulate & 1 & 1 & 1 & 16 & 37 & 7 & 3 & 5 & 9 & 77 \\
\hline Gazella ssp. & 15 & 8 & 89 & 38 & 61 & 23 & 67 & 21 & 12 & 222 \\
\hline Capra f. aegagrus & 15 & 1 & 7 & 27 & 49 & 1 & 38 & 12 & 2 & 129 \\
\hline Capra/Ovis & 18 & 15 & 15 & 46 & 74 & 18 & 59 & 9 & 14 & 220 \\
\hline Small ungulate & 3 & 34 & 232 & 75 & 181 & 21 & 14 & 16 & 18 & 325 \\
\hline Lepus capensis & 2 & 3 & 25 & 6 & 12 & 2 & 8 & 4 & & 32 \\
\hline Erinaceus concolor & & & 1 & & & & & & & 0 \\
\hline Anas acuta & 1 & & & & & & & & & 0 \\
\hline Anas platyrhynchos & 1 & & 3 & & 5 & 1 & & 1 & 2 & 9 \\
\hline Anas crecca & & & 1 & & 1 & & & & & 1 \\
\hline $\begin{array}{l}\text { A. } \\
\text { crecca/querquedula }\end{array}$ & & & & & 1 & & & 1 & & 2 \\
\hline Anatinae unidentified & & & 4 & & 2 & & 1 & & & 3 \\
\hline Aquila f. chrysaetos & & & & & & & 1 & & & 1 \\
\hline Accipitridae & & 1 & & & & & & & & 0 \\
\hline Alectoris chukar & & 1 & 11 & 1 & 3 & 1 & 5 & & & 10 \\
\hline Rallidae & & & 1 & & & & & & & 0 \\
\hline Otis tarda & & & & 1 & & & & & & 1 \\
\hline Corvus corone & & & 1 & & 1 & & & & & 1 \\
\hline Birds unidentified & 2 & 1 & 9 & 5 & 4 & & 4 & & & 13 \\
\hline Total NISP & 101 & 94 & 706 & 264 & 558 & 113 & 409 & 82 & 102 & 1528 \\
\hline
\end{tabular}


Figure S1. Summary of early Holocene pollen (black circles) and wood charcoal (black squares) records (based on Table S5, excluding riparian taxa) in relationship to modernday phytogeographical regions in southwest Asia (schematic representation based on vegetation maps by Frey and Kürschner, 1989). Dark orange: Irano-Turanian arid steppe; Grey: Irano-Turanian deciduous steppe and open parkland. Light orange: Saharo-Arabian semi-desert vegetation. Yellow: Sudanian desert. Light green: Mediterranean maquis; Turquoise: Mediterranean evergreen and deciduous oak forests; Dark green: coniferous forests. 1. Basta; 2. Wadi Faynan 16; 3. El-Hemmeh; 4. Jericho; 5. Gilgal I; 6. Ain Ghazal; 7. Nahal Zippori 3; 8. Horvat Galil; 9. Tell Qarassa North; 10. Tell Aswad: 11. Baaz Rockshelter; 12. Mureybet; 13. Dja'de; 14. Jerf el Ahmar; 15. Tell Halula; 16. Göbekli Tepe; 17. Körtik Tepe; 18. Cafer Höyük; 19. Can Hassan III; 20. Çatalhöyük; 21. Öküzini Cave; 22. Pinarbaşi; 23. Ganj Dareh; 24. Tepe Abdul Hosein; 25. Chogha Golan. I. Ein Gedi (Litt et al., 2012); II. Hula pollen core (van Zeist et al., 2009); III. Birkat Ram Crate (Schiebel, 2013): IV. Aamiq wetland (Hajar et al., 2008); V. Ghab (Wright and Thorpe, 2003); VI. Eski Acigöl (Roberts et al., 2001); VII. Akgöl (Bottema and Woldring, 1984); VIII. Lake Van (Wick et al., 2003); IX. Lake Urmia (Djamali et al., 2008b); X. Lake Zeribar (van Zeist and Bottema, 1977); XI. Lake Mirabad (van Zeist and Bottema, 1977).

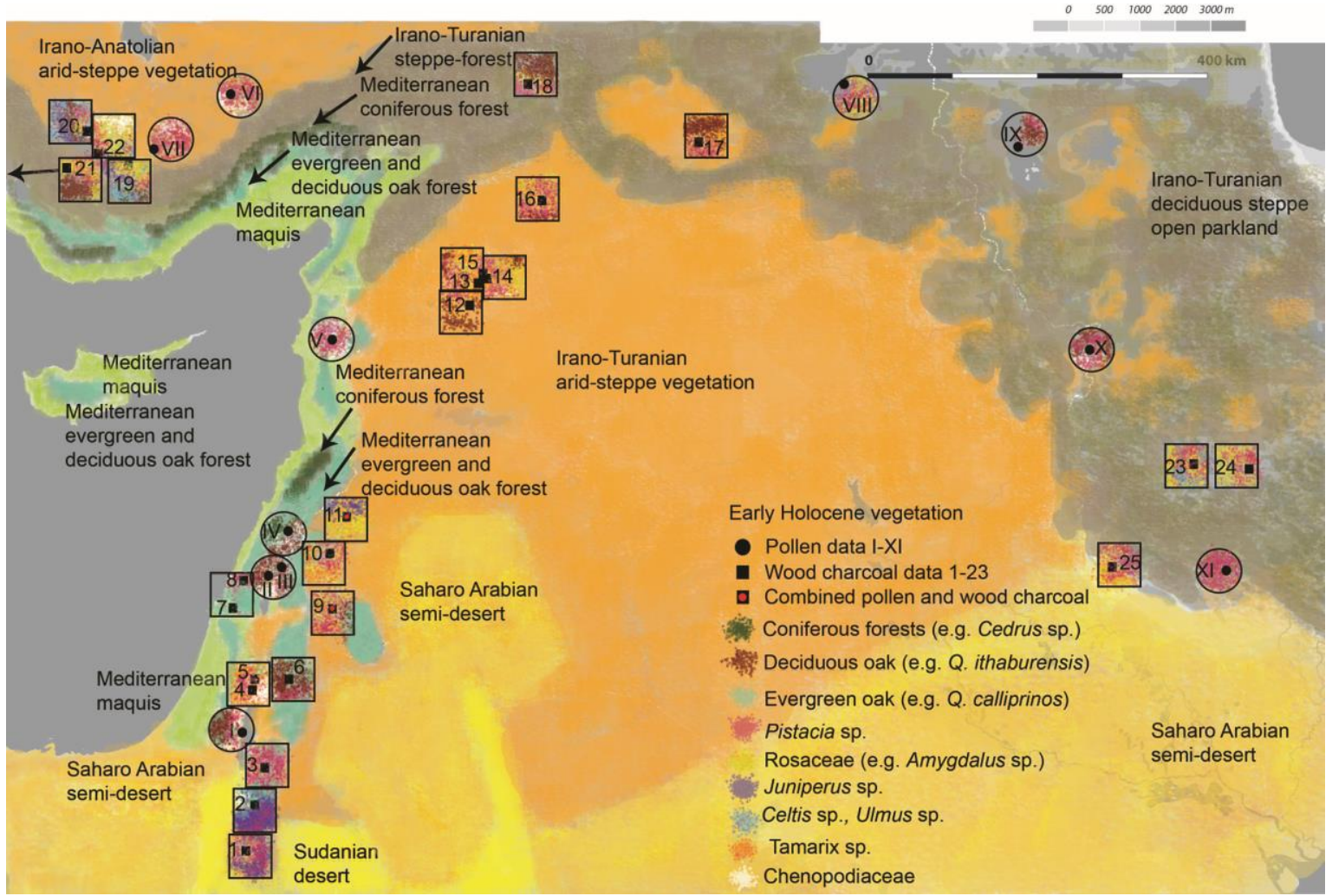




\section{References}

Aharonovich, S., Sharon, G., Weinstein-Evron, M., 2014. Palynological investigations at the middle palaeolithic site of Nahal Mahanayeem outlet, Israel. Quatern. Int. 33, 149-166.

Albert, R.M., Weiner, S. 2001. Study of phytoliths in prehistoric ash layers using a quantitative approach. In: Meunier J.D., Colin, F. (Eds.), Phytoliths, Applications in Earth Sciences and Human History, AA Balkema Publishers, 251-266.

Albert, R.M., Shahack-Gross, R., Cabanes, D., Gilboa, A., Lev-Yadun, S, Portillo, M., Sharon, I., Boaretto, E., Weiner, S. 2008. Phytolith-rich Layers from the Late Bronze and Iron Ages at Tel Dor (Israel): Mode of Formation and Archaeological Significance. $J$ Archaeol Sci 35, 57-75.

Albert, R.M., Esteve, X., Portillo, M., Rodríguez-Cintas, A., Cabanes, D., Esteban, I., Hernández, F. 2011. Phytolith CoRe, Phytolith Reference Collection. http://phytcore.org/phytolith/index. Accessed 21 November, 2015

Alley, R.B. 2000. The Younger Dryas cold interval as viewed from central Greenland. Quat Scie Rev 19, 213-226.

Araus, J.L., Ferrio, J.P., Voltas, J., Aguilera, M., Buxó R. 2014. Agronomic conditions and crop evolution in ancient Near East agriculture. Nature Commun., Article number: 3953. Doi:10.1038/ncomms4953.

Arranz-Otaegui, A. 2016. Evaluating the impact of water flotation and the state of the wood in archaeological wood charcoal remains: implications for the reconstruction of past vegetation and identification of firewood gathering strategies at Tell Qarassa North (South Syria). Quat Int, Doi:10.1016/j.quaint.2016.06.030

Arranz-Otaegui, A., Colledge, S., Ibañez, J.J., Zapata, L. 2016a. Crop husbandry activities and wild plant gathering, use and consumption at the EPPNB Tell Qarassa North (south Syria). Veg Hist Archaeobot, doi:10.1007/s00334-016-0564-0 
Arranz-Otaegui, A., Ibañez, J.J., Zapata, L. 2016b: Hunter-gatherer plant use in southwest Asia: the path to agriculture. In: Hardy, K., Kubiak-Martens, L. (Eds.), Wild Harvest: Plants in the Hominin and Pre-Agrarian Human Worlds, Oxbow Books, 91-110.

Arz, H.W., Lamy, F., Patzold, J., Müller, P.J., Prins, M., 2003. Mediterranean moisture source for an early-holocene humid period in the northern red sea. Science 300, 118. http://dx.doi.org/10.1126/science.1080325.

Asouti, E. 2003. Woodland vegetation and fuel exploitation at the prehistoric campsite of Pinarbaşi, south-central Anatolia, Turkey: the evidence from the wood charcoal macroremains. J Archaeol Sci 30(9), 1185-1201.

Asouti, E., Fuller, D.Q. 2012. From foraging to farming in the southern Levant: the development of Epipalaeolithic and Pre-Pottery Neolithic plant management strategies. Veg Hist Archaeobot 21, 149-162.

Asouti, E., Fuller, D.Q. 2013. A contextual approach to the emergence of agriculture in Southwest Asia. Reconstructing Early Neolithic plant-food production. Curr Anthropol 54(3), 299-345.

Asouti, E., Kabukcu, C. 2014. Holocene semi-arid oak-woodlands in the Irano-Anatolian region of Southwest Asia: natural or anthropogenic?. Quat Sci Rev 90, 158-182.

Asouti, E., Kabukcu, C., White, C. E., Kuijt, I., Finlayson, B., \& Makarewicz, C. 2015. Early Holocene woodland vegetation and human impacts in the arid zone of the southern Levant. The Holocene 25(10), 1565-1580.

Austin, P., 2007. The wood charcoal macroremains. In: Finlayson, B., Mithen, S. (Eds.), The Early Prehistory of Wadi Faynan, Southern Jordan (Levant Supplementary Series 4). Oxbow, Oxford, pp. 408-419.

Balbo A.L., Iriarte E., Arranz A., Zapata L., Lancelotti C., Madella, M., Teira, L., Jiménez, M., Braemer, F., Ibañez, J.J. 2012. Squaring the Circle. Social and Environmental 
Implications of Pre-Pottery Neolithic Building Technology at Tell Qarassa (South Syria). PLoS ONE 7(7): e42109. doi:10.1371/journal.pone.0042109

Bar-Matthews, M., Ayalon, A., Kaufman, A. 2000. Timing and hydrological conditions of Sapropel events in the Eastern Mediterranean, as evident from speleothems, Soreq cave, Israel. Chem Geol 169, 145-156.

Behre, K.E., 1981. The interpretation of anthropogenic indicators in pollen diagrams.

Pollen Spores 23, 225-245.

Bennett, K.D. 1996. Determination of the number of zones in a biostratigraphical sequence. New Phytol 132, 155-170.

Berger, J.F., Lespez, L., Kuzucuoglu, C., Glais, A., Hourani, F., Barra, A., Guilaine, J., 2016. Interactions between climate change and human activities during the early to midHolocene in the eastern Mediterranean basins. Clim. Past. 12, 1847-1877.

Berger, J.F., Guilaine, J., 2009. The 8200 cal BP abrupt environmental change and the Neolithic transition: a Mediterranean perspective. Quat. Int. 200, 31-49.

Beug, H.J., 2004. Leitfaden der Pollenbestimmung für Mitteleuropa und angrenzende Gebiete, Gustav Fisher Verlag.

Blumler, M.A., 2007. Near Eastern pollen diagrams and "deforestation". Middle States Geogr. 40, 150-157.

Bobek, H., 1963. Nature and Implications of Quaternary Climatic Changes in Iran. Changes of Climate. UNESCO, pp. 403-413.

Bond G, Showers W, Cheseby M, Lotti R, Almasi P, deMenocal P, et al. (1997) A pervasive millennialscale cycle in North Atlantic Holocene and glacial climates. Science 278(5341): 1257-1266.

Borrell, F., Junno, A., Barcelo, J.A., 2015. Synchronous environmental and cultural change in the emergence of agricultural economies 10,000 Years ago in the levant. PLoS One 10 (8), e0134810. http://dx.doi.org/10.1371/journal.pone.0134810. 
Bottema, S. 1975. The interpretation of pollen spectra from prehistoric settlements (with special attention to liguliflorae). Palaeohistoria 17, 17-35.

Bottema, S., 1977. A pollen diagram from the Syrian anti Lebanon. Paleorient 3, 259-268.

Bottema, S., 1986. A late quaternary pollen diagram from lake urmia (northwestern Iran). Rev. Palaeobot. Palynology 47, 241-261.

Bottema, S., Woldring, H. 1984. Late Quaternary vegetation and climate of southwestern Turkey, Part II. Palaeohistoria 26, 123-149.

Boyer, P., Roberts, N., Baird, D., 2006. Holocene environment and settlement on the Carsamba alluvial fan, south-central Turkey: integrating geoarchaeology and archaeological field survey. Geoarchaeology 21, 675-698.

Braemer, F., Nicolle, C., Steimer-Herbet, T., Broutin, P., Flambeaux, A., Abdo, K. 2007. Atlas archeologique des sites pre- et protohistoriques de Syrie du Sud. Étude préliminaire du site de Qarassa (Mohafazat de Suweida). Chron Archeola Syrie 3, 88-101.

Braemer, F., Genequand, D., Dumond Maridat, C., Blanc, P.M., Dentzer, J.-M., Gazagne, D., Wech, P. 2009. Long-term management of water in the Central Levant: the Hawran case (Syria). World Archaeol 41(1), 36-57.

Braemer, F., Ibanez, J.J., Shaarani, W., 2011. Qarassa (Mohafazat de Suweida): campagne 2009. Chron Archeol Syrie 5, 31-42.

Brown, D.A. 1984. Prospects and limits of a phytolith key for grasses in the central United States. J Archaeol Sci 11, 345-368.

Burjachs, F., López-Sáez, J.A., Iriarte, M.J. 2003. Metodología Arqueopalinológica. In: Buxó, R. and Piqué, R. (Eds.), La recogida de muestras en Arqueobotánica: objetivos y propuestas metodológicas. La gestión de los recursos vegetales y la transformación del paleopaisaje en el Mediterráneo occidental, Museu d'Arqueologia de Catalunya, 11-18. 
210 Chabal, L. 1989. Perspectives anthracologiques sur le site de Lattes (Hérault), Lattara, vol.

Cai, B., Edwards, R.L., Cheng, H., Tan, M.,Wang, X., Liu, T., 2008. A dry episode during the Younger Dryas and centennial-scale weak monsoon events during the early Holocene: a high-resolution stalagmite record from southeast of the Loess Plateau, China. Geophys. Res. Lett. 35 (2), L02705. http://dx.doi.org/10.1029/2007GL030986.

Caracuta, V., Weiss, E., van den Brink, E.C.M., Liran, R., Vardi, J., Barzilai, O., 2014.

From natural environment to human landscape: new archaeobotanical data from the neolithic site of nahal zippori 3, lower galilee. Neo-lithics 1/14, 33-41.

Chabal, L., 1989. Perspectives anthracologiques sur le site de Lattes (H erault). Lattara 2, 53-72.

Chabal, L. 1991. L'Homme et l'évolution de la végétation méditerranéenne, des âges des métaux à la période romaine: recherches anthracologiques théoriques, appliquées principalement à des sites du Bas-Languedoc. $\mathrm{PhD}$ thesis, Université de Montpellier II.

Chikahli, M., Amri, A. 2000. Jabal El- Arab: A Mediterranean Island. Dryland Agrobio 3, 8.

Davies, C.P., Fall, P.L., 2001. Modern pollen precipitation from an elevational transect in central Jordan and its relationship to vegetation. J. Biogeogr. 28, 1195-1210.

Deckers, K. 2016. Oak charcoal from northeastern Syria as proxy for vegetation, land use and climate in the second half of the Holocene. Rev Palaeobot Palynol 230, 22-36.

Deckers, K., Riehl, S., Jenkins, E., Rosen, A., Dodonov, A., Simakova, A.N., Conard, N.J., 2009. Vegetation development and human occupation in the Damascus region of southwestern Syria from the Late Pleistocene to Holocene. Veg. Hist. Archaeobot. 18, 329-340. 
DeNiro, M. J., Hastorf, C. A. 1985. Alteration of $15 \mathrm{~N} / 14 \mathrm{~N}$ and $13 \mathrm{C} / 12 \mathrm{C}$ ratios of plant matter during the initial stages of diagenesis: Studies utilizing archaeological specimens from Peru. Geochim Cosmochim Acta 49, 97-115.

Djamali, M., de Beaulieu, J.L., Miller, N.F., Andrieu-Ponel, V., Lak, R., Sadeddin, M., Akhani, H., Fazeli, H. 2008a. Vegetation history of the SE section of Zagros Mountains during the last five millennia; a pollen record from the Maharlou Lake, Fars Province, Iran. Veg Hist Archaeobot 18, 123-136.

Djamali, M., de Beaulieu, J.L., Shah-Hosseini, M., Andrieu-Ponel, V., Ponel, P., Amini, A., Akhani, H., Leroy, A.S., Stevens, L., Alizadeh, H., Brewer, S., 2008b. A late Pleistocene long pollen record from Lake Urmia, NW Iran. Quat. Res. 69, 413-420.

Devillers, B., 2005. Morphogenese et anthropisation holocenes d'un basin versant semiaride: le Gialias, Chypre. These de doctorat de geographie physique. Universite AixMarseille I.

El-Moslimany, A., 1983. History of Climate and Vegetation in the Eastern Mediterranean and Middle East from the Pleniglacial to the Mid-holocene. Ph.D. Dissertation. University of Washington.

El-Moslimany, A., 1986. Ecology and late-Quaternary history of the Kurdo-Zagrosian oak forest near Lake Zeribar, western Iran. Vegetation 68, 55-63.

Emery-Barbier, A., Thiebault, S., 2005. Preliminary conclusions on the Late Glacial vegetation in south-west Anatolia (Turkey): the complementary nature of palynological and anthracological approaches. J. Archaeol. Sci. 32, 1232-1251.

Ervynck, A., Dobney, K.M., Hongo, H., Meadow, R.H. 2001. Born Free ? New Evidence for the Status of Sus scrofa at Neolithic Çayönü Tepesi (Southeastern Anatolia, Turkey). Paléorient 27, 47-73.

Fahn, A., Werker, E., Baas, P. 1986. Wood anatomy and identification of trees and shrubs from Israel and adjacent regions, The Israel Academy of Sciences and Humanities. 
277 Falconer, S.E., Fall, P.L. 1995. Human impacts on the environment during the rise and collapse of civilization in the eastern Mediterranean. In: Steadman, D.W., Mead, J.I. (Eds.), Late Quaternary Environments and Deep History: A Tribute to Paul S. Martin. Hot Springs, South Dakota: The Mammoth Site of Hot Springs, Scientific Papers 3, 84101.

Fall, P.L., 2012. Modern vegetation, pollen and climate relationships on the Mediterranean island oc Cyprus. Rev. Palaeobot. Palynol. 185, 79-92.

Farquhar, G.D., Ehleringer, J.R., Hubick, K.T. 1989. Carbon isotope discrimination and photosynthesis. Ann Rev Plant Physiol Plant Mol Biol 40, 503-537.

Ferrio, J.P., Alonso, N., Voltas, J., Araus, J.L. 2004. Estimating grain weight in archaeological cereal crops: a quantitative approach for comparison with current conditions. J Archaeol Sci 31, 1635-1642.

292

Ferrio, J.P., Araus, J.L., Buxó, R., Voltas, J., Bort, J. 2005. Water management practices and climate in ancient agriculture: inference from the stable isotope composition of archaebotanical remains. Veget Hist Archaeobot 14, 510-517.

Fiorentino, G., Ferrio, J.P., Bogaard, A., Araus, J.L., Riehl, S. 2015. Stable isotopes in archaeological research. Veget Hist Archaeobot 24, 215-227.

Flohr, P., Fleitmann, D., Matthews, R., Matthews, W., Black, S., 2016. Evidence of resilience to past climate change in Southwest Asia: early farming communities and the 9.2 and 8.2 ka events. Quat. Sci. Rev. 136, 23-39.

Fotelli, M.N., Nahm, M., Radoglou, K., Rennenberg, H., Halyvopoulos, G., Matzarakis, A., 2009. Seasonal and interannual ecophysiological responses of beech (Fagus sylvatica) at its south-eastern distribution limit in Europe. For. Ecol. Manag. 257, 1157-1164. liqueur de Thoulet dans les sédiments minéraux. Pollen Spores 21, 239-251 
311 Grimm, E.C. 1987. Coniss: a Fortran 77 program for stratigraphically constrained cluster analysis by the method of incremental sum of squares. Comput Geosci 13, 13-35.

Grimm, E.D. 2004. TGView. Illinois State Museum, Research and Collection Center, Springfield.

Grigson, C. 1995. Plough and pasture in the early economy of the southern Levant. In:

Levy, T.E. (Ed.), The Archaeology of Society in the Holy Land, Leicester University Press, $245-268$.

Grove, A.T., Rackham, O., 2001. The Nature of Mediterranean Europe: an Ecological History. Yale University Press, London.

Hajar, L., Khater, C., Cheddadi, R., 2008. Vegetation changes during the late Pleistocene and Holocene in Lebanon: a pollen record from the Bekaa valley. Holocene 18 (7), 10891099.

Helmer, D., Gourichon, L., Monchot, H., Peters, J., Saña Seguí, M. 2005. Identifying early domestic cattle from Pre-Pottery Neolithic sites on the Middle Euphrates using sexual dimorphism. In: Vigne, J.-D., Peters, J., Helmer, D. (Eds.), The First Steps of Animal Domestication: New Archaeozological Approaches. Oxbow Books, Oxford, 86-95.

Helmer, D., Gourichon, L. 2008. Premières données sur les modalités de subsistance à Tell Aswad (Syrie, PPNB moyen et récent, Néolithique céramique ancien) - fouilles 20012005. In: Vila, E., Gourichon, L., Choyke, A.M., Buitenhuis, H. (Eds.), Archaeozoology of the Southwest Asia and Adjacent Areas VIII. Travaux de la Maison de l'Orient 49, Maison de l'Orient et de la Méditerranée, Lyon, 119-151.

Helmer, D., Gourichon, L. 2016. The fauna of Tell Aswad (Damascus, Syria), early 
Neolithic levels. Comparison with the northern and southern Levant sites. In: Mashkour, M., Beech, M. (Eds.), Archaeozoology of the Southwest Asia and Adjacent Areas IX. Oxbow Books, Oxford, 23-40.

Heun, M., Haldorsen, S., Vollan, K., 2008. Reassessing domestication events in the near east: einkorn and Triticum urartu. Genome 51, 444-451.

Hughes, P.D.M., Mauquoy, D., Barber, K.E., Langdon, P.G., 2000. Mire development pathways and paleoclimatic records from a full Holocene peat archive at Walton Moss, Cumbria, England. Holocene 10 (4), 465-479.

Ibáñez, J.J., Abdo, K., Balbo, A., Boix, J., Darwish, A., Himi, M., Iriarte, E., Lagüera, M., Nuñez, M.A., Regalado, E., Sabreen, E., Santana, J., Teira, L., Terradas, X., Zapata, L. 2009. Rapport Qarassa 2009. Mission syro-française de la léja, travaux de l'equipe espagnole, Damasc, Siria.

Ibañez, J.J., Abdo, A., Arranz, A., Balbo, A., Boix, J., Bshesh, M., Gourichon, L., Iriarte, E., Lagüera, M., Nuñez, M.A., Ortega, D., Regalado, E., Santana, J., Teira, L., Terradas, X., Zapata, L. 2010a: Rapport Qarassa 2010. Mission syro-Française de la Léja. Travaux de l' equipe espagnole, Damasc, Siria.

Ibañez, J.J., Balbo, A., Braemer, F., Gourichon, L., Iriarte, E., Santana, J., Zapata, L. 2010b. The early PPNB levels of Tell Qarassa North (Sweida, southern Syria). Antiquity 84 , issue 325 .

Ibáñez, J.J., González-Urquijo, J.E., Braemer, F. 2014. The human face and the origins of the Neolithic: the carved bone wand from Tell Qarassa North, Syria. Antiquity 88, issue 81.

Janis, C. 2008. An evolutionary history of browsing and grazing ungulates. In: Szaro, R., Johnston, D.W. (Eds.), Biodiversity in Managed Landscapes: Theory and Practice. Springer, 21-43. 
403

404

405

406

Kaniewski, D., Van Campo, E., Paulissen, E., Weiss, H., Bakker, J., Rossignol, I., Van Lerberghe, K., 2011. The medieval climate anomaly and the little Ice Age in coastal Syria inferred from pollen-derived palaeoclimatic patterns. Glob. Planet. Change 78, 178-187.

Katz, O., Cabanes, D., Weiner, S., Maeir, A.M., Boaretto, E., Shahack-Gross, R. 2010. Rapid phytolith extraction for analysis of phytolith concentrations and assemblages during an excavation: an application at Tell es-Safi/Gath, Israel. J Archaeol Sci 37, 1557-1563.

Köhler-Rollefson, I. 1988. The aftermath of the Levantine Neolithic Revolution in the light of ecological and ethnographic evidence. Paléorient 14, 87-93.

Köhler-Rollefson, I., Rollefson, G. 1990. The impact of Neo- lithic subsistence strategies on the environment: The case of 'Ain Ghazal, Jordan. In: Bottema S., Entjes-Nieborg, G., Van Zeist, W. (Eds.), Man's Role in the Shaping of the Eastern Mediterranean Landscape. Balkema, 3-14.

Kuijt, I., Goring-Morris, N.A. 2002. Foraging, Farming, and Social Complexity in the Pre-Pottery Neolithic of the Southern Levant: A Review and Synthesis. World Archaeol 164, 361-440.

Laggunt, D., Almogi-Labin, A., Bar-Matthews, M., Weistein-Evron, M., 2011. Vegetation and climate changes in the south eastern Mediterranean during the Last Glacial Interglacial cycle (86 ka): new marine pollen record. Quat. Sci. Rev. 30, 3960-3972.

Leavitt, S.W., Long, A., 1986. Stable-carbon isotope variability in tree foliage and wood. Ecology 67, 1002-1010.

Lemcke, G., Sturm, M., 1997. 180 and trace element measurements as proxy for the reconstruction of climate changes at Lake Van (Turkey): preliminary results. In: Nüzher Dalfes, H., Kukla, G., Weiss, H. (Eds.), Third Millenium BC Climate Change and Old World Collapse, NATO ASI Series, vol. I (49). Springer, Berlin, Heidelberg, pp. 653-678. 
Liphschitz, N., Noy, T., 1991. Vegetational landscape and the macroclimate of the gilgal region during the natufian and pre-pottery neolithic a. J. Israel Prehist. Soc. 24, 59-63.

Liphschitz, N., 1997. Wood remains from two PPNB sites: horvat galil and Nahal Beset. Tel Aviv 24, 237-239.

Liphschitz, N., 2010. Wood remains from the gilgal sites. In: Bar-Yosef, O., GoringMorris, A.N., Gopher, A. (Eds.), Gilgal: Early Neolithic Occupation in the Lower Jordan Valley, the Excavations of Tamar Noy. Oxbow Books, Oxford and Oakville, pp. 259-262.

Liphschitz, N., Biger, G., 1992. Israel: historical timber trade in the Levant: the use of Cedrus libani in construction of buildings in Israel from ancient times to the early twentieth century. In: Bartholin, T.S., Berglund, B.E., Eckstein, D., Schweingruber, F.H. (Eds.), Tree Rings and Environment. Proceedings of the International Dendrochronological Symposium, Ystad, South Sweden 3-9 September 1990. Lundqua Report, Lund, vol. 34, pp. 202-206.

Litt, T., Krastel, S., Sturm, M., Kipfer, R., Örcen, S., Heumann, G., Franz, S.O., Ülgen, U.B., Niessen, F. 2009. Lake Van Drilling Project 'PALEOVAN', Interna- tional Continental Scientific Drilling Program (ICDP): results of a recent pre-site survey and perspectives. Quat Sci Rev 28, 1555-1567.

Litt, T., Anselmetti, F.S., Baumgarten, H., Beer, J., Çagatay, N., Cukur, D., Damci, E., Glombitza, C., Haug, G., Heumann, G., Kallmeyer, J., Kipfer, R., Krastel, S., Kwiecien, O., Meydan, A.F., Orcen, S., Pickarski, N., Randlett, M.-E., Schmincke, H.-U., Schubert, C.J., Strum, M., Sumita, M., Stockhecke, M., Tomonaga, Y., Vigliotti, L., Wonik, T., The PALEOVAN Scientific Team, 2012. 500,000 years of environmental history in Eastern Anatolia: the PALEOVAN drilling project. Sci. Drill. J. 14, 18-29.

Litt, T., Pickarski, N., Heumann, G., Stockhecke, M., Tzedakis, P.C., 2014. A 600,000 year long continental pollen record from Lake Van, eastern Anatolia (Turkey). Quat. Sci. Rev. 104, 30-41. 
López-Sáez, J.A., López-Merino, L. 2005. Precisiones metodológicas acerca de los

443 indicios paleopalinológicos de agricultura en la Prehistoria de la Península Ibérica. 444 Portugalia 26, 53-64.

445

López-Sáez, J.A., López-Merino, L. 2007. Coprophilous fungi as a source of information 447 of anthropic activities during the Prehistory in the Amblés Valley (Ávila, Spain): the archaeopalynological record. Rev Esp Micropal 39, 103-116.

López-Sáez, J.A., van Geel, B., Martín-Sanchez, M., 2000. Aplicacion de los microfosiles no polínicos en Palinología Arqueologica. In: Oliveira Jorge, V., Coord. (Eds.), Contributos das $\mathrm{Ci}^{\wedge}$ encias e das Technologias para a Arqueologia da Península Iberica. Actas do 3 Congresso de Arqueologia Peninsular, vol. IX, Vila-Real, Portugal, setembro de 1999, ADECAP, Porto, pp. 11-20.

455

López-Sáez, J.A., López-García, P., Burjachs, F. 2003. Arqueopalinología: Síntesis crítica. Pollen 12, 5-35.

López-Sáez, J.A., van Geel, B., Farbos-Texier, S., Diot, M.F. 1998. Remarques paléoécologiques à propos de quelques palynomorphes non-polliniques provenant de sédiments quaternaires en France. Rev Paléobiol 17, 445-459.

462

Madella, M., Alexandre, A., Ball, T.B., ICPN Working Group 2005. International Code for Phytolith Nomenclature 1.0. Ann Bot 96, 253-260.

Magny, M., Begeot, C., Guiot, J., Peyron, O., 2003. Contrasting patterns of hydrological changes in Europe in response to Holocene climate cooling phases. Quat. Sci. Rev. 22, 1589-1596.

469

Maher, L., Banning, E.B., Chazan, M. 2011. Oasis or Mirage? Assessing the Role of

471 Abrupt Climate Change in the Prehistory of the Southern Levant. Cam Archaeol J 21(1), $4721-29$. 
Marguerie, D., Hunot, J.Y., 2007. Charcoal analysis and dendrology: data from archaeological sites in north-western France. J. Archaeol. Sci.. 34, 1417-1433.

Masi, A., Sadori, L., Banechi, I., Siani, A.M., Zanchetta, G. 2013. Stable isotope analysis of archaeological oak charcoal from eastern Anatolia as a marker of mid-Holocene climate change. Plant Biol 15, 83-92.

Mayewski, P., Rohling, E.E., Stager, J.C., Karl e, W., Maasch, K., Meeker, L.D., Meyerson, E.A., Gasse, F., van Kreveld, S., Holmgren, K., Lee-Thorp, J., Rosqvist, G., Rack, F., Staubwasser, M., Schneider, R., Steig, E.J., 2004. Holocene climate variability. Quat. Res. 62, 243-255.

Meadows, J. 2005. The Younger Dryas episode and the radiocarbon chronologies of the Lake Huleh and Ghab Valley pollen diagrams, Israel and Syria. The Holocene 15(4), 631636.

Meadows, D.H., 2009. Thinking in Systems. Earthscan, London. Miebach, A., Niestrath, P., Roeser, P., Litt, T., 2015. Impacts of climate and humans on the vegetation in NW Turkey: palynological insights from Lake Iznik since the Last Glacial. Clim. Past. Discuss. $11,5157-5201$.

Migowski, C., Stein, M., Prasad, S., Negendank, J.F.W., Agnon, A., 2006. Holocene climate variability and cultural evolution in the Near East from the Dead Sea sedimentary record. Quat. Res. 66, 421-431.

Moore, P.D., Webb, J.A., Collinson, M.E. 1991. Pollen analysis. Blackwell.

Mouterde, P. 1953. La flore du Djebel Druze. Université Saint Joseph de Beyrouth.

Mulholland, S.C., Rapp, J.r.G. 1992. A morphological classification of grass silica-bodies. In: Rapp, Jr.G., Mulholland, S.C. (Eds.), Phytolith Systematics: Emerging Issues, Advances in Archaeological and Museum Science. Plenum Press, 65-89.

Neef, R. 2003. Overlooking the steppe forest: preliminary report on the botanical remains 
from early Neolithic Göbekli Tepe (southern Turkey). Neo-Lithics 2, 13-15.

Neef, R., 2004a. PPNB settlements: vegetation and climate. A comparison between PPNB 'ain ghazal and Basta. In: Bienert, H.D., Gebel, H.G.K., Neef, R. (Eds.), Central Settlements in Neolithic Jordan. ex Oriente, Berlin, pp. 289-299.

Neef, R., 2004b. Vegetation and plant husbandry. In: Nissen, H.J., Muheisen, M., Gebel, H.G.K. (Eds.), Basta I: the Human Ecology. ex Oriente, Berlin, pp. 187-218.

Neumann, K., Schoch, W., Détienne, P., Schweingruber, F.H. 2001. Woods of the Sahara and the Sahel. Paul Haupt.

Neumann, F.H., Schölzel, C., Litt, T., Hense, A., Stein, M. 2007. Holocene vegetation and climate history of the northern Golan heights (Near East). Veg Hist Archaeobot 16(4), 329-346.

Nguyen-Queyrens, A., Ferhi, A., Loustau, D., Guehl, J.M., 1998. Within-ring delta C-13 spatial variability and interannual variations in wood cellulose of two contrasting provenances of Pinus pinaster. Can. J. For. Res. Rev. Can. de Recherche For. 28, 766-773.

Pessin, H. 2004. Stratégies d'approvisionnement et utilisation du bois dans le Moyen Euphrate et la Damascène. Approche anthracologique comparative de sites historiques et prehistoriques. Ph.D. thesis, Université de Paris.

Peters, J., van den Driesch, A., Helmer, D. 2005. The Upper Euphrates-Tigris Basin: Cradle of agro-pastoralism? In: Vigne, J.-D., Peters, J., Helmer, D. (Eds.), The First Steps of Animal Domestication: New Archaeozological Approaches. Oxbow Books, Oxford, 4148.

Piperno, D.R. 1988. Phytolith Analysis: An Archaeological and Geological Perspective. Academic Press.

Piperno, D.R. 2006. Phytoliths: A comprehensive guide for archaeologists and paleoecologists. AltaMira Press. 
543 Portillo, M., Kadowaki, S., Nishiaki, Y., Albert, R.M. 2014. Early Neolithic household 544 behavior at Tell Seker al-Aheimar (Upper Khabur, Syria): a comparison to 545 ethnoarchaeological study of phytoliths and dung spherulites. J Archaeol Sci 42, 107-118.

546

547 Portillo, M., Llergo, Y., Ferrer, A., Albert, R.M. 2017. Tracing microfossil residues of 548 cereal processing in the archaeobotanical record: an experimental approach. Veget Hist 549 Archaeobot. 26, 59-74.

550

551

Pross, J., Kotthoff, U., Müller, U.C., Peyron, P., Dormoy, I., Schmiedl, G., Kalaitzidis, S., 552 Smith, A.M. 2009. Massive perturbation in terrestrial ecosystems of the Eastern 553 Mediterranean region associated with the 8.2 kyr B.P. climatic event. Geology 37, 887554 890.

555

556 Rambeau, M.C. 2010. Palaeoenvironmental reconstruction in the southern Levant: 557 Synthesis, challenges, recent developments and perspectives. Philos T the Roy Soc A 368, 558 $5225-5248$.

559

560

Rasmussen, S.O., Vinther, B.M., Clausen, H.B., Andersen, K.K., 2007. Early Holocene 561 climate oscillations recorded in three Greenland ice cores. Quat. Sci. Rev. 26, 1907-1914.

562

563 Reille, M. 1999. Pollen et spores d'Europe et d'Afrique $d u$ Nord, $2^{\text {nd }}$ edn. Laboratoire de 564 Botanique Historique et Palynologie.

565

566

Riehl, S., Asouti, E., Karakaya, D., Starkovich, B.M., Zeidi, M., Conard, N.J., 2015.

Resilience at the transition to agriculture: the long-term landscape and resource development at the aceramic neolithic tell site of chogha golan (Iran). Biomed. Res. Int. 122. Article ID 532481.

570

Roberts, N. 2002. Did prehistoric landscape management retard the postglacial spread of woodlands in south-west Asia?. Antiquity 76, 1002-1010.

Roberts N., Wright H.E. 1993. Vegetational, lake-level and climatic history of the Near 575 East and Southwest Asia. In Wright, H.E., Kutzbach, J.E., Webb, T., Ruddiman, W.F., 576 Street-Perrott, F.A., Bartlein, P.J., editors, Global Climates Since the Last Glacial 
579 Roberts, N., Reed, J., Leng, M.J., Kuzucuoglu, C., Fontugne, M., Bertaux, J., Woldring, 580 H., Bottema, S., Black, S., Hunt, E., Karabiyikoglu, M., 2001. The tempo of Holocene 581 climatic change in the eastern Mediterranean region: new highresolution crater-lake 582 sediment data from central Turkey. Holocene 11, 719-734.

583

584 Roberts, N., Rosen, A.M. 2009. Diversity and complexity in early farming communities of 585 Southwest Asia: new insights into the economic and environmental basis of Neolithic 586 Çatalhöyük. Curr Anthropol 50, 393-402.

587

588 Robinson, S., Black, S., Sellwood, B., Valdes, P. 2006. A review of palaeoclimates and 589 palaeoenvironments in the Levant and Eastern Mediterranean from 25,000 to 5000 years 590 BP: Setting the environmental background for the evolution of human civilisation, Quat 591 Sci Rev 25, 1517-1541.

592

593

Roitel, V. 1997. Végétation et action de l'homme du Natoufien au Néolithique acéramique 594 dans le Haut-Euphrate syrien. Ph.D thesis, Université de Montpellier II.

Rollefson, G.O., Köhler-Rollefson, I. 1989. The collapse of Early Neolithic settlements in the southern Levant. In: Hershkovitz I. (Ed.), People and culture in change: Proceedings of the Second Symposium on Upper Palaeolithic, Mesolithic and Neolithic Populations of Europe and the Mediterranean Basin, British Archaeological Reports International Series 508(i), Oxford, 73-89.

601

Rosen, A.M. 1992. Preliminary identification of silica skeletons from Near Eastern archaeological sites: an anatomical approach. In: Rapp, Jr.G., Mulholland, S.C. (Eds.), Phytolith Systematics: Emerging Issues, Advances in Archaeological and Museum 605 Science. Plenum Press, 129-147.

606

607

Rosen, A.M. 2007. Civilizing Climate: Social Responses to Climate Change in the Ancient 608 Near East. Altamira. 
Rossignol-Strick, M. 1995. Sea-land correlation of pollen records in the Eastern Mediterranean for the Glacial-Interglacial transition: biostratigraphy versus radiometric time-scale. Quat Sci Rev14, 893-915.

Rossignol-Strick, M. 1997. Paléclimat de la Mediterranee orientale et de l'Asie du sudouest de 15000 d 6000 BP. Paléorient 23, 175-186.

619

620

Rossignol-Strick, M. 1999. The Holocene climatic optimum and pollen records of sapropel 621 1 in the Eastern Mediterranean, 9000-6000 BP. Quat Sci Rev 18, 515-530.

622

Santana, J., Velasco, J., Ibanez, J.J., Braemer, F. 2012. Crania with mutilated facial skeletons: a new ritual treatment in an early Pre-Pottery Neolithic B cranial cache at Tell Qarassa North (South Syria). Am J Phys Anthropol 149 (2), 205-216.

626

627

Santana, J. Velasco, J., Balbo, A., Iriarte, E., Zapata, L., Teira, L., Nicolle, C., Braemer, F., 628 Ibáñez, J.J. 2015. Interpreting a ritual funerary area at the Early Neolithic site of Tell 629 Qarassa North (South Syria, late 9th millennium BC). J Anthropol Archaeol 37, 112-127.

Semerci, A., 2005. Fifth year performance of morphologically graded Cedrus libani 632 seedlings in the Central Anatolia Region of "Turkey”. Turk. J. Agric. For. 29, 483-491.

633

Schiebel, V., 2013. Vegetation and Climate History of the Southern Levant during the Last 635 30,000 Years Based on Palynological Investigation. PhD Thesis. MathematischNaturwissenschaftlichen Fakult.t, Rheinischen Friedrich- Wilhelms- Universit.t. Available at: http://hss.ulb.uni-bonn.de/2013/3270/3270.htm.

Schleser, G.H., 1992. Delta C-13 pattern in a forest tree as an indicator of carbon transfer 640 in trees. Ecology 73, 1922-1925.

641

642 Schwab, M.J., Neumann, F., Litt, T., Negendank, J.F.W., Stein, M., 2004. Holocene 643 palaeoecology of the golan heights (near east): investigation of lacustrine sediments from 644 Birkat Ram crater lake. Quat. Sci. Rev. 23, 1723-1731. 
646 Schweingruber, F.H. 1990. Anatomy of European woods. An atlas for the identification of

647 European trees, shrubs and dwarf shrubs. Paul Haupt.

648

649 Simmons, A. H. 2000. Villages on the edge: regional settlement change and the end of the 650 Levantine Pre-Pottery Neolithic. In: Kuijt, I. (Ed.), Life in Neolithic Farming 651 Communities, Kluwer Academic, 211-230.

652

653 Skarpe, C., Hester, A. 2008. Plant traits, browsing and grazing herbivores, and vegetation 654 dynamics. In: Gordon, I.J., Prins, H.H.T. (Eds.), The Ecology of Browsing and Grazing, 655 Springer, 217-261.

656

657 Smart, T.L., Hoffman, E. 1988. Environmental interpretation of Archaeological Charcoal. 658 In: Hastorf, C.A., Popper, V.S. (Eds.), Current Palaeoethnobotany Analytical Methods 659 and Cultural Interpretations of Archaeological Plant remains. University of Chicago 660 Press, 167-205.

661

Stevens, L.R., Wright, H.E. Jr., Ito, E. 2001. Proposed changes in seasonality of climate 663 during the Late-glacial and Holocene at Lake Zeribar, Iran. The Holocene 11, 747-756.

664

665

Stevens, L.R., Ito, E., Schwalb, A., Wright, H.E. Jr. 2006. Timing of atmospheric 666 precipitation in the Zagros Mountains inferred from a multi-proxy record from Lake 667 Mirabad, Iran. Quat Res 66, 494-500.

668

Tanno, K.I., Willcox, G. 2012. Distinguishing wild and domesticated wheat and barley 670 spikelets from early Holocene sites in the Near East. Veg Hist Archaeobot 21, 107-115.

672 Tans, P.P., Mook, W.G., 1980. Past atmospheric CO2 levels and the 13C/12C ratios in tree 673 rings. Tellus 32, 268-283.

674

Tchernov, E., Horwitz, L.K. 1990. Herd management in the past and its impact on the 676 landscape of the southern Levant. In: Bottema, S., Entjes-Nieborg, G., van Zeist, W.

677 (Eds.), Man's Role in the Shaping of Eastern Mediterranean Landscape. Balkema, 207678 218 . 
680 Traboulsi, M. 2013. Les précipitations dans les marges arides du Proche-Orient: l'exemple

681 du bassin versant du Yarmouk. Hannon, revue de géographie libanaise, 26, 7-39.

682

683 Tsartsidou, G., Lev-Yadun, S., Albert, R.M., Miller-Rosen, A., Efstratiou, N., Weiner, S. 684 2007. The phytolith archaeological record: strengths and weaknesses based on a 685 quantitative modern reference collection from Greece. J Archaeol Sci 34, 1262-1275.

686

687 Turner, R., Roberts, N., Eastwood, W.J., Jenkins, E., Rosen, A. 2010. Fire, climate and the 688 origins of agriculture: micro-charcoal records of biomass burning during the last 689 glacialeinterglacial transition in Southwest Asia. J Quat Sci 25, 371-386.

690

691 Twiss, P.C. 1992. Predicted world distribution of $\mathrm{C}_{3}$ and $\mathrm{C}_{4}$ grass phytoliths. In: Rapp, 692 Jr.G., Mulholland, S.C. (Eds.), Phytolith Systematics: Emerging Issues, Advances in 693 Archaeological and Museum Science. Plenum Press, 113-128.

694

695

Twiss, P.C., Suess, E., Smith, R.M. 1969. Morphological classification of grass phytoliths. 696 Soil Science Society of America Proceedings 33, 109-115.

697

van Geel, B. 2001. Non-pollen palynomorphs. In: Smol, J.P., Birks, H.J.B., Last, W.M., 699 (Eds.), Tracking environmental change using lake sediments, vol. 3, Terrestrial, algal, and siliceous indicators. Kluwer, Dordrecht, 99-119.

701

van Geel, B., Buurman, J., Brinkkemper, O., Schelvis, J., Aptroot, A., van Reenen, G., Hakbijl, T. 2003. Environmental reconstruction of a Roman Period settlement site in Uitgeest (The Netherlands), with special reference to coprophilous fungi. J Archaeol Sci $30,873-883$.

van Zeist, W., Timmers, R.W., Bottema, S. 1970. Studies of modern and Holocene pollen precipitation in southeastern Turkey. Palaeohistoria 14, 19-39. 
van Zeist, W., Woldring, H. 1978. A postglacial pollen diagram from Lake Van in East Anatolia. Rev Palaeobot Palyno 26, 249-276.

van Zeist, W., Bottema, S. 1991. Late Quaternary Vegetation of the Near East. Dr Ludwig Reichert Verlag, Wiesbaden.

van Zeist, W., Baruch, U., Bottema, S. 2009. Holocene palaeoecology of the Hula area, northeastern Israel. In: Kaptijn, W., Lucas, P. (Eds.), Archaeological and Related Essays on the Jordan Valley in Honor of Gerrit van der Kooij on the Occasion of his 65th Birthday. A Timeless Vale. Leiden University Press, 29-64.

van Zeist, W., Smith, P.E.L., Palfenier-Vegter, R.M., Suwijn, M., Casparie, W.A., 1984.

An archaeobotanical study of ganj dareh tepe, Iran. Palaeohistoria 26, 201-224.

Vernet, J.L. 2001. Guide d'identification des charbons de bois préhistoriques et récents. CNRS Editions, Paris.

Vigne, J.-D. 2013. Domestication process and domestic ungulates: new observations from Cyprus. In: Colledge, S., Dobney, K., Manning, K., Shennan, S. (Eds.), The Origins and Spread of Domestic Animals in Southwest Asia and Europe. Publications of the Institute of Archaeology, University College, London, West Coast Press, Walnut Creek (CA), 115128.

Wasylikowa, K., Witkowski, A., Walanus, A., Hutorowicz, A., Alexandrowicz, S.W., Langer, J.J. 2006. Palaeolimnology of Lake Zeribar, Iran, and its climatic implications. Quat Res 66(3), 477-493.

Weninger, B., Clare, L., Rohling, E.J., Bar-Yosef, O., Böhner, U., Budja, M., Bundschuh, M., Feurdean, A., Gebel, H.G., Jöris, O., Linstädter, J., Mayewski, P., Mühlenbruch, T., Reingruber, A., Rollefson, G., Schyle, D., Thissen, L., Todorova, H., Zielhofer, C. 2009. The impact of rapid climate change on prehistoric societies during the Holocene in the eastern Mediterranean. Documenta Praehistorica 367-459.

Western, A.C., 1983. Appendix F. Catalogue of identified charcoal samples. In: Kenyon, 
K., Holland, T.A. (Eds.), Excavation at Jericho. Volume 5: the Pottery Phases of the Tell and Other Finds. British School of Archaeology in Jerusalem, London, pp. 770-773.

Wick, L., Lemcke, G., Sturm, M. 2003. Evidence of Lateglacial and Holocene climatic change and human impact in eastern Anatolia: High-resolution pollen, charcoal, isotopic and geochemical records from the laminated sediments of Lake Van, Turkey. The Holocene 13, 665-675.

Willcox, G. 1990. Charcoal remains from Tepe Abdul Hosein. In: Pullar, J. (Ed.), Tepe Abdul Hosein: A Neolithic site in Western Iran Excavations 1978. British Archaeological Reports International Series 563, 233-227.

Willcox, G. 1991. Cafer Höyük (Turquie): Les Charbons de bois Neolithiques. Cahiers de l'Euphrate (5-6), 139-150.

Willcox, G. 1999. Charcoal analysis and Holocene vegetation history in southern Syria. Quat Sci Rev 18(4-5), 711-716.

Willcox, G., 2005. The distribution, natural habitats and availability of wild cereals in relation to their domestication in the Near East: multiple events, multiple centres. Veg. Hist. Archaeobo. 14 (4), 534-541.

Willcox, G., Fornite, S., Herveux, L., 2008. Early Holocene cultivation before domestication in northern Syria'. Veg. Hist. Archaeobot. 17 (3), 313-325.

Wright, H.R. Jr., Thorpe, J.L. 2003. Climatic change and the Origins of agriculture in the Near East. In: Mackay, A., Battarbee, R., Birks, J., Oldfield, F. (Eds.), Global Change in the Holocene. Arnold, 49-62.

Yasuda, Y., Kitagawa, H., Nakagawa, T. 2000. The earliest record of major anthropogenic deforestation in the Ghab Valley, Syria: a palynological study. Quat Int 73(74), 127-136.

Zeder, M. 2011. The origins of agriculture in the Near East. Curr Anthropol 54(S4), S221S235. 
782 Zeder, M. 2015. Core questions in domestication research. Proc Natl Acad Sci USA 783 112(11), 3191-3198.

784

785 Zohary, M. 1973. Geobotanical foundations of the Middle East. Stuttgart, G Fischer, Swet 786 and Zeitlinger, Amsterdam.

787

788 Zohary, D., Hopf, M., Weiss, E., 2012. Domestication of Plants in the Old World. $4^{\text {th }}$ 789 Edition. Oxford University Press, Oxford.

790 